Prepared in cooperation with Texas A\&M University-Corpus Christi

\title{
Grassland Birds Wintering at U.S. Navy Facilities in Southern Texas
}

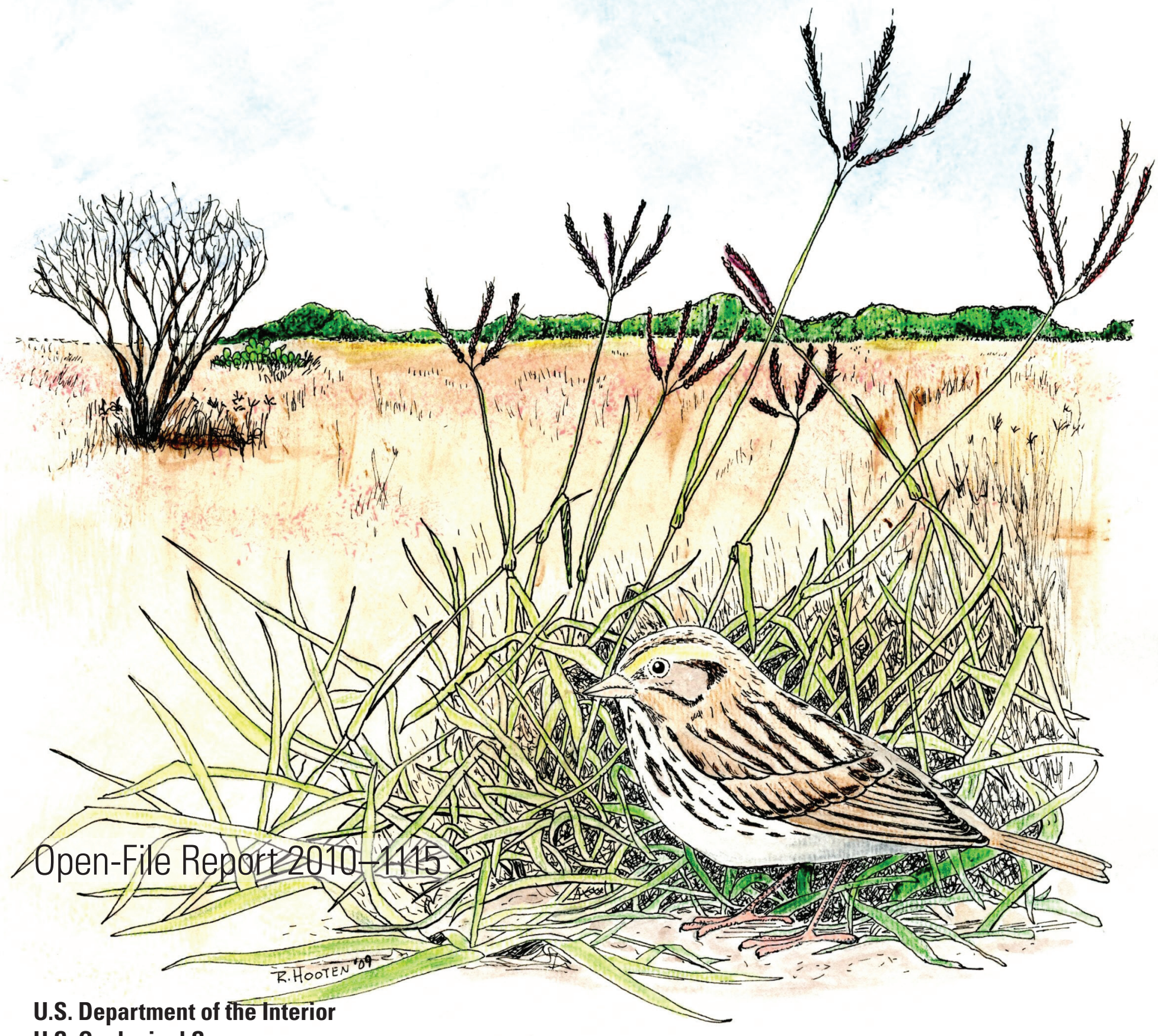

U.S. Geological Survey 


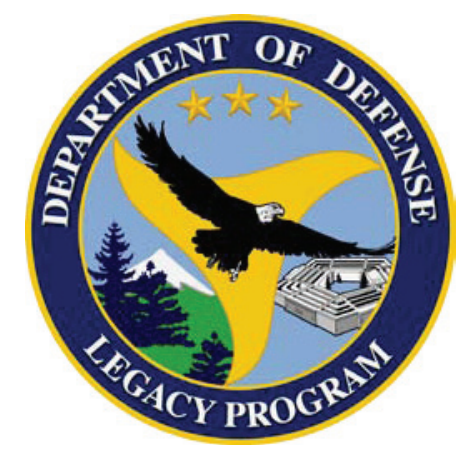

\section{Department of Defense Legacy Resource Management Program}

PROJECT NUMBER 07-189

\section{Grassland Birds Wintering at U.S. Navy Facilities in Southern Texas}

Marc C. Woodin, Mary Kay Skoruppa, Bryan D. Pearce, Amanda J. Ruddy, and Graham C. Hickman 


\section{Grassland Birds Wintering at U.S. Navy Facilities in Southern Texas}

By Marc C. Woodin, Mary Kay Skoruppa, Bryan D. Pearce, Amanda J. Ruddy, and Graham C. Hickman

Prepared in cooperation with Texas A\&M University-Corpus Christi

Open-File Report 2010-1115

U.S. Department of the Interior

U.S. Geological Survey 


\title{
U.S. Department of the Interior \\ KEN SALAZAR, Secretary \\ U.S. Geological Survey \\ Marcia K. McNutt, Director
}

\section{U.S. Geological Survey, Reston, Virginia: 2010}

\author{
For more information on the USGS — the Federal source for science about the Earth, its natural and living resources, \\ natural hazards, and the environment, visit http://www.usgs.gov or call 1-888-ASK-USGS \\ For an overview of USGS information products, including maps, imagery, and publications, \\ visit http://www.usgs.gov/pubprod \\ To order this and other USGS information products, visit http://store.usgs.gov
}

\begin{abstract}
Any use of trade, product, or firm names is for descriptive purposes only and does not imply endorsement by the U.S. Government.

Although this report is in the public domain, permission must be secured from the individual copyright owners to reproduce any copyrighted materials contained within this report.
\end{abstract}

Suggested citation:

Woodin, M.C., Skoruppa, M.K., Pearce, B.D., Ruddy, A.J., and Hickman, G.C., 2010, Grassland birds wintering at U.S. Navy facilities in southern Texas: U.S. Geological Survey Open-File Report 2010-1115, 48 p. with app. 


\section{Acknowledgments}

This project was funded in part by the Legacy Resource Management Program, U.S. Department of Defense. Chris Eberly, Department of Defense Partners in Flight Program, was instrumental in fostering this research. The authors are indebted to Navy Resource Managers Rich Riddle, Mike Hilger, and Sandy Maynard for coordinating research with the U.S. Navy. The authors also are grateful to Chris Cherniss, Eddie Earwood, James Stockton, Norma Barrera, Cesar Cavazos, Arnie DeLeon, Rodney Martinez, Jesse Rodriguez, Nick Briseno, Amy Field, and the staff of Naval Air Station-Corpus Christi (NASCC), Naval Auxiliary Landing Field Waldron, Naval Air Station-Kingsville, Naval Auxiliary Landing Field Orange Grove, and Escondido Ranch for their assistance in this project.

This research benefitted by many dedicated Texas A\&M University-Corpus Christi students who helped in the field. They include Aaron Baxter, Dree Kovacs Baxter, Kristie Landaberde Brink, Rafael Calderon, Amy Cox, Kelsey Feil, Loren Gallo, Travis Gallo, Jay Gardner, Jay Halepeska, Brent Koza, Larry Lloyd, Anna Lund, Gabriel Markoff, Erin McCarthy, Katherine Miller, Zane Ruddy, Damon Williford, and Lisa Winnett. The authors also are grateful for the long hours of lab and office assistance provided by Chesney Migl, Travis Gallo, Dree Kovacs Baxter, Larry Lloyd, Jay Halepeska, and Loren Gallo. Travis Gallo also undertook special training to provide airfield escorts for all aspects of field work at NASCC and Waldron.

Assistance with plant identification was provided by Robert Lonard, University of Texas-Pan American. Information and data on plant diversity in Texas were provided by Stephan L. Hatch, Texas A\&M University. Additional scientific expertise was provided by Gene Blacklock and David Newstead, Coastal Bend Bays \& Estuaries Program, Inc.; Jaimie Ingold, Laverne Cleveland, and Marcia Nelson, U.S. Geological Survey; David Grise', Joanna Mott, David Moury, and Kim Withers, Texas A\&M University-Corpus Christi; and Travis Gallo, Lady Bird Johnson Wildflower Center. The authors are indebted to Larry IgI, U.S. Geological Survey, Northern Prairie Wildlife Research Center and Alice Hempel, Texas A\&M University-Kingsville for reviewing this report. 



\section{Contents}

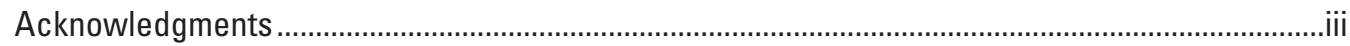

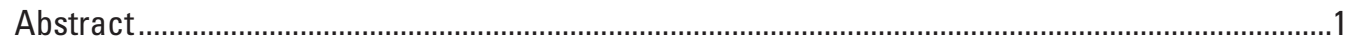

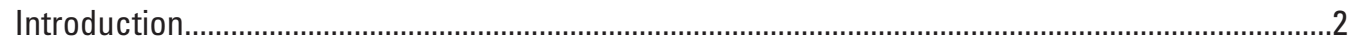

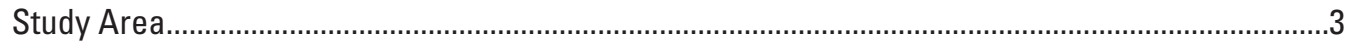

Gulf Coast and Inland Prairies of Texas ..............................................................................

U.S. Navy Facilities in Southern Texas................................................................................. 4

Birds in Native and Exotic Grasslands in Winter .......................................................................

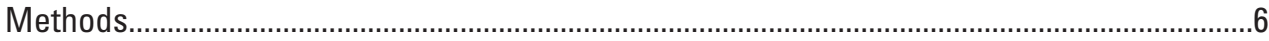

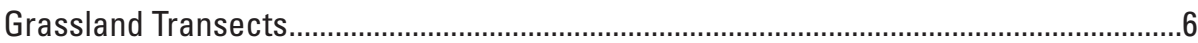

Winter Bird Surveys .......................................................................................................

Supplemental Information .............................................................................................

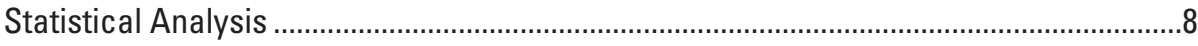

Results

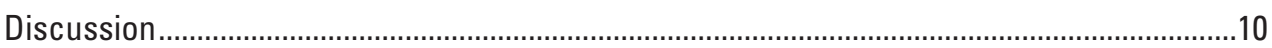

Structural and Floristic Characteristics of Native and Exotic Grasslands.....................................11

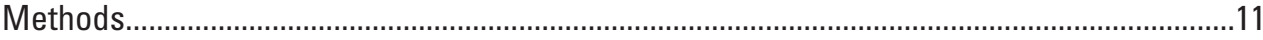

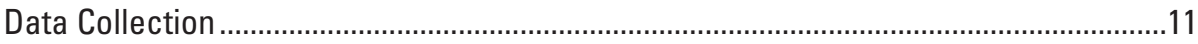

Statistical Analysis ................................................................................................. 12

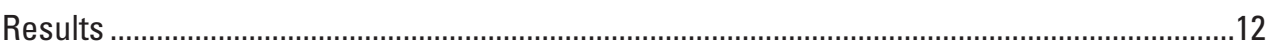

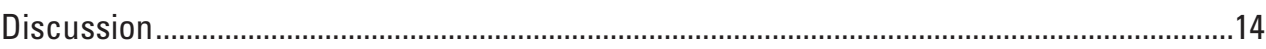

Components of Environmental Variation and Bird Use of Grasslands in Winter ..........................15

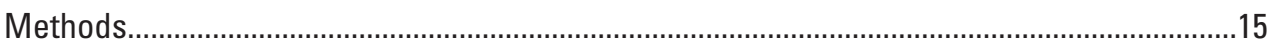

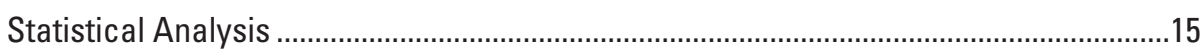

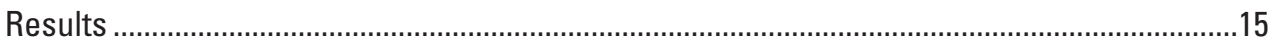

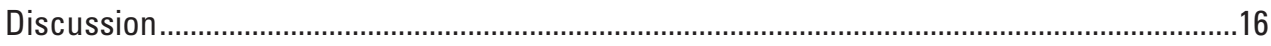

Insects and Arachnids in Native and Exotic Grasslands .............................................................17

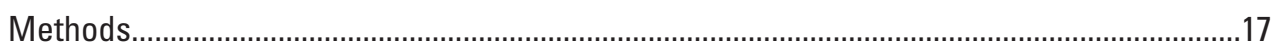

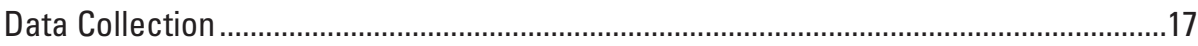

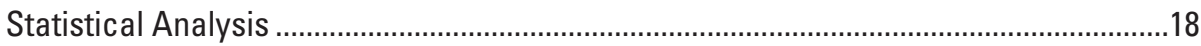

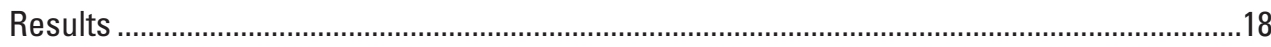

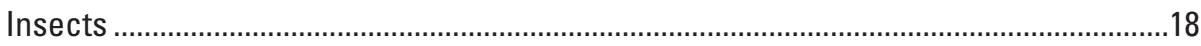

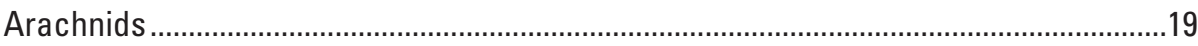

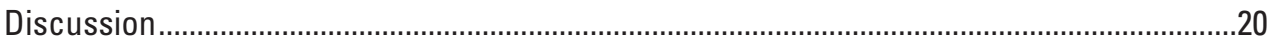

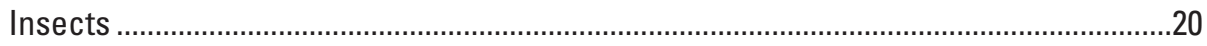

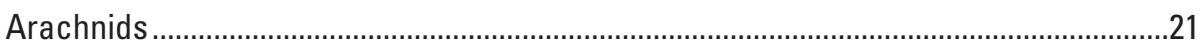

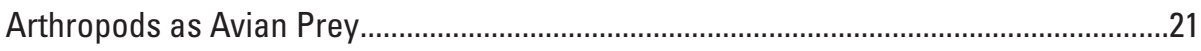

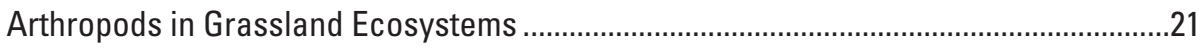

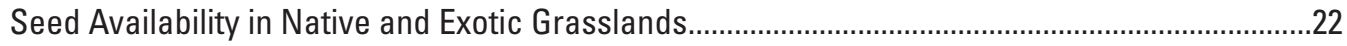

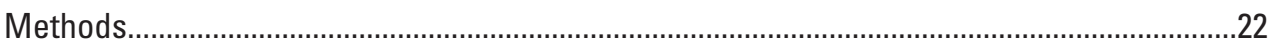

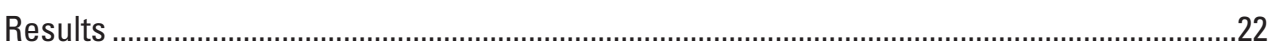

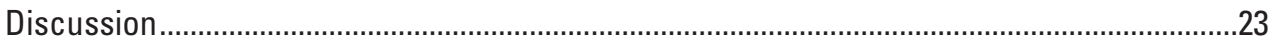


Responses of Birds and Rodents to Mowing and Controlled Burns of

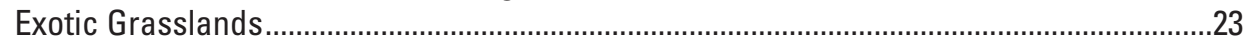

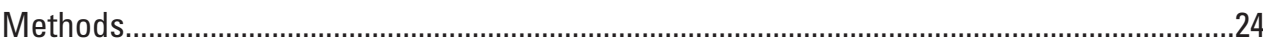

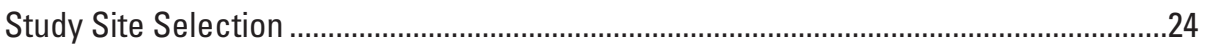

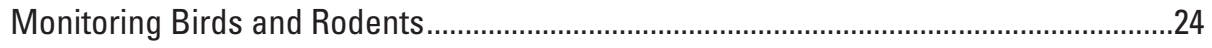

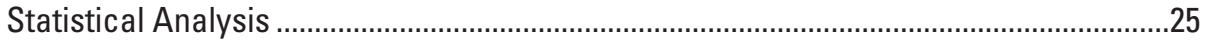

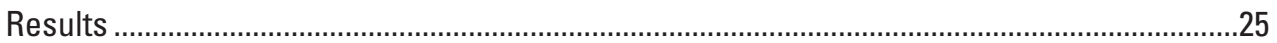

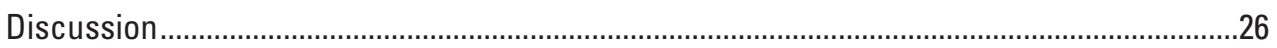

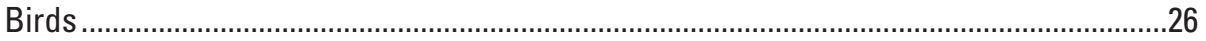

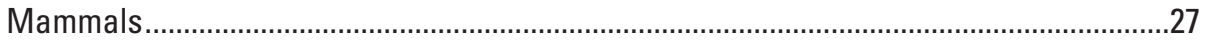

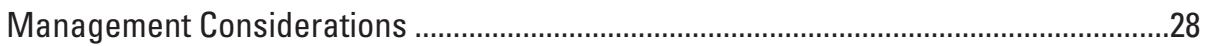

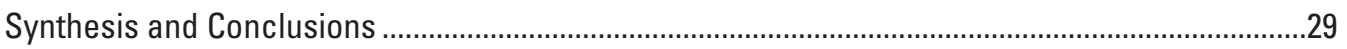

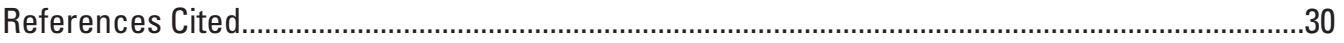

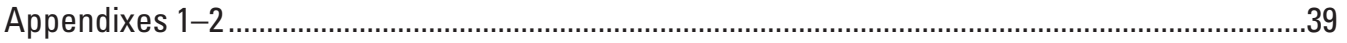

\section{Figures}

1. Map showing locations of five U.S. Navy facilities in southern Texas included in the study.

2. Illustration of technique for surveying wintering grassland birds in southern Texas.......7

3-9. Bar graphs showing-

3. Mean percent ground cover composition ( $\pm 1 S E$ ) of exotic and native grasslands of U.S. Navy lands in southern Texas. Means were calculated from data collected at 21 transects in exotic grasslands and 21 transects in native grasslands for 5 winters (2003-08), but not all transects were sampled in every year....

4. Relative abundances of insect orders within native and exotic grasslands in southern Texas, 2005-06

5. Mean numbers of insect families $( \pm 1 S E)$ in native and exotic grasslands by season in southern Texas, 2005-06

6. Relative abundances of arachnid families within native and exotic grasslands in southern Texas, 2005-06

7. Relative abundance of bird species during each sampling event at Naval Air Station-Kingsville, Kleberg County, Texas, November 2008-February 2009

8. Standardized rodent captures by treatment at Naval Air Station-Kingsville, Kleberg County, Texas, August 2008-June 2009.

9. Standardized rodent captures in $A$, control habitat, $B$, burned habitat, and $C$, mowed habitat for each sampling event at Naval Air Station-Kingsville, Kleberg County, Texas, August 2008-June 2009. 


\section{Tables}

1. Numbers of native and exotic grassland transects established at each of five U.S. Navy facilities in southern Texas during five winters, 2003-08.

2. Numbers of birds by species observed during 344 transect surveys in grasslands at five U.S. Navy facilities in southern Texas during five winters, 2003-08

3. Mammal species detected during field work at Escondido Ranch, McMullen County, Texas, during 2003-08

4. Amphibian and reptile species detected during field work at Escondido Ranch, McMullen County, Texas, 2003-08.

5. List of introduced grass species found on five U.S. Navy facilities in southern Texas, 2003-08, with their places of origin and approximate dates of arrival in the United States

6. Vegetation parameters for agricultural fields and mowed, native, and exotic grasslands sampled on five U.S. Navy facilities in southern Texas, 2003-08

7. Rainfall totals during the 8-month growing period (March-0ctober) at weather stations near five U.S. Navy facilities in southern Texas

8. Eigenvector loadings for variables for the first three principal components (PCs) in the principal components analysis of environmental variation in native grasslands in southern Texas in winter, 2003-08

9. Eigenvector loadings for variables for the first three principal components (PCs) in the principal components analysis of environmental variation in exotic grasslands in southern Texas in winter, 2003-08

10. Total number of insects by order and grassland type collected in southern Texas, March 2005-March 2006

11. Total number of arachnids by order, family, and grassland type collected in southern Texas, March 2005-March 2006

12. Mean abundance (number of birds per transect), standard error (in parentheses), and diversity of grassland birds by treatment.....

13. Mean abundance of grassland rodents, standard error (in parentheses), and diversity by treatment

14. Comparison of avian, vegetation, and arthropod characteristics between native and exotic grasslands in southern Texas

\section{Appendix Tables}

1. List of bird species (not all-inclusive) detected on U.S. Navy facilities in southern Texas, 2003-2008.

2. List of grasses (not all-inclusive) identified at U.S. Navy facilities in southern Texas, 2003-2008 


\section{Conversion Factors}

SI to Inch/Pound

\begin{tabular}{|c|c|c|}
\hline Multiply & By & To obtain \\
\hline \multicolumn{3}{|c|}{ Length } \\
\hline centimeter $(\mathrm{cm})$ & 0.3937 & inch (in.) \\
\hline meter $(\mathrm{m})$ & 3.281 & foot $(\mathrm{ft})$ \\
\hline kilometer (km) & 0.6214 & mile (mi) \\
\hline meter $(\mathrm{m})$ & 1.094 & yard (yd) \\
\hline \multicolumn{3}{|c|}{ Area } \\
\hline square meter $\left(\mathrm{m}^{2}\right)$ & 0.0002471 & acre \\
\hline hectare (ha) & 2.471 & acre \\
\hline square centimeter $\left(\mathrm{cm}^{2}\right)$ & 0.001076 & square foot $\left(\mathrm{ft}^{2}\right)$ \\
\hline square meter $\left(\mathrm{m}^{2}\right)$ & 10.76 & square foot $\left(\mathrm{ft}^{2}\right)$ \\
\hline square centimeter $\left(\mathrm{cm}^{2}\right)$ & 0.1550 & square inch $\left(\mathrm{ft}^{2}\right)$ \\
\hline hectare (ha) & 0.003861 & square mile $\left(\mathrm{mi}^{2}\right)$ \\
\hline \multicolumn{3}{|c|}{ Volume } \\
\hline milliliter $(\mathrm{mL})$ & 0.33814 & fluid ounce (fl oz) \\
\hline cubic meter $\left(\mathrm{m}^{3}\right)$ & 264.2 & gallon (gal) \\
\hline cubic meter $\left(\mathrm{m}^{3}\right)$ & 35.31 & cubic foot $\left(\mathrm{ft}^{3}\right)$ \\
\hline \multicolumn{3}{|c|}{ Mass and Density } \\
\hline $\operatorname{gram}(\mathrm{g})$ & 0.03527 & ounce, avoirdupois (oz) \\
\hline $\mathrm{g} / \mathrm{m}^{2}$ (gram per square meter) & 0.0002 & pound per square foot $\left(\mathrm{lb} / \mathrm{ft}^{2}\right)$ \\
\hline
\end{tabular}

Temperature in degrees Celsius $\left({ }^{\circ} \mathrm{C}\right)$ may be converted to degrees Fahrenheit $\left({ }^{\circ} \mathrm{F}\right)$ as follows:

${ }^{\circ} \mathrm{F}=\left(1.8 \mathrm{x}^{\circ} \mathrm{C}\right)+32$

Temperature in degrees Fahrenheit $\left({ }^{\circ} \mathrm{F}\right)$ may be converted to degrees Celsius $\left({ }^{\circ} \mathrm{C}\right)$ as follows:

${ }^{\circ} \mathrm{C}=\left({ }^{\circ} \mathrm{F}-32\right) / 1.8$ 


\title{
Grassland Birds Wintering at U.S. Navy Facilities in Southern Texas
}

\author{
By Marc C. Woodin', Mary Kay Skoruppa', Bryan D. Pearce ${ }^{2}$, Amanda J. Ruddy², and Graham C. Hickman²
}

\section{Abstract}

Grassland birds have undergone widespread decline throughout North America during the past several decades. Causes of this decline include habitat loss and fragmentation because of conversion of grasslands to cropland, afforestation in the East, brush and shrub invasion in the Southwest and western United States, and planting of exotic grass species to enhance forage production. A large number of exotic plant species, including grasses, have been introduced in North America, but most research on the effects of these invasions on birds has been limited to breeding birds, primarily those in northern latitudes. Research on the effects of exotic grasses on birds in winter has been extremely limited.

This is the first study in southern Texas to examine and compare winter bird responses to native and exotic grasslands. This study was conducted during a period of six years (2003-2009) on United States Navy facilities in southern Texas including Naval Air Station-Corpus Christi, Naval Air Station-Kingsville, Naval Auxiliary Landing Field Waldron, Naval Auxiliary Landing Field Orange Grove, and Escondido Ranch, all of which contained examples of native grasslands, exotic grasslands, or both. Data from native and exotic grasslands were collected and compared for bird abundance and diversity; ground cover, vegetation density, and floristic diversity; bird and vegetation relationships; diversity of insects and arachnids; and seed abundance and diversity. Effects of management treatments in exotic grasslands were evaluated by comparing numbers and diversity of birds and small mammals in mowed, burned, and control areas.

To determine bird abundance and bird species richness, birds were surveyed monthly (December-February) during the winters of 2003-2008 in transects (100 meter $\times 20$ meter) located in native and exotic grasslands distributed at all five U.S. Navy facilities. To compare vegetation in native and exotic grasslands, vegetation characteristics were measured during 2003-2008 in the same transects used for bird surveys and included five measures of ground cover, plus estimates of plant species richness, vegetation density (visual obstruction)

${ }^{1}$ U.S. Geological Survey, Columbia Environmental Research Center, Corpus Christi, Texas.

${ }^{2}$ Texas A\&M University-Corpus Christi, Corpus Christi, Texas. at two different heights, and shrub numbers. These data, plus seasonal rainfall, were then used to evaluate components of variation in native and exotic grasslands. Relations between total bird numbers and bird species richness with environmental variation in native and exotic grasslands were compared. To compare diversity of arthropods in native and exotic grasslands, insects and arachnids were collected using three different methodologies (standardized sweep-net, random sweep-net, and pitfall traps) during four seasons, (2005-2006), at Naval Air Station-Corpus Christi, Naval Auxiliary Landing Field Waldron, and Naval Air Station-Kingsville. To compare seed abundance and diversity between native and exotic grasslands, seeds were collected for two winters (2004-2006) at Naval Air Station-Corpus Christi and Naval Air StationKingsville. To evaluate effects of management on grassland vertebrates, abundance and diversity of birds and small mammals were estimated and compared in exotic grasses subjected to mowing, burning, or no active management (control) for one full year (2008-2009).

Observations were made of 1,044 birds of 30 species in grassland transects during five winters. The Savannah Sparrow (Passerculus sandwichensis) was the most common bird, which, with 644 detections, accounted for 63 percent of all individuals identified to species. Meadowlarks (Sturnella spp.) and Le Conte's Sparrows (Ammodramus leconteii) were the second (10 percent) and third ( 7 percent) most abundant bird species, respectively. Six of the seven most abundant species detected in grasslands were grassland species, and their numbers accounted for 87 percent of all birds, but 20 of the 30 species (67 percent) that used grasslands were not grassland species. Seven species observed in grassland transects during the study were Species of Conservation Concern: Le Conte's Sparrow, Sedge Wren (Cistothorus platensis), Grasshopper Sparrow (Ammodramus savannarum), Long-billed Curlew (Numenius americanus), Sprague's Pipit (Anthus spragueii), Cassin's Sparrow (Aimophila cassinii), and Loggerhead Shrike (Lanius ludovicianus). Native grasslands consistently supported greater bird species richness than exotic grasslands. In one winter, exotic grasslands supported more birds than native grasslands.

Native grasslands were determined to have more forb cover, more bare ground, and greater plant species richness than exotic grasslands, whereas exotic grasslands were 
characterized by more grass cover and relatively greater vegetation density during dry years. Not only did these individual measures differ between native and exotic grasslands, but components of variation also differed. In native grasslands, grass density and cover contributed more to variation, whereas in exotic grasslands, non-grass vegetation was a greater component of variation. Total bird numbers and bird species richness in native grasslands were related to the principal component that contained a measure of litter cover. Total bird numbers and bird species richness in exotic grasslands indicated no significant relationships with any of the principal components of variation.

The two most common insect orders in native grasslands were Hymenoptera and Coleoptera, which accounted for 42 percent of all insects. The two most common insect orders in exotic grasslands were Hemiptera and Homoptera, which accounted for about 80 percent of all insects. Insect family richness was greater in exotic grasslands than in native grasslands in two of four seasons. Proportions of arachnid families were similar in native and exotic grasslands, but arachnid family richness was greater in exotic grasslands than in native grasslands.

Abundance of seeds was greater in exotic than in native grasslands. However, seed diversity was greater in native grasslands than in exotic grasslands.

Among the three types of management (mowed, burned, and control) applied to exotic grasses, birds were most abundant in the mowed area. Sedge Wrens, however, were never encountered in mowed sites. Meadowlarks were similarly abundant in all treatments, but Le Conte's Sparrows were detected only in the control (unmanaged) area. Hispid cotton rats (Sigmodon hispidus) accounted for 93 percent of all rodent captures, with the number of captures peaking December through February. Hispid cotton rat numbers and total rodent numbers were greatest in control and pre-burn areas, and lowest in the mowed area. Mammal diversity, however, was greatest in the mowed habitat.

Native and exotic grasslands differed essentially in all categories (bird numbers and diversity, vegetation characteristics, components of variation, diversity of insects and arachnids, and seed abundance and diversity) used to measure and compare them. This indicates that fundamental ecosystem processes have been altered after native grasslands have undergone invasion and ultimate domination by exotic grass species. Future research in Texas grassland ecosystems is essential because: 1) Texas sustains more area in grasslands than any other state or province in the Central Flyway; 2) Texas serves as the winter destination or migration pathway for hundreds of species of birds, including winter residents and Neotropical migrants; 3) ecology, distribution, and numbers of grassland birds wintering in southern latitudes of the United States remains poorly understood; and 4) climate change threatens to further accelerate advances of invading grass species.

\section{Introduction}

Sharp population declines have been documented for many species of grassland birds across much of North America (Peterjohn and Sauer, 1999; Sauer and others, 2008). Most grassland bird species monitored by the North American Breeding Bird Survey (BBS) have experienced substantial declines between 1966 and 2007, (Sauer and others, 2008), and endemic grassland birds have exhibited the most consistent and dramatic declines of any group monitored by the North American BBS (Knopf, 1994; Peterjohn and Sauer, 1999). Impressive declines in grassland bird species have been demonstrated regionally as well, in the eastern United States (U.S.) (Askins, 1993), midwestern states (Herkert, 1995), in the western U.S. (Knopf, 1994), and in prairie grasslands of south-central Canada (Houston and Schmutz, 1999). Declining grassland bird numbers have been attributed primarily to habitat loss, degradation, and fragmentation because of conversion of grasslands to agricultural production, other landscape alterations associated with settlement, and afforestation (Knopf, 1994; Lloyd and others, 1998; Winter and Faaborg, 1999; Fritcher and others, 2004; Brennan and Kuvlesky, 2005).

An enhanced awareness of the plight of grassland birds in North America has resulted in a substantial increase in investigations on grassland bird species during the past two decades, but much of this attention has been directed at grassland birds on their breeding grounds (Vickery and others, 1999; Askins and others, 2007). In fact, Askins (1993) and Vickery and Herkert (2001), among others, have called for increased research on winter ecology and habitats of grassland birds to redress this overall imbalance. Despite this historical tilt toward studies on breeding birds, some notable exceptions exist. In the southwestern United States, in particular, a number of studies have focused on birds wintering in desert grasslands. During the 1970s and 1980s, a lengthy series of field studies of overwintering grassland birds in southern Arizona were used to evaluate and test theories of resource use and partitioning, species packing and coexistence, and population regulation (Pulliam and Mills, 1977; Pulliam and Parker, 1979; Pulliam, 1985; Pulliam and Dunning, 1987). More recently, research on wintering grassland birds in Arizona has shifted to more applied studies of the effects of land use and management activities (Bock and Bock, 1998; Kirkpatrick and others, 2002) and bird movements (Gordon, 2000). Among these studies on birds in desert grasslands in winter, however, only two publications (Bock and others, 1986; Bock and Bock, 1992) specifically dealt with birds in native and exotic grasslands.

In the southeastern United States, research has been conducted on overwintering Henslow's Sparrows (Ammodramus henslowii), a species that breeds in temperate grasslands and that depends on open pineland savannahs in southern states during the winter. Most of the work on Henslow's Sparrows during winter has been concerned with impacts of silvicultural and other land management practices (Plentovich and others, 
1999; Carrie and others, 2002; Tucker and Robinson, 2003; Bechtoldt and Stouffer, 2005). Introduced grasses have not figured prominently in these investigations.

There is, likewise, a legacy of research on grassland birds wintering in Texas. The first of these studies was the classic study of Emlen (1972), and subsequent research during recent decades on wintering grassland birds in Texas has focused on describing habitat use (Grzybowski, 1982, 1983; Igl and Ballard, 1999; Heath and others, 2008) and avian response to land management activities (Baker and Guthery, 1990; Reynolds and Krausman, 1998); however, none of these studies evaluated the effects of native and exotic grasses on grassland bird species. Two recent studies in Texas, however, have investigated native and exotic grasses and their effects on breeding grassland birds (Flanders and others, 2006; Thompson and others, 2009), but only the latter examined grassland birds in winter. Thompson and others (2009) conducted their study in the Southern High Plains of the Texas Panhandle, and no studies on grassland birds in native and exotic grasslands in southern Texas have been conducted.

A number of grassland bird species prefer managed grasslands (burned or grazed), whereas others prefer undisturbed grasslands (Vickery and others, 2000). Some grassland birds, such as Savannah Sparrows (Passerculus sandwichensis), exhibit no preference for burned, mowed, or unmanaged sites (Zuckerberg and Vickery, 2006). In contrast, Sedge Wrens (Cistothorus platensis) prefer undisturbed, densely vegetated grasslands characterized by tall plants (Vickery and others, 2000). The Song Sparrow (Melospiza melodia) tends to be more abundant in unmanaged grasslands (Zuckerberg and Vickery, 2006). In contrast, Killdeer (Charadrius vociferus) quickly colonize recently burned grasslands, but their populations gradually decline following a burn, indicating their preference for sparsely vegetated or unvegetated habitats (Johnson, 1997).

Some grassland-dependent small mammal species also have experienced population declines (Martin and others, 2003). Rodents play an important role as herbivores in grassland ecosystems (Smith, 1980). When compared with other common herbivore groups (arthropods and molluses), rodents have the greatest influence on plant growth and biomass (Hulme, 1996). Many burrowing and fossorial rodents are habitat modifiers, through various mound-building styles, soil disturbances, nutrient inputs, and foraging activities. In addition to grassland modifications, rodents play an important role as primary consumers in grassland ecosystems, and they also serve as the first link in the food chain for many carnivores and raptors (Avenant, 1997). Rodent species that rely on the canopy and litter layers provided by unmanaged grasslands may emigrate from the area if these habitat components are removed. Thus, unknown long-term consequences may follow from ecosystem-wide anthropogenic perturbations such as mowing and controlled burning.

The overall goal of this study was to examine broad ecological patterns related to bird use of native and exotic grasslands of Navy facilities in southern Texas. The following objectives included in this report were undertaken: 1) develop species lists of birds for each of five U.S. Navy facilities included in this study; 2) compare bird species richness and mean numbers of all birds between native and exotic grasslands; 3) compile a list of grass species present at each U.S. Navy facility; 4) compare measures of ground cover composition, floral diversity, and vegetation structure and density of native and exotic grasslands; 5) simplify and compare components of variation in native and exotic grasslands; 6) relate bird species richness and numbers in winter to characteristics of native and exotic grasslands; 7) provide baseline information on total numbers and relative abundance of orders and families of insects and arachnids in native and exotic grasslands; 8) compare family richness of insects and arachnids between native and exotic grasslands; 9) compare seed biomass and diversity between native and exotic grasslands during winter; and 10) compare numbers and diversities of birds and rodents in undisturbed, mowed, and burned exotic grasses.

\section{Study Area}

\section{Gulf Coast and Inland Prairies of Texas}

The study area was located in two Texas ecoregions. Coastal study sites were located in the Gulf Coast Prairies and Marshes ecoregion, and inland study sites were located in the South Texas Plains ecoregion (Texas Parks and Wildlife Department, 2005; modified from Gould and others, 1960).

Coastal prairies along the rim of the Gulf of Mexico, once formerly widespread, occurred from southwestern Louisiana, through most of Texas, and into extreme northeastern Tamaulipas in northern Mexico (Johnston, 1963; Smeins and others, 1991). These once extensive grasslands, though disjunct from the Great Plains, were the southernmost extremity of interior grasslands that once covered the midsection of North America. Southern Texas was considered by Daubenmire (1978) to be in the southern part of the Andropogon (now Schizachyrium) scoparius Province of the Great Plains. This semiarid region is distinct from the rest of the province, in that it also supports subtropical representatives of grasses (Cenchrus, Chloris, Eragrostis, and Paspalum spp.) and woody vegetation, including honey mesquite (Prosopis glandulosa), live oak (Quercus virginiana), and Texas pricklypear (Opuntia engelmannii).

Grasslands formerly occupied much more of southern Texas than they do at present (2010) (Leopold, 1950; Johnston, 1963; Smeins and others, 1991). Grasslands in southern Texas began to undergo rapid conversion to brushland in the late 1800 s, apparently because sustained heavy grazing by domestic livestock had removed the fuel base that previously had supported prairie fires (Lehmann, 1969; Schmidly, 2002; Woodin and others, 2008). Absence of periodic fires permitted woody plants to sprout and proliferate, converting much of southern Texas to its current brush-dominated landscape. In addition to brush encroachment, tracts of native coastal 
prairie that remain in Texas have been altered by agricultural production, fragmentation, and widespread planting of exotic grasses (Johnston, 1963; Rappole and others, 1986; Smeins and others, 1991). Many grasslands that have persisted have been degraded further from seeding with exotic grasses such as buffelgrass (Pennisetum ciliare), johnsongrass (Sorghum halepense), Kleberg bluestem (Dichanthium annulatum), and kleingrass (Panicum coloratum), with the objective of improving livestock forage. By the late $20^{\text {th }}$ century, less than 1 percent of native coastal prairie remained in pristine condition (Smeins and others, 1991).

\section{U.S. Navy Facilities in Southern Texas}

Clustered across the brushlands and remaining prairies of southern Texas are several military facilities of the U.S. Navy (fig. 1). These facilities are described in detail in the Integrated Natural Resource Management Plans, which include brief overviews of habitats and some species lists for each facility (U.S. Department of the Navy, 2002a, 2002b). Most grasslands, native and exotic, on U.S. Navy facilities in southern Texas are mixed-grass prairies. U.S. Navy facilities in southern Texas are located near the shared boundary of Bird Conservation Region (BCR) No. 36 (Tamaulipan Brushlands) and BCR No. 37 (Gulf Coast Prairies) (U.S. Fish and Wildlife Service, 2008).

Two U.S. Navy facilities (Naval Air Station-Corpus Christi and Naval Auxiliary Landing Field Waldron) are located within the Gulf Coast Prairies and Marshes ecoregion, and three facilities (Naval Air Station-Kingsville, Naval Auxiliary Landing Field Orange Grove, and Escondido Ranch) are located in the South Texas Plains ecoregion (Texas Parks and Wildlife Department, 2005; modified from Gould and others, 1960).

Two U.S. Navy facilities are located in Corpus Christi. Naval Air Station-Corpus Christi (NASCC) is a 1,151-hectare (ha) facility in an urban coastal environment. It is bordered by Corpus Christi Bay and the Laguna Madre. The grasslands of NASCC are native coastal prairie, characterized by mid- to tall-grass species [range 100-150 centimeter $(\mathrm{cm})$ in height], and are dominated by seacoast bluestem (Schizachyrium littorale) and gulfdune paspalum (Paspalum monostachyum). Naval Auxiliary Landing Field Waldron (hereinafter referred to as Waldron), also located in Corpus Christi, includes 344 ha

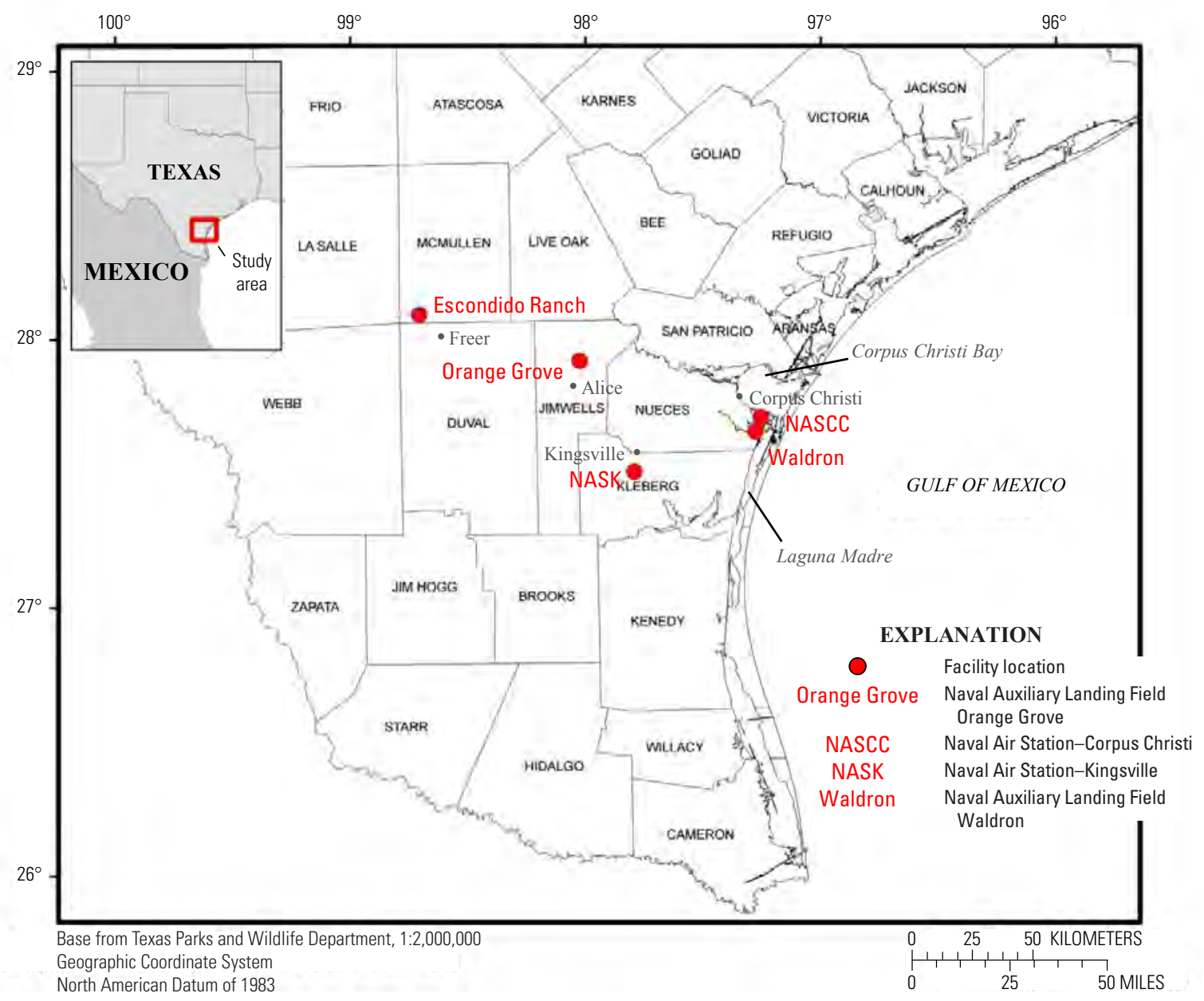

Figure 1. Locations of five U.S. Navy facilities in southern Texas included in the study. 
that support native coastal prairie and live oak-redbay (Persea borbonia) habitats, the latter of which also includes laurel oak (Quercus laurifolia). The grasslands at Waldron are similar to those at NASCC; however, some of the Waldron grasslands are dominated by roundseed panicgrass (rosettegrass; Dichanthelium sphaerocarpon). The Waldron and NASCC grasslands represent a now rare example of pristine mid- to tall-grass coastal prairie, classified as the Ingleside Prairie (Johnston, 1963). These grasslands are diverse, have almost no introduced grass species present, and occur on a deep sand substrate of the Mustang-Daggerhill-Barrada soil series (Natural Resources Conservation Service, 2008).

Naval Air Station-Kingsville (NASK) is a 1,307-ha facility located in Kleberg County in the city of Kingsville, Tex. NASK is the southernmost naval facility in southern Texas and contains a variety of habitats, including grasslands, woodlands, wetlands, and farmland. Native habitats remain on 312 ha of the station; however, virtually no native grassland habitat remains at NASK. The grasslands at NASK are dominated by Kleberg bluestem (an introduced species about $100 \mathrm{~cm}$ tall) and exhibit relatively low plant species diversity. The location of NASK falls within the loamy Victoria-Orelia-Edroy soil series (Natural Resources Conservation Service, 2008).

Naval Auxiliary Landing Field Orange Grove (hereinafter referred to as Orange Grove) is a 556-ha facility located in Jim Wells County, west of NASCC, Waldron, and NASK (fig. 1). The grasslands at Orange Grove are too far inland to be considered coastal prairie. Much of the Orange Grove facility (399 ha) is devoted to haying or farm leases, and almost all of the grasslands there have been converted to exotic species for hay production. Kleingrass, an exotic grass about $120 \mathrm{~cm}$ tall, has become especially prominent at Orange Grove, where only about 80 ha of native plant communities remain, most of which is Tamaulipan thorn scrub. Kleberg bluestem is a secondary dominant grass. Orange Grove features a slightly drier climate with loamy to gravelly soils in the Delmita-Pernitas-Randado soil series (Natural Resources Conservation Service, 2008).

Escondido Ranch (fig. 1), also known as the McMullen Range Complex, is a 2,741-ha facility, with most of the area (86 percent) classified as "unimproved" native brush and grassland. There are numerous stock tanks and ox-bow basins occurring throughout the ranch. Escondido Ranch is used for recreation (primarily hunting), but also has a target range and a Remote Over-the-Horizon Radar (ROTHR) facility. Located in McMullen County, Escondido Ranch is the westernmost naval facility in southern Texas. The soils are clayey, and are in the Montell-Catarina-Maverick series (Natural Resources Conservation Service, 2008).

In addition to Tamaulipan thorn scrub, the predominant habitat type, high-quality inland grasslands also occur at Escondido Ranch. The grasslands occupy open fields and senderos, which are elongated, rectangular areas from which dense brush has been removed to enhance hunting opportunities for white-tailed deer (Odocoileus virginianus) and feral hogs (Sus scrofa). The managed grasslands have been maintained by occasional disturbances in the form of disking, burning, and mowing. These disturbances have been effective in the past in retarding advance of the dense brush surrounding the senderos, although the disturbances also may be a factor in encouraging invasion in the senderos by introduced grass species. Escondido Ranch grasslands have a high plant species diversity, including native short- and mid-grasses, with no single dominant grass species; however, plains bristlegrass (Setaria leucopila), hooded windmill grass (Chloris cucullata), and sand dropseed (Sporobolus cryptandrus) are the most commonly occurring species. Exotic grasses at Escondido Ranch are less prevalent than native species and include Kleberg bluestem, Angleton bluestem (Dichanthium aristatum), kleingrass, and buffelgrass.

\section{Birds in Native and Exotic Grasslands in Winter}

Considerable research has been devoted to assessing habitat use, population densities, and reproductive success of grassland birds breeding in fragmented prairies (Winter and Faaborg, 1999) or intensively managed hayfields (Bollinger, 1995), or to evaluating their response to large-scale modifications of landscape (Herkert, 1998; Hughes and others, 1999). Askins and others (2007) presented an extensive overview of the recent (2007) status of conservation, research, and management of breeding birds of grasslands throughout most of North America.

In contrast to the many studies on habitat use of grassland birds on their breeding grounds (Winter and Faaborg, 1999), studies on the winter ecology of grassland birds generally have been far fewer in number (Knopf, 1994; Igl and Ballard, 1999; Vickery and Herkert, 2001). Exceptions to this overall imbalance have occurred, as illustrated by investigations into the winter ecology of grassland birds using Conservation Reserve Program (CRP) fields in midwestern states (Delisle and Savidge, 1997; Best and others, 1998) and in the Southern High Plains of northwestern Texas (Thompson and others, 2009); studies of avian responses to drought, grazing, and burning in Arizona during the winter (Bock and Bock, 1998; Kirkpatrick and others, 2002); and evaluations of habitat-use patterns of birds in southern Texas during the non-breeding season (Baker and Guthery, 1990; Igl and Ballard, 1999). The identification of habitats used by grassland birds during the nonbreeding season has been recognized as one of the most important information needs to enhance the conservation of grassland birds (Herkert and Knopf, 1998).

Exotic grass species have been introduced widely in the United States and Canada (Wilcove and others, 1998; Herkert and others, 2003) to increase livestock forage and to stabilize soils and reduce erosion. A number of studies have evaluated the impacts of exotic plant species on grassland birds, but many of these studies occurred during the breeding season in the northern Great Plains and midwestern states (Wilson and Belcher, 1989; Best and others, 1998; Davis and Duncan, 
1999; Grant and others, 2004; Lloyd and Martin, 2005). These investigations generally have determined that native grasses, at least for most grassland-nesting bird species, are superior to exotic grass species. Though less frequent, research on breeding birds in native and exotic grasslands in southern states has yielded similar results. Abundance (numbers of individuals) of breeding birds was greater in native-dominated grasslands than in exotic-dominated grasslands in Texas (Flanders and others, 2006). In Arizona, all species were more abundant in native grasslands than in exotic grasslands, except for the Botteri's Sparrow; Aimophila botterii (Bock and others, 1986).

Comparative studies of birds wintering in native and exotic grasslands are relatively fewer in number than studies on breeding birds. In Nebraska, winter bird abundance and diversity in CRP fields planted to native grasses was determined to be greater than in fields planted to exotics (King and Savidge, 1995). In Arizona, bird numbers were greater in native grasses than in exotics (Bock and others, 1986). In northern Texas, CRP fields planted to native species had greater bird numbers and species diversity than exotic grass fields (Thompson and others, 2009). No published studies in subtropical southern Texas, however, where U.S. military installations offer opportunities for management, research, and conservation of migratory birds and biological diversity (Stein and others, 2008), have compared winter bird use of native and exotic grasses. This is the first multi-year study to investigate bird use in winter of native and exotic grasslands in the southern United States.

The following objectives were undertaken: 1) develop species lists of birds for each of the five U.S. Navy facilities included in the study; and 2) compare bird species richness and mean numbers of all birds between native and exotic grasslands. and the dominant grass species at each transect location were recorded. Dominant species were defined as those grass species occupying the greatest area within a transect. Grass specimens that could not be identified in the field were collected and submitted to Dr. Robert Lonard (Department of Biology, University of Texas-Pan Am, Edinburg, Tex.) for identification. Some voucher specimens were collected and housed at the U.S. Geological Survey, Texas Gulf Coast Field Research Station, in Corpus Christi, Tex.

Each study site was classified as exotic, native, agricultural, or previously mowed (within the last year). The exotic and native classifications were based on the relative dominance of exotic and native grass species for each site. Most were easily determined visually as either exotic or native grasslands. Some sites, however, were classified quantitatively using the line transect sampling method (Mueller-Dombois and Ellenberg, 1974), whereby a study site with exotic grass cover of at least 33 percent was classified as exotic. The 33 percent criterion was used because it allowed easy discrimination between exotic and native grasslands. Line transect sampling in exotic grasslands generally yielded greater than or equal to $(\geq) 70$ percent exotic grasses, whereas sampling in native grasslands indicated approximately less than or equal to $(\leq) 15$ percent exotic grasses. Percent native grasses was not used as a criterion for discriminating between native and exotic grasslands, because native grass species occasionally were eclipsed by forbs. Most Navy facilities included either entirely native grassland transects or entirely exotic grassland transects; however, Escondido Ranch had three exotic transects and eight native transects in 2007-08 (table 1). The exotic grasslands were located greater than $(>) 3$ kilometer $(\mathrm{km})$ from the native grassland transects (in a different area of the facility).

\section{Methods}

\section{Grassland Transects}

Grasslands were visited August-November, before each of five winters (2003-2008) of bird surveys, at the following U.S. Navy facilities in southern Texas: 1) Escondido Ranch, McMullen County; 2) NASCC, Nueces County; 3) Waldron, Nueces County; 4) Orange Grove, Jim Wells County; and 5) NASK, Kleberg County. At each of these locations, grassland sites were evaluated for their suitability for prospective bird surveys. Criteria used in selecting grasslands that were considered suitable for subsequent field work included: 1) adequate distance from active runways to prevent interference with air operations; 2) sufficient area in grasses to accommodate a 100 meter $(\mathrm{m}) \times 20 \mathrm{~m}$ transect; 3 ) placement in an area in that the habitat would not be altered during the winter season (not to be hayed, farmed, or mowed); and 4) distance from the next nearest grassland transect location of at least $500 \mathrm{~m}$.

Grass species were identified (using Hatch and others, 1999) at each facility and prospective study site,
Table 1. Numbers of native and exotic grassland transects established at each of five U.S. Navy facilities in southern Texas during five winters, 2003-08.

[Each transect typically was surveyed for birds three times each winter. N, native; E, exotic; NASCC, Naval Air Station-Corpus Christi; Waldron, Naval Auxiliary Landing Field Waldron; NASK, Naval Air Station-Kingsville; Orange Grove, Naval Auxiliary Landing Field Orange Grove]

\begin{tabular}{|c|c|c|c|c|c|c|c|c|c|c|}
\hline \multirow{3}{*}{$\begin{array}{c}\text { U.S. } \\
\text { Navy } \\
\text { facility }\end{array}$} & \multicolumn{10}{|c|}{ Number of transects } \\
\hline & \multicolumn{2}{|c|}{$2003-04^{1}$} & \multicolumn{2}{|c|}{$2004-05^{2}$} & \multicolumn{2}{|c|}{$2005-06^{3}$} & \multicolumn{2}{|c|}{ 2006-07 } & \multicolumn{2}{|c|}{ 2007-08 } \\
\hline & $\mathbf{N}$ & $\mathbf{E}$ & $\mathbf{N}$ & $\mathbf{E}$ & $\mathbf{N}$ & $\mathbf{E}$ & $\mathbf{N}$ & E & $\mathbf{N}$ & $\mathbf{E}$ \\
\hline NASCC & 3 & 0 & 3 & 0 & 3 & 0 & 3 & 0 & 3 & 0 \\
\hline Waldron & 4 & 0 & 4 & 0 & 3 & 0 & 3 & 0 & 3 & 0 \\
\hline NASK & 0 & 6 & 0 & 7 & 0 & 5 & 0 & 0 & 0 & 0 \\
\hline Orange Grove & 1 & 2 & 0 & 0 & 0 & 4 & 0 & 5 & 0 & 0 \\
\hline Escondido Ranch & 8 & 1 & 7 & 1 & 8 & 0 & 8 & 0 & 8 & 3 \\
\hline \multicolumn{11}{|c|}{${ }^{1}$ In addition, four transects in fallow agricultural fields were located at NASK. } \\
\hline \multicolumn{11}{|c|}{$\begin{array}{l}{ }^{2} \text { In addition, five transects in mowed grasslands were located at Escondido Ranch } \\
\text { (two) and NASCC (three). }\end{array}$} \\
\hline${ }^{3}$ In addition three & & & & & & & & & & \\
\hline
\end{tabular}


The initial plan was to use the same transects repeatedly throughout the five winters of the study. This proved to be impractical, as management activities on the U.S. Navy facilities occurred unpredictably. Despite efforts to affect the timing of these activities through frequent coordination with Navy personnel, implementing agricultural hay leases, mowing grasslands to promote game management and enhance airfield safety, and conducting controlled burns for brush management frequently disrupted transects where bird surveys had been planned. Only those transects at NASCC, Waldron, and a few at Escondido Ranch remained throughout the full length of the study. Transects at NASK and Orange Grove (and most of those at Escondido Ranch) were relocated repeatedly because of disturbance by unanticipated management activities. Ultimately, because of repeated disruption of transects, bird surveys were abandoned entirely at NASK during the remaining two winters (2006-07 and 2007-08) and at Orange Grove during the last winter (2007-08) of the study.

Agricultural grasslands were fields lying fallow that had been tilled and planted with row crops within the last 5 years. Mowed grasslands were fields that were mowed at least twice each year, before the 3-month bird survey period. Numbers of grassland transects established during the five winters of the study are indicated for each of the naval facilities by type of grassland (table 1).

\section{Winter Bird Surveys}

At each transect site selected, starting and ending points were marked with stakes, which were capped with sharp metal spines to inhibit perching avian predators, such as Loggerhead Shrikes (Lanius ludovicianus) and small raptors. The long axes of transects $(100 \mathrm{~m} \times 20 \mathrm{~m})$ were oriented so that the rising sun would be behind the observers during a morning bird survey.

Birds were surveyed during the winter (December-February), 2003-2008, at transects at U.S. Navy facilities in southern Texas including: 1) NASCC, 2) Waldron, and 3) Escondido. Birds were surveyed during the winter, 2003-06, at NASK, and during 2003-04 and 2005-07 at Orange Grove. Three winter bird surveys (one per month) were conducted at each of the transects, except during the winter of 2006-07, when prolonged inclement weather conditions prevented completion of bird surveys in January at Orange Grove. Data also are absent from December of 2005 for NASK.

Several bird species known to occupy prairie habitats during the winter in southern Texas are highly secretive, so field methods were employed for conducting winter bird surveys that were patterned after those described by Shackelford and others (2001) and Heath and others (2008). With this technique, personnel move forward synchronously on foot while flushing grassland species. This methodology is known to be especially effective for secretive grassland birds (Heath and others, 2008; Twedt and others, 2008). Crews for each survey included two individuals using a 8 -m long bamboo cane pole to beat the vegetation to flush skulking birds. A third individual, centered between the two pole operators, served as the primary observer to identify birds as they flushed in front of the survey crew, all three of whom steadily moved forward (spaced $5 \mathrm{~m}$ apart) along the length of the transect. All three individuals walked abreast in a straight line during surveys (fig. 2). Birds detected within the $100 \mathrm{~m} \times 20 \mathrm{~m}$ grassland transect were identified and counted. Lateral flushing distance of any bird within a transect to the nearest observer was $\leq 5 \mathrm{~m}$. Flushed birds were monitored until they landed to ensure that no bird was counted twice. Birds flying over the transect, without landing within it, were not counted.

\section{Supplemental Information}

In addition to winter surveys of birds at selected grassland transects, all bird species also were tallied separately that were detected by sight or sound at all five U.S. Navy facilities. Escondido Ranch often is used for ecotourism, so the supplemental information was included for that facility. Point count surveys of breeding birds in grasslands, using methodology modified from Hamel and others (1996), were conducted April-June, 2004, at Escondido Ranch. Species lists of mammals, amphibians, and reptiles that were detected opportunistically during visits (2003-2008) to Escondido Ranch also were tallied.

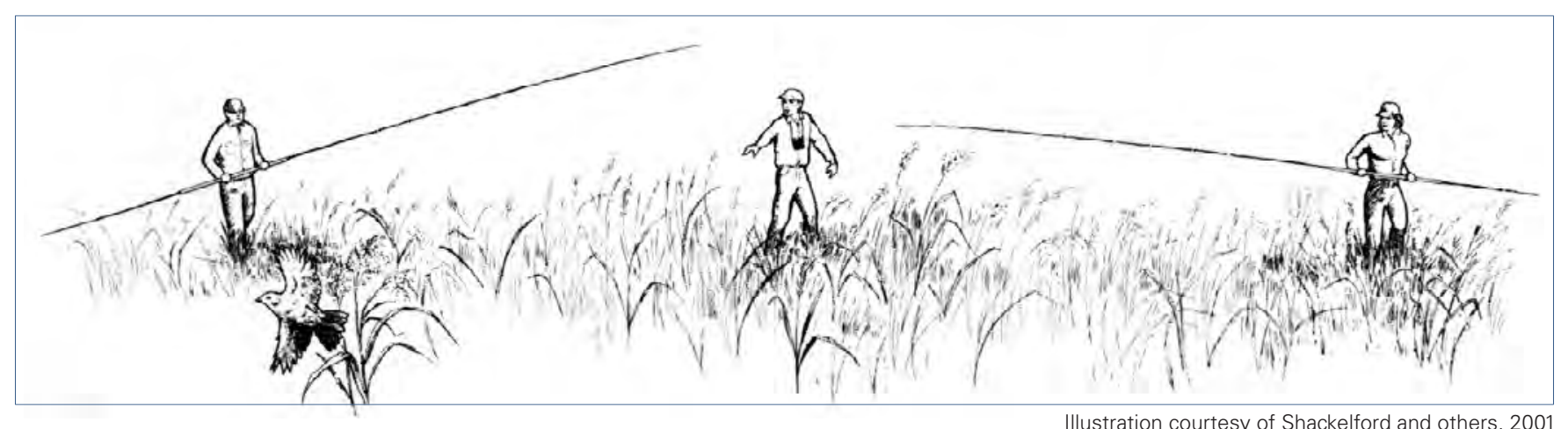

Figure 2. Illustration of technique for surveying wintering grassland birds in southern Texas. Distance between adjacent observers was 5 meters. 


\section{Statistical Analysis}

The distribution of native and exotic grasslands across the five U.S. Navy facilities in the study is shown in table 1. This distribution is characterized by the prevalence of either native or exotic grasslands at individual facilities, nearly to the exclusion of the other type. Transects were placed in native grasslands at NASCC and Waldron, but there were no large tracts of exotic grasses at those facilities in which to place transects (table 1). Transects were placed in exotic grasslands at NASK, but no suitable expanses of native grasses at NASK could be located in which to establish transects. Grasslands at Orange Grove were almost entirely dominated by exotic species, whereas those at Escondido Ranch were dominated heavily by native grass species. As a result, transects at Orange Grove were skewed almost entirely toward placement in exotic grasslands, and placement of transects at Escondido was strongly skewed toward native grasslands (table 1). Furthermore, dominant species of native grasslands were different among facilities, and dominant grass species in exotic grasslands also differed among facilities. As a result of these characteristics of distributions of native and exotic grasses, an assessment of facility effects or comparisons among dominant grass species was not included in the design. Instead, transect data were collapsed across facilities and grass species into two broad categories of grasslands: native and exotic.

Means of monthly surveys for each winter and transect site were calculated. Variables with non-normal distributions were normalized using either natural logarithm or cube root transformations. To evaluate the effects of grassland type and different winters, an analysis of variance (ANOVA) was used to compare overall species richness and mean numbers (abundance) of all birds. Native and exotic classes were used as two levels of grassland type for one of the explanatory variables, and the five separate winters during the study (2003-08) were used for the second explanatory variable. The interaction term was included in the analyses. A similar two-way ANOVA also was used to determine if Savannah Sparrow abundance was related to grassland types (native and exotic) and different winters. In ANOVAs with significant interaction terms, pairwise least squares means tests were used to compare groups. A repeated measures ANOVA was not used because frequent disturbances at NASK and Orange Grove prevented the gathering of repeated measures at most transects in exotic grasslands (see the "Methods" section). All statistical analyses were performed using SAS version 8.2 software (SAS Institute, Cary, N.C.).

\section{Results}

A total of 344 bird surveys at 118 grassland transects were conducted on five U.S. Navy facilities in southern Texas during five winters. A total of 1,044 birds of 30 species were detected (table 2). Only 10 of the 30 (33 percent) species are considered true grassland bird species (table 2); however, of the seven most abundant bird species, six are considered to be true grassland species (table 2), and they accounted for 87 percent of all identified birds.
Table 2. Numbers of birds by species observed during 344 transect surveys in grasslands at five U.S. Navy facilities in southern Texas during five winters, 2003-08.

[True grassland species are denoted by bold type. Species of Conservation Concern (U.S. Fish and Wildlife Service, 2008) are denoted with an asterisk (*)]

\begin{tabular}{|c|c|c|}
\hline Species & $\begin{array}{c}\text { Winter-only } \\
\text { residents }^{1}\end{array}$ & Numbers \\
\hline Savannah Sparrow (Passerculus sandwichensis) & $X$ & 644 \\
\hline Meadowlark (Sturnella spp.) & & 106 \\
\hline Le Conte's Sparrow (Ammodramus leconteii)* & $X$ & 73 \\
\hline Mourning Dove (Zenaida macroura) & & 27 \\
\hline Sedge Wren (Cistothorus platensis)* & $\mathrm{X}$ & 26 \\
\hline Vesper Sparrow (Pooecetes gramineus) & $\mathrm{X}$ & 24 \\
\hline Grasshopper Sparrow (Ammodramus savannarum)* & & 21 \\
\hline Northern Bobwhite (Colinus virginianus) & & 13 \\
\hline Common Ground-dove (Columbina passerine) & & 13 \\
\hline Yellow-rumped Warbler (Dendroica coronata) & $\mathrm{X}$ & 13 \\
\hline Wilson's Snipe (Gallinago delicata) & $\mathrm{X}$ & 11 \\
\hline Long-billed Curlew (Numenius americanus)* & & 8 \\
\hline Black-throated Sparrow (Amphispiza bilineata) & & 8 \\
\hline Lincoln’s Sparrow (Melospiza lincolnii) & $X$ & 8 \\
\hline Killdeer (Charadrius vociferous) & & 4 \\
\hline Northern Harrier (Circus cyaneus) & & 3 \\
\hline European Starling (Sturnus vulgaris) & & 3 \\
\hline Sprague's Pipit (Anthus spragueii)* & $\mathrm{X}$ & 3 \\
\hline Cassin's Sparrow (Aimophila cassinii)* & & 3 \\
\hline Eastern Phoebe (Sayornis phoebe) & $\mathrm{X}$ & 2 \\
\hline House Wren (Troglodytes aedon) & $\mathrm{X}$ & 2 \\
\hline Northern Cardinal (Cardinalis cardinalis) & & 2 \\
\hline Red-tailed Hawk (Buteo jamaicensis) & & 1 \\
\hline Greater Yellowlegs (Tringa melanoleuca) & & 1 \\
\hline Willet (Catoptrophorus semipalmatus) & & 1 \\
\hline Great Horned Owl (Bubo virginianus) & & 1 \\
\hline Loggerhead Shrike (Lanius ludovicianus)* & & 1 \\
\hline Orange-crowned Warbler (Vermivora celata) & $\mathrm{X}$ & 1 \\
\hline Field Sparrow (Spizella fusilla) & & 1 \\
\hline Lark Sparrow (Chondestes grammacus) & & 1 \\
\hline Unknown & & 19 \\
\hline Total & & 1,044 \\
\hline
\end{tabular}


The Savannah Sparrow was the most common bird species observed during the study, accounting for 63 percent of all birds that were identified (table 2). The second most common birds were meadowlarks (Sturnella spp.), which represented 10 percent of all birds that were counted. Eastern Meadowlarks (S. magna) and Western Meadowlarks (S. neglecta) cannot be reliably identified to species by visual cues alone during the winter, but limited calls and singing by meadowlarks revealed that these species were present during the study. The Le Conte's Sparrow (Ammodramus leconteii) was the third most common species observed and accounted for 7 percent of all identified individuals.

Most of the species encountered were uncommon or rare on the transects. Nineteen of the 30 species (63 percent) were detected $\leq 10$ times during the study (table 2 ).

Seven species observed during surveys are considered high-priority species for conservation. Two species, the Longbilled Curlew (Numenius americanus) and Sprague's Pipit (Anthus spragueii), are Species of Conservation Concern for Bird Conservation Region (BCR) No. 36 (Tamaulipan Brushlands), BCR No. 37 (Gulf Coastal Prairie), the Southwestern Region, and for the National List (U.S. Fish and Wildlife Service, 2008). The Loggerhead Shrike is a Species of Conservation Concern for BCR No. 37, the Southwestern Region, and is on the National List (U.S. Fish and Wildlife Service, 2008). The Sedge Wren and Le Conte's Sparrow were encountered, and are Birds of Conservation Concern in BCR No. 37 and the Southwestern Region (U.S. Fish and Wildlife Service, 2008). The Grasshopper Sparrow (Ammodramus savannarum) is a Species of Conservation Concern in BCR No. 37, and the Cassin's Sparrow (Aimophila cassinii) is a Species of Conservation Concern for BCR No. 36.

Bird species richness significantly differed $[F$-statistic for equality of variances $(F)=7.39$; degrees of freedom (d.f.) $=1,95$; probability $(P)=0.01]$ between native and exotic grasslands but not among winters $(F=2.18$; d.f. $=4,95 ; P=0.08)$ or with the interaction of grassland type $\times$ winter $(F=2.34$; d.f. $=4,95 ; P=0.06)$. Mean species richness was 1.6 species per transect plus or minus $( \pm) 0.2$ standard error $(S E)$ in exotic grasses, whereas it was $2.2( \pm 0.2$ $S E)$ in native grasses.

The two-way ANOVA of mean numbers of birds recorded per survey indicated that the interaction term of grassland type $\times$ winter was statistically significant $(F=4.27$; d.f. $=4,96$; $P$ less than $(<) 0.01)$, indicating that mean bird numbers in native and exotic grasses varied differently among winters. During three of the five winters examined, no significant differences in bird numbers existed between native and exotic grasslands; however, during the winter of 2004-05, the mean number of birds in native grasslands was greater (2.5 birds per transect, $\pm 0.5 S E$ ) than mean numbers of birds in exotic grasslands ( 0.9 birds $\pm 0.3 S E$ ). During the winter of 2006-07, the mean number of birds in exotic grasses was greater $(7.7$ birds per transect, $\pm 2.6 \mathrm{SE}$ ) than for birds in either native or exotic grasses in any other winter.
The two-way ANOVA for Savannah Sparrows indicated that their numbers significantly varied $(F=5.35$; d.f. $=4,96$; $P=0.001)$ with the interaction of grassland type and winter. During three of the five winters of the study, no significant differences in numbers of Savannah Sparrows occurred between native and exotic grasslands; however, during the winter, 2003-04, the mean number of Savannah Sparrows was greater in native grasslands (1.5 birds $\pm 0.4 S E)$ than in exotic grasslands $(0.7$ birds $\pm 0.5 \mathrm{SE})$. Savannah Sparrows averaged 7.1 birds per survey in exotic grasslands in 2006-07, more than during any other winter in either native or exotic grasslands.

A list of bird species including all those detected during winter bird surveys, breeding bird point counts, and opportunistic observations during reconnaissance trips to NASCC, Waldron, NASK, Orange Grove, and Escondido is shown in appendix 1, at the back of the report. Mammals that were encountered at Escondido are shown in table 3, of which only the American badger (Taxidea taxus) is recognized as a priority species by the Texas Wildlife Action Plan (Texas Parks and Wildlife Department, 2005). Amphibians and reptiles that were noted are shown in table 4 , five of which are priority species identified in the Texas Wildlife Action Plan (Texas Parks and Wildlife Department, 2005).

Table 3. Mammal species detected during field work at Escondido Ranch, McMullen County, Texas, during 2003-08.

[Texas Priority Species (Texas Parks and Wildlife Department, 2005) are noted with an asterisk (*)]

\begin{tabular}{ll}
\hline \multicolumn{1}{c}{ Common name } & \multicolumn{1}{c}{ Scientific name } \\
\hline Least shrew & Cryptotis parva \\
Mexican free-tailed bat & Tadarida brasiliensis \\
American badger* & Taxidea taxus \\
Coyote & Canis latrans \\
Bobcat & Lynx rufus \\
Ground squirrel & Spermophilus spp. \\
Northern pygmy mouse & Baiomys taylori \\
Fulvous harvest mouse & Reithrodontomys fulvescens \\
Hispid cotton rat & Sigmodon hispidus \\
Gray wood rat & Neotoma micropus \\
Cottontail & Sylvilagus spp. \\
Black-tailed jackrabbit & Lepus californicus \\
Javelina & Tayassu tajacu \\
White-tailed deer & Odocoileus virginianus \\
Feral hog & Sus scrofa \\
Nine-banded armadillo & Dasypus novemcinctus \\
\hline
\end{tabular}


Table 4. Amphibian and reptile species detected during field work at Escondido Ranch, McMullen County, Texas, 2003-08.

[Texas Priority Species (Texas Parks and Wildlife Department, 2005) are noted with an asterisk $(*)]$

\begin{tabular}{ll}
\hline \multicolumn{1}{c}{ Common name } & \multicolumn{1}{c}{ Scientific name } \\
\hline Eastern green toad & Bufo debilis \\
Texas toad & Bufo speciosus \\
Great Plains narrowmouth toad & Gastrophryne olivacea \\
Rio Grande leopard frog & Rana berlandieri \\
Bullfrog & Rana catesbeiana \\
American alligator* & Alligator mississippiensis \\
Red-eared slider & Trachemys scripta \\
Texas tortoise* & Gopherus berlandieri \\
Reticulate collared lizard* & Crotaphytus reticulates \\
Texas banded gecko & Coleomys brevis \\
Texas horned lizard* & Phrynosoma cornutum \\
Texas spiny lizard & Sceloporus olivaceus \\
Texas indigo snake* & Drymarchon corais \\
Southwestern rat snake & Elaphe guttata \\
Ribbon snake & Thamnophis proximus \\
Western diamondback rattlesnake & Crotalus atrox \\
\hline
\end{tabular}

\section{Discussion}

Although a number of studies have been completed during the preceding four decades on grassland birds wintering in Texas, their objectives, field methodologies, and sampling intensities have varied widely. As a result, direct comparisons of bird numbers and species richness among individual studies must be approached with caution, although relative abundances can be valuable in evaluating broad patterns of habitat use by birds. The 30 bird species that were documented in grassland bird surveys during this study was more than the 14 species in grass-forb prairies, or the 21 species in scrub grasslands reported by Emlen (1972) and more than the 14 species documented in grasslands (Grzybowski, 1982) in winter in southern Texas. Emlen (1972), however, excluded raptors and transients in migration, such as swallows and blackbirds, and Grzybowski (1982) excluded raptors and Loggerhead Shrikes from his species totals. Igl and Ballard (1999) detected 25 bird species in grasslands and 46 species in shrub-grasslands in southern Texas in winter. Heath and others (2008) documented 39 bird species that used prairies of the upper Texas coast in winter.

Bird numbers during the present (2010) study were dominated by Savannah Sparrows, a grassland species, which accounted for nearly two-thirds of all birds observed during bird surveys. Savannah Sparrows and five other true grassland species accounted for most birds that were observed, whereas most species, many of which are ubiquitous or can be considered shrubland birds, were represented by only a few tallies. These results are relatively consistent with results of previous studies on grassland birds in southern Texas. Igl and Ballard (1999) reported that 73 percent of all birds in winter in grasslands, and 57 percent of all birds in scrub-grasslands, were grassland specialists, and they also discovered that some grassland species of birds occurred in all non-grassland habitats, including woodlands. Emlen (1972) determined that the most common species in grasslands of southern Texas in winter were Northern Bobwhite (Colinus virginianus), a facultative grassland species, and meadowlarks. The Savannah Sparrow, Vesper Sparrow (Pooecetes gramineus), and Grasshopper Sparrow have been reported as relatively common in grasslands during winter (Emlen, 1972). Other non-grassland species, including the American Robin (Turdus migratorius), Northern Cardinal (Cardinalis cardinalis), and Pyrrhuloxia (Cardinalis sinuatus), also were observed by Emlen (1972) in grasslands of southern Texas. In prairies of the upper Texas coast, Heath and others (2008) also documented a number of non-grassland species in winter, including the Field Sparrow (Spizella pusilla), Loggerhead Shrike, and House Wren (Troglodytes aedon).

Grzybowski (1982) documented that Savannah Sparrows and Le Conte's Sparrows, two grassland-dependent species, dominated southern Texas grasslands in winter, and three other grassland species, the Eastern Meadowlark, the Grasshopper Sparrow, and the Vesper Sparrow, also were relatively common. The Eastern Meadowlark, Savannah Sparrow, Grasshopper Sparrow, Le Conte's Sparrow, and Vesper Sparrow have been reported as the most common species observed wintering in grasslands of southern Texas (Igl and Ballard, 1999). Two common species wintering in grasslands of the upper Texas coast were the Sedge Wren and Le Conte's Sparrow (Heath and others, 2008).

Results of this study indicated that bird species richness in grasslands in southern Texas during winter consistently were greater in native grasslands than in exotic grasses, but total numbers of birds, at least in some winters, can be greater in either native or exotic grasslands. Studies on grassland birds in native and exotic grasslands in winter that can be directly compared to this study's findings are relatively uncommon and offer rather ambiguous results. In a rare study examining winter birds in native and exotic grasslands in southern latitudes, Bock and others (1986) determined that total bird numbers in southeastern Arizona were greater in native grasses than in exotic grasses, but they collected data during only one winter. A few studies have contrasted winter birds in mixes of native and exotic plant species in mid-latitude temperate areas. In southeastern Nebraska, King and Savidge (1995) determined that CRP grassland fields planted with native species had greater bird densities and species richness than CRP fields planted with exotic species. In a subsequent study in southeastern Nebraska, Delisle and Savidge (1997) determined that although bird numbers in winter were larger in CRP fields 
planted to native species than in CRP fields planted to a mix of exotics, birds using CRP fields in winter in Nebraska were limited primarily to Ring-necked Pheasants (Phasianus colchicus) and American Tree Sparrows (Spizella arborea). McCoy and others (2001), on the other hand, reported that bird species richness and total bird use in winter in Missouri did not differ between CRP fields planted to natives and those planted with exotics. In the shortgrass Southern High Plains of northwestern Texas, Thompson and others (2009) determined that CRP fields planted to native grasses had more birds in winter than CRP fields planted to exotic grass species; however, most of the winter birds in CRP fields in this part of the Southern High Plains were meadowlarks, Horned Larks (Eremophila alpestris), and Savannah Sparrows, all relatively common species.

Results of the present (2010) study demonstrate that native grasslands in southern Texas support a greater diversity of bird species in winter than do grasslands dominated by exotic grass species; however, exotic grasslands can support greater numbers of total birds than native prairies during some winters, but this is not consistent among all winters. This indicates that exotic and native grasslands are contributing, albeit in different ways, to the overall diversity and abundance of grassland birds wintering in southern Texas.

\section{Structural and Floristic Characteristics of Native and Exotic Grasslands}

Southern Texas is known for its high diversity of plants (Fulbright and Bryant, 2002). In fact, the Gulf Prairies and Marshes Ecoregion (that includes the coastal part of southern Texas) supports more grass species and grass varieties than any other ecoregion of Texas, is second only to the Edwards Plateau Ecoregion in number of overall plant species, and second only to the Post Oak Savannah Ecoregion in number of plant species/unit area (S.L. Hatch, unpub. data). The Gulf Prairies and Marshes and the South Texas Plains Ecoregions are two of three ecoregions classified as "high priority" ecoregions in the Texas Wildlife Action Plan (Texas Parks and Wildlife Department, 2005). Eight species of federally endangered plants occur in southern Texas, including South Texas ambrosia (Ambrosia cheiranthifolia) and slender rushpea (Hoffmannseggia tenella), which grow in shortgrass native prairies.

Several environmental factors promote greater species richness of plants in southern Texas. Many species of tropical and subtropical Mexico and Central America have their northern limits in southern Texas. A mild subtropical climate encourages nearly year-round growth, and soils range from heavy clays to fine sands. Rainfall varies considerably, with periods of drought abruptly ending with landfall of tropical storms originating in the Gulf of Mexico. Native vegetation is resilient and well-adapted for survival in a fluctuating climate. For example, grasslands in southern Texas quickly recover from drought conditions after rainfall events, exhibiting dramatic transformations from essentially barren fields to lush prairie landscapes (Fulbright and Bryant, 2002).

During times of adequate rainfall, the southern Texas prairies can support a productive livestock industry. In the mid- $20^{\text {th }}$ century, demand grew for better varieties of forage grass. "Improved pastures" were defined as grasslands planted with introduced or hybrid species with good seed production, rapid growth rates, drought tolerance, and which were readily available from a commercial seed source (Nelle, 1992; Ocumpaugh and Stichler, 2000). Introduced grasses such as buffelgrass, bermudagrass (Cynodon dactylon), Kleberg bluestem, King Ranch bluestem (Bothriochloa ischaemum var. songarica), and kleingrass have been used to seed pastures throughout southern Texas (Hatch and others, 1990).

Today, introduced grasses have largely replaced native grasses, resulting in drastic changes to the coastal prairie and inland grassland ecosystems in southern Texas. The widespread occurrence of these introduced grasses, combined with long-term fire suppression and the conversion of many native grasslands to cropland, has been responsible for the loss of $>99$ percent of native grasslands in pristine condition in coastal Texas (Smeins and others, 1991). Research has indicated that exotic grasses reduce plant diversity and support fewer numbers of breeding grassland birds in southern Texas (Flanders and others, 2006, Sands and others, 2009) and in Arizona (Bock and others, 1986); however, no studies have addressed the effects of invasive exotic grasses on wintering grassland birds in southern Texas.

Many species of migratory birds spend the winter in southern Texas grasslands (Emlen, 1972; Grzybowski, 1982; Igl and Ballard, 1999), with most arriving as early as October and remaining in the region until the following spring. Many of these species also occur in other, non-grassland habitats, including shrublands and woodlands (Emlen, 1972; Igl and Ballard, 1999), and non-grassland species often can be detected in grasslands in the winter in southern Texas (this study; Emlen, 1972; Igl and Ballard, 1999). Many migratory grassland birds are federal Species of Conservation Concern and depend on the grasslands of southern Texas for survival (U.S. Fish and Wildlife Service, 2008). To evaluate the importance of native and exotic grass species for wintering grassland birds, it is necessary to compare vegetation characteristics of native and exotic grasslands.

The objectives of this part of the study were 1) to compile a list of grass species present at each of five U. S. Navy facilities in southern Texas; and 2) to compare measures of ground cover composition, floral diversity, and vegetation structure and density of exotic and native grasslands.

\section{Methods}

\section{Data Collection}

Fifty-four $100 \mathrm{~m} \times 20 \mathrm{~m}$ grassland transects were established on five U.S. Navy properties in southern Texas during the 5-year study period. Vegetation data were collected from 
the same transects used for winter bird surveys. In early fall, before each winter bird survey, ground cover composition, floral diversity, and vegetation density were recorded within each $100 \mathrm{~m} \times 20 \mathrm{~m}$ transect site. Ground cover composition and floral diversity were measured within 1-square meter $\left(\mathrm{m}^{2}\right)$ plots marked by a $1.3-\mathrm{cm}$ PVC pipe that was systematically thrown three times (once near each of the two endpoints, and once near the midpoint of transects) along alternating sides of the transect line, about 1-2 $\mathrm{m}$ from the transect line (similar to the methodology in Heath and others, 2008, and Twedt and others, 2008). Throws of the $1-\mathrm{m}^{2}$ frames were made to avoid intentional bias toward one or more of the general vegetation types that were used to compare native and exotic grasslands. Within the sampling plots, percent composition of the following ground cover types was determined: grasses (standing alive or dead; includes sedges, rushes, and reeds), forbs, woody shrubs, litter (flattened, dead vegetation), and bare ground (includes soil and rock) (Daubenmire, 1959; Heath and others, 2008). Percent composition of ground cover was visually estimated at each $1-\mathrm{m}^{2}$ plot by the same two observers (arriving at consensus estimates) throughout the study, in multiples of five. The mean percentages of the three sampling throws were calculated to represent ground cover composition for each transect site per year. To measure floral diversity, all plant species observed within the $1-\mathrm{m}^{2}$ sampling plots were counted. The mean of the three counts was calculated to represent an index of plant diversity for a site. The total number of shrubs within each transect also were counted each year.

Vegetation structure was measured using a variation of the Robel pole (Robel and others, 1970), alternatively called a "cover pole" (Toledo and others, 2008), a "vegetation profile board" (Nudds, 1977; Haukos and others, 1998), or a "density board" (Wight, 1938; Heath and others, 2008). The density board used for this study was 2-m tall and consisted of four 0.5 -m long sections painted black and white, alternately. At the same three sites used for ground cover measurements, one person held the board vertically to the ground, while a second person knelt $15 \mathrm{~m}$ away along the transect. The same kneeling observer at all transects throughout the study estimated the percent of each of the four $0.5-\mathrm{m}$ sections of the board (to the nearest 5 percent) that was visually obstructed, or covered, by vegetation. The means of the three estimates of percent coverage for each of the four sections of the board were used as indices for vertical plant cover estimates at different heights. Variations in this technique (such as distance of the board from observer or the method of assigning values to represent cover data) occur in the literature; however, the use and application of the density board and the resulting measurements are similar (DeVos and Mosby, 1971; Toledo and others 2008). These measurements have been called by various names, including cover density (Wight, 1938; DeVos and Mosby, 1971), foliage density (MacArthur and MacArthur, 1961), vegetation density (Nudds, 1977), visual obstruction (Robel and others, 1970; Benkobi and others, 2000), vertical structure (Haukos and others, 1998; Flanders and others, 2006), and vertical thickness (Shackelford and others, 2001; Heath and others, 2008). In this report, the term "density" is used to refer to the measurement of vegetation structure derived from the density board technique described above. Although it is strongly correlated with biomass (Robel and others, 1970) and standing crop (Benkobi and others, 2000), use of the term "density" in this report does not imply a mathematical calculation for vegetation per unit of area.

Rainfall data were retrieved from the National Climatic Data Center (2003, 2004, 2005, 2006, 2007) using weather stations near each of the five U.S. Navy facilities. Climate data recorded in Corpus Christi weather stations were used for NASCC and Waldron. Climate data recorded in the nearby towns of Freer, Alice, and Kingsville were used for Escondido Ranch, Orange Grove, and NASK, respectively. Monthly rainfall amounts were totaled for the 8-month growing period (March-October) preceding the bird surveys for each winter at each location. If rainfall during the 8-month period was $\geq 30$ percent below normal for a weather station, that period was considered to be "dry". If rainfall during the 8-month period was $\geq 30$ percent above normal, that period was designated as "wet".

\section{Statistical Analysis}

Two-way ANOVA models were used to determine if differences in vegetation characteristics occurred between grassland types (native, exotic), winters (2003-04, 2004-05, 200506, 2006-07, 2007-08), and from the interaction of grassland type and winter. Response variables included five ground cover composition measures (percent grass, forbs, woody, litter, and bare), plant species richness, vegetation density at two heights $(<0.5 \mathrm{~m}, 0.5-1.0 \mathrm{~m})$, and number of shrubs. Variables with non-normal distributions were normalized using square root, natural logarithm, or arcsine/square root transformations. Percent woody cover was not statistically analyzed because of failure to pass normality and equal variance tests. Density data were initially converted to classes (or scores) ranging from 1 to 5 ( 0 to 20 percent $=$ " 1 ", 21 to 40 percent $=$ " 2 ", and so on); however, neither raw nor transformed density score data were normally distributed, so the original percentage data (normalized using square root and arcsine/square root transformations) were used in the models. Vegetation density was analyzed at only the two lower heights (hereafter referred to as density 1 and density 2) because nearly all measures of vegetation density $>1 \mathrm{~m}$ were zero. In ANOVAs with significant interaction terms, pairwise least squares means tests were used to compare groups. Also, the means and standard errors of response variables for all grassland types (agricultural, mowed, native, exotic) were calculated.

\section{Results}

Grass species identified on U.S. Navy lands are listed in appendix 2, at the back of the report. The global origins and chronology of introductions of exotic grass species present on U.S. Navy lands varied extensively (table 5, unpub. data). 
Table 5. List of introduced grass species found on five U.S. Navy facilities in southern Texas, 2003-08, with their places of origin and approximate dates of arrival in the United States.

\begin{tabular}{lllc}
\hline \multicolumn{1}{c}{ Species } & \multicolumn{1}{c}{ Common name } & Place of origin & Arrival \\
\hline $\begin{array}{l}\text { Arundo donax } \\
\begin{array}{l}\text { Bothriochloa ischaemum var. } \\
\text { songarica }\end{array}\end{array}$ & Giant reed & Asia & 1800 's \\
$\begin{array}{l}\text { Bromus catharticus } \\
\text { Chloris gayana }\end{array}$ & Rescuegrass & South America & 1800 's \\
Cynodon dactylon & Rhodes grass & Africa & 1950 's \\
$\begin{array}{l}\text { Dichanthium annulatum } \\
\text { Dichanthium aristatum }\end{array}$ & Bermudagrass & Asia & 1800 's \\
Dichanthium sericeum & Kleberg bluestem & South East Asia & 1930 's \\
Echinochloa colona & Angleton bluestem & Asia & 1920 's \\
Panicum coloratum & Jungle rice & Australia & 1930 's \\
Pennisetum ciliare & Kleingrass & Africa/Asia & pre-1800 \\
Sorghum halepense & Buffelgrass & Africa & 1950 's \\
Urochloa panicoides & Johnsongrass & Africa & 1940 's \\
Urochloa maxima & Liverseed grass & Africa & unknown \\
\hline
\end{tabular}

ground cover variable that differed was percent bare ground $(F=3.79$; d.f. $=4$, 94; $P=0.01)$, which varied throughout the study, but was greatest in 2006-07 and least in 2003-04.

The interaction term of grassland type and winter was statistically significant only for density measurements. Density 1 $(<0.5 \mathrm{~m})(F=3.72$; d.f. $=4,94 ; P=0.01)$ and density $2(0.5-1.0 \mathrm{~m})(F=3.94$; d.f. $=4,94 ; P=0.01)$ varied differently between native and exotic grasslands among winters. This interaction was significant because density 1 and density 2 in exotic grasslands increased in the winters of 2005-06 and 2006-07, whereas vegetation density in native grasslands exhibited declines. Number of shrubs did not differ significantly between native and exotic grasslands.

Rainfall totals at each location from March-October each year (2003-07) are shown in table 7. Dry periods ( $\geq 30$ percent below normal) occurred in 2005 at each site except for NASCC and Waldron (Corpus Christi, Tex.) and in 2006 at Escondido Ranch (Freer, Tex.).

Of the 54 transects established, 21 were classified as exotic grasslands, and 21 were classified as native grasslands. The remaining transects were classified as mowed $(n=5)$ and agricultural $(n=7)$. During the 5-year study period, grassland characteristics within the 54 transects were measured 118 times. No transect was sampled more than once per year, and not all transects were sampled in every year. Compared to the agricultural, mowed, and native grassland types, exotic grasslands exhibited more grass cover and vegetation density, but typically lower forb cover and plant species richness (table 6).

The two-way ANOVA models indicated that exotic grasslands were significantly different from native grasslands in all ground cover composition variables except percent litter and percent woody (not tested) (fig. 3). Exotic grasslands had more grass coverage $(F=43.61$; d.f. $=1,94 ; P<0.0001)$ but less forb cover $(F=54.69$; d.f. $=1,94$; $P<0.0001)$ and less bare ground $(F=22.60$; d.f. $=1,94 ; P<0.0001)$ compared to native grasslands. Native grasslands featured greater plant species richness $(F=102.97$; d.f. $=1,94 ; P<0.0001)$ than exotic grasslands. Among the five winters, the only

Table 6. Vegetation parameters for agricultural fields and mowed, native, and exotic grasslands sampled on five U.S. Navy facilities in southern Texas, 2003-08.

[Ag, agricultural fields; \pm , plus or minus; $S E$, standard error; $<$, less than; m, meter]

\begin{tabular}{lcccc}
\hline \multirow{2}{*}{ Variable } & \multicolumn{4}{c}{ Grassland type } \\
\cline { 2 - 5 } & $\begin{array}{c}\mathbf{A g} \\
(\text { Mean } \pm \boldsymbol{S E} \text { ) }\end{array}$ & $\begin{array}{c}\text { Mowed } \\
(\text { Mean } \pm \boldsymbol{S E} \text { ) }\end{array}$ & $\begin{array}{c}\text { Native } \\
(\text { Mean } \pm \boldsymbol{S E} \text { ) }\end{array}$ & $\begin{array}{c}\text { Exotic } \\
(\text { Mean } \pm \boldsymbol{S E} \text { ) }\end{array}$ \\
\hline Percentage of ground cover: & & & & \\
Grass & $35.7 \pm 7.3$ & $46.3 \pm 9.3$ & $54.9 \pm 2.7$ & $82.9 \pm 2.8$ \\
Forbs & $26.0 \pm 4.1$ & $22.7 \pm 9.3$ & $22.1 \pm 2.1$ & $6.3 \pm 1.9$ \\
Litter & $7.7 \pm 1.0$ & $25.7 \pm 14.1$ & $7.2 \pm 1.2$ & $6.9 \pm 1.7$ \\
Woody & 0 & 0 & $2.5 \pm 0.6$ & $0.8 \pm 0.4$ \\
Bare ground & $30.7 \pm 5.8$ & $5.3 \pm 3.4$ & $13.3 \pm 1.8$ & $3.0 \pm 0.9$ \\
Plant species richness & $6.3 \pm 0.8$ & $6.1 \pm 0.9$ & $7.2 \pm 0.2$ & $3.3 \pm 0.3$ \\
Density 1 $(<0.5 \mathrm{~m})$ & $60.7 \pm 11.8$ & $11.7 \pm 4.8$ & $73.7 \pm 3.3$ & $90.0 \pm 3.2$ \\
Density 2 $(0.5-1 \mathrm{~m})$ & $26.7 \pm 7.8$ & 0 & $28.0 \pm 3.3$ & $47.2 \pm 5.3$ \\
Number of shrubs & $0.4 \pm 0.2$ & 0 & $29.8 \pm 4.7$ & $21.0 \pm 6.5$ \\
\hline
\end{tabular}




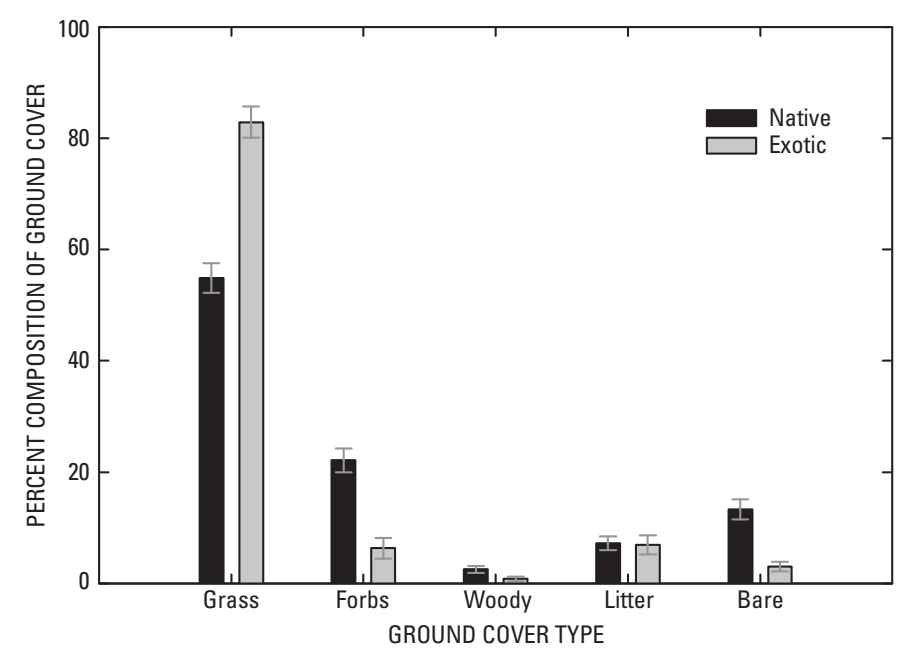

Figure 3. Mean percent ground cover composition ( $\pm 1 S E$ ) of exotic and native grasslands of U.S. Navy lands in southern Texas. Means were calculated from data collected at 21 transects in exotic grasslands and 21 transects in native grasslands for 5 winters (2003-08), but not all transects were sampled in every year.

\section{Discussion}

Results of the present (2010) study demonstrate that grasslands dominated by exotic grass species differ from native grasslands in structure, ground cover composition, and plant species diversity. These findings are supported consistently by other studies of North American grasslands in southern Texas (Long, 2005; Flanders and others, 2006; Sands and others, 2009), desert grasslands of Arizona (Bock and others, 1986), and in the northern (Sutter and Brigham, 1998) and southern Great Plains (Hickman and others, 2006), although some conflicting evidence indicates that CRP fields may be exceptions to these well-established patterns, at least in certain circumstances (King and Savidge, 1995; McCoy and others, 2001). Semi-arid grasslands of interior Australia

Table 7. Rainfall totals during the 8-month growing period (March-0ctober) at weather stations near five U.S. Navy facilities in southern Texas.

[cm, centimeter. Normal rainfall is the mean calculated for 30 years (1961-90) for the same 8-month period. Dry periods (greater than or equal to 30 percent below normal) are indicated in red, and wet periods (greater than or equal to 30 percent above normal) are indicated in blue (National Climatic Data Center, 2003-2007; Ramos and Plocheck, 1997).]

\begin{tabular}{lcccccc}
\hline \multirow{2}{*}{ Weather station } & \multicolumn{7}{c}{ Rainfall (cm) } \\
\cline { 2 - 7 } & Normal & $\mathbf{2 0 0 3}$ & $\mathbf{2 0 0 4}$ & $\mathbf{2 0 0 5}$ & $\mathbf{2 0 0 6}$ & $\mathbf{2 0 0 7}$ \\
\hline Corpus Christi & 59.7 & 63.3 & 84.9 & 56.6 & 79.0 & 95.1 \\
Kingsville & 55.9 & 67.9 & 75.2 & 37.9 & 72.5 & 98.1 \\
Alice & 56.1 & 65.6 & 62.9 & 37.9 & 89.8 & 94.2 \\
Freer & 46.0 & 66.8 & 50.4 & 25.0 & 30.7 & 65.9 \\
\hline
\end{tabular}

indicate similar trends in vegetative characteristics for native and exotic grasslands (Clarke and others, 2005). Cumulatively, the consistent results of these studies clearly establish that exotic grasslands typically create relatively dense grass growth with reduced plant species diversity; in particular, relative importance of forbs is reduced.

Dry conditions occurred at three of the five study sites in the winter of 2005-06 (table 7), which may explain the increase in percent bare ground the following winter (2006$07)$. Density of grassland vegetation was lower in native grassland sites during 2005-06 and the following winter (2006-07); however, vegetation density in exotic grasslands increased during dry conditions. This indicates that exotic grasslands are less affected by dry conditions than are native grasslands. The results of this study indicate that during stressful periodic dry conditions, exotic grasses continued to flourish, whereas native grasses reacted by producing less vegetative growth. During fall, 1984, a drought year, buffelgrass (an exotic species) produced more growth in southern Texas than native grass species (Hanselka and White, 1986). Exotic grasses were the only grasses observed to persist during the severe and prolonged drought of 1950-56 (Stan Reinke, Texas Invasive Plant and Pest Conference, oral commun., 2009). In Australia, Clarke and others (2005) documented that buffelgrass responded differently than native grasses to precipitation patterns, which provided buffelgrass with a competitive advantage over native species with time. Successful plant invasions often are a result of the invading plants' ability to respond to environmental stress with either sustained fitness or increased vigor (Richards and others, 2006; Droste and others, 2009). This could be the mechanism whereby introduced grasses have so successfully excluded many native plant species in southern Texas, where periodic droughts and other dry conditions are a regular occurrence (Fulbright and Bryant, 2002). A possible competitive advantage of exotic grass species during severe droughts indicates that future management and control of these invading species in southern Texas may be exceedingly difficult. Successful control of invasives beyond local infestations may be prohibitively expensive and largely problematic.

This study and others (Bock and others, 1986; Long, 2005; Hickman and others, 2006) indicate that exotic grasslands feature more grass and fewer forbs for ground cover, an overall lower diversity of plants, and a greater vegetational density during dry years, than native grasslands, implying that the introduction of grasses from other continents essentially has created a new ecosystem in southern Texas. Additional research is needed to further address implications of these changes on grassland ecosystems in southern Texas. Also needed are experiments designed to compare and contrast the effects and ecology of multiple species of exotic grasses across the full spectrum of edaphic and moisture gradients that exist in southern Texas. 


\section{Components of Environmental Variation and Bird Use of Grasslands in Winter}

A comparative approach has proven to be an extremely useful technique in testing theories and applied aspects of many disciplines within ecology, including evaluation of the effects of exotic grass species on other biota. Examples of this approach exist for many types of taxa, habitats, and systems (Johnsgard, 1964; McKinney, 1970; Bock and others, 1986; Samways and others, 1996; Flanders and others, 2006). As in the present (2010) study, structural and diversity measures of native and exotic grasslands frequently are measured and compared. Although direct comparisons among responses of habitat types or closely related species are extremely useful, broad ecological patterns nevertheless may remain concealed. The objectives of this component of the study were 1) to simplify and compare components of variation in native and exotic grasslands; and 2) to relate bird species richness and numbers in winter to characteristics of native and exotic grasslands.

\section{Methods}

\section{Statistical Analysis}

Nine measurements of structural, composition, and floral diversity, as described in the preceding section, were available from each of the 104 vegetation surveys conducted during the 5-year study in native or exotic grassland transects (for which there also were bird-use data collected). Vegetation surveys in agricultural fields or mowed grasslands were excluded. Although nine measurements were available, percent woody ground cover was deleted, because the data could not be normalized. The sums of precipitation during the 8 months (March-October) of the growing season preceding the winter bird surveys also were included in the data set for each transect in which birds were counted. To simplify the array of vegetation and weather variables, these nine variables were used in a principal components analysis (PCA) for native and exoticdominated grassland transects. Regression analyses were then performed using total bird numbers and bird species richness as dependent variables and the first three principal component scores from the PCAs as the independent variables.

\section{Results}

The first three principal components (PCs) for native grasslands provided a good summary of the data, accounting for 70 percent of the variation in vegetation and environmental measures of grasslands. The first component (PC1) for native grasslands accounted for 36 percent of the overall variance. PC1 had large positive loadings on the variables grass cover, vegetation density, and rainfall and a large negative loading for bare ground. PC2 captured 22 percent of the variation, and it had large positive loadings for forb cover, number of shrubs, and vegetation density, and a large negative loading for grass cover (table 8). PC3 accounted for about 12 percent of the variance and had a large positive loading for litter cover and a large negative loading for plant species richness (table 8).

Table 8. Eigenvector loadings for variables for the first three principal components (PCs) in the principal components analysis of environmental variation in native grasslands in southern Texas in winter, 2003-08.

[PC1, first principal component; PC2, second principal component; PC3, third principal component; <, less than; m, meter]

\begin{tabular}{lccc}
\hline \multirow{2}{*}{\multicolumn{1}{c}{ Variables }} & \multicolumn{3}{c}{ Principal components } \\
\cline { 2 - 4 } & PC1 & PC2 & PC3 \\
\hline Grass cover & 0.39535 & -0.37112 & -0.25910 \\
Forb cover & 0.12121 & 0.60440 & 0.00483 \\
Litter cover & -0.12570 & -0.13761 & 0.81299 \\
Bare ground & -0.42746 & -0.02562 & -0.08780 \\
Shrub numbers & -0.23247 & 0.45945 & -0.19371 \\
Plant species richness & -0.05891 & 0.11515 & -0.38057 \\
Vegetation density $(<0.5 \mathrm{~m})$ & 0.45743 & 0.29323 & 0.18596 \\
Vegetation density $(0.5-1 \mathrm{~m})$ & 0.42572 & 0.31692 & 0.16948 \\
Rainfall (March-October) & 0.42720 & -0.25806 & -0.13613 \\
\hline
\end{tabular}

The first three PCs for exotic grasslands accounted for 74 percent of the total variation within vegetation and environmental variables. The first component (PC1) for exotic grasslands accounted for 30 percent of the overall variation and had large positive loadings for forb cover, plant species richness, and numbers of shrubs, and a large negative loading for grass cover. The second component (PC2) accounted for 27 percent of the variance and had large positive loadings for vegetation density (density 1 and density 2) and bare ground cover, and a large negative loading for litter cover (table 9). PC3 accounted for 17 percent of the variation, and it had large positive loadings for species richness and rainfall (table 9).

For native grasslands, simple regressions indicated that bird numbers were not related to PC1 $(F=1.79$; d.f. $=1,67$; $P=0.19)$ or PC2 $(F=0.36$; d.f. $=1,67 ; P=0.55)$, but total bird numbers were significantly related to PC3 $(F=10.11$; d.f. $=1,67 ; P<0.01$ ). Simple regressions for native grasslands indicated that bird species richness was not related to $\mathrm{PC} 1(F=0.07$; d.f. $=1,67 ; P=0.80)$ or $\mathrm{PC} 2(F=0.42$; d.f. $=1,67 ; P=0.52)$, but it was significantly related to PC3 $(F=15.26 ;$ d.f. $=1,67 ; P<0.001)$. For exotic grasslands, bird numbers were not significantly related to $\mathrm{PC} 1(P=0.62), \mathrm{PC} 2$ $(P=0.07)$, or PC3 $(P=0.41)$, and bird species richness, likewise, also was unrelated to PC1 $(P=0.16), \mathrm{PC} 2(P=0.35)$, or PC3 $(P=0.84)$. 
Table 9. Eigenvector loadings for variables for the first three principal components (PCs) in the principal components analysis of environmental variation in exotic grasslands in southern Texas in winter, 2003-08.

[PC1, first principal component; PC2, second principal component; PC3, third principal component; $<$, less than; m, meter]

\begin{tabular}{lccc}
\hline \multirow{2}{*}{\multicolumn{1}{c}{ Variables }} & \multicolumn{3}{c}{ Principal components } \\
\cline { 2 - 4 } & PC1 & PC2 & PC3 \\
\hline Grass cover & -0.53771 & 0.23443 & 0.13425 \\
Forb cover & 0.50284 & -0.15443 & 0.17351 \\
Litter cover & 0.24876 & -0.38740 & -0.30352 \\
Bare ground & 0.24624 & 0.30688 & 0.02925 \\
Shrub numbers & 0.34480 & 0.18227 & -0.28968 \\
Plant species richness & 0.35776 & -0.13845 & 0.57599 \\
Vegetation density $(<0.5 \mathrm{~m})$ & 0.12013 & 0.57881 & 0.04484 \\
Vegetation density $(0.5-1 \mathrm{~m})$ & 0.23933 & 0.52285 & 0.11204 \\
Rainfall (March-October) & -0.13005 & -0.12713 & 0.65471 \\
\hline
\end{tabular}

\section{Discussion}

The first three principal components generated from PC analysis of the multivariate data sets for native and exotic grasslands were similar in the proportions of variance that each of the first three components captured, as well as for the cumulative proportion of variance, which in each case was more than two-thirds of the overall variance. Comparison of the individual components revealed, however, that the loadings were different for native and exotic grasslands. For native grasslands, the first PC, capturing the greatest proportion of variation, was relatively evenly weighted, with large positive loadings for grass cover, vegetation densities $1(<0.5 \mathrm{~m})$ and $2(0.5-1 \mathrm{~m})$, and rainfall, and large negative loading for bare ground (table 8 ). These variables seem to represent a composite measure of grass cover and structure or biomass, in association with variable rainfall. $\mathrm{PC} 2$ for native grasslands, likewise, was a composite measure of non-grass ground cover and vegetation density, since it had large positive loadings primarily for shrub and forb growth, but large negative loadings for grass cover. PC3 for native grasslands contributed the smallest amount of explained variation, which was mostly accounted for by variable litter cover. Measures of vegetation density did not contribute to $\mathrm{PC} 3$ in native grasslands.

In exotic grasslands, $\mathrm{PC} 1$ was evenly weighted positively for several components, which suggest a composite measure of non-grass cover, structure, and diversity. PC2 in exotic grasslands includes aspects of overall vegetation density and bare ground. PC3 contains variation related to precipitation and overall plant species richness. Measures of vegetation structure or density did not contribute to PC3 in exotic grasslands.
Measures of structural variation were more important in explaining overall variance in native grasslands than in exotic grasslands. Density measures (for vegetation $<0.5 \mathrm{~m}$ and $0.5-1 \mathrm{~m}$ tall) prominently figured in $\mathrm{PC} 1$ and $\mathrm{PC} 2$ of native grasslands, but they occurred only in PC2 of exotic grasslands.

These results indicate that the variables contributing to explained variation in the first three PCs for native and exotic grasslands differ. This is noteworthy because it demonstrates that not only did individual measures of ground cover, vegetation density, and plant species richness differ between native and exotic grasslands (table 6; Sutter and Brigham, 1998; Hickman and others, 2006; Flanders and others, 2006), but results indicated that the components of variation also differed between native and exotic grasslands. Basic ecosystem functions such as energy and nutrient flows, rates of decomposition, the water cycle, and geochemical processes can be altered by invading exotic species (Christian and Wilson, 1999; Ogle and Reiners, 2003; Lake and Leishman, 2004). Given that these basic functions and processes within ecosystems can be changed by exotic species, perhaps it should not be unexpected that components of variation in ground cover, vegetation structure, and plant diversity, all of which are consequences of interconnected ecosystem functions (energy and nutrient flows and mineral cycling), can differ between native and exotic grasslands.

Although PCA is not an effective statistical tool in identifying cause and effect, it nevertheless is noteworthy that precipitation was included in $\mathrm{PC} 1$ for native grasslands, and strong positive loadings for rainfall, grass cover, and vegetation density indicate that precipitation and growth of grasses are associated in native grasslands. A similar relationship between precipitation and exotic grass species was not detected, indicating that variation in exotic grasses is less associated with rainfall than is variation in native grasses, reinforcing earlier results that indicated that exotics seem to be more resistant to dry conditions; however, precipitation was included in PC3 for exotic grasslands, possibly as a result of an association of rainfall and forb growth.

In native grasslands, results demonstrate that total bird numbers and bird species richness were strongly related to PC3, which primarily was a measure of litter cover in native grasslands. For exotic grasslands, total bird numbers and bird species richness were not related to any of the first three PCs. These contrasting results provide further evidence that native and exotic grasslands function differently.

For decades, theories of species coexistence have been based in large part on the paradigm that interspecific competition, resource partitioning, and vegetation structure in environments plays key roles in the organization of communities and species assemblages (MacArthur, 1958; MacArthur and MacArthur, 1961; Cody, 1968; Cody, 1974). These views have continued to resonate, and many subsequent studies have been characterized by the prevalence of collection of data that measure different aspects of vegetation structure and density. Results of this study, however, indicate that litter cover in native grasslands, which as a part of PC3 actually contributes modestly to overall variation in native grasslands and is not 
a direct measure of structure, is important relative to total bird numbers and species richness. This study indicates that within native grasslands in southern Texas, litter cover has a more prominent affect on numbers and diversity of wintering birds than has been previously recognized. Grassland bird use in exotic grasslands is not related to measures of ground cover, vegetation structure, or plant diversity. The absence of significance for PCs and birds in exotic grasslands is further evidence that grassland birds during winter in southern Texas are not responding strongly to variation in vegetation structure in either native or exotic grasslands. On a much larger scale, Emlen (1972) and Igl and Ballard (1999) discovered that many grassland bird species can be detected during winter in broad physiognomic classes of habitat in southern Texas, where they would not normally be expected to occur, and many non-grassland species wintering in southern Texas often can be detected, somewhat surprisingly, in atypical habitats (this study; Emlen, 1972; Igl and Ballard, 1999). Birds in these circumstances may be responding to other habitat characteristics that were not measured, such as food resources.

\section{Insects and Arachnids in Native and Exotic Grasslands}

The magnitude of the threat of exotic plant invasions may be larger than previously perceived. Native plant displacement by exotics is a primary concern where native grasses and other species are declining. As noted by Wilcove and others (1998), nearly one-half of the species on federally threatened and endangered species lists are at risk because of competition and predation from exotic species. Grassland fragmentation and degradation is a particular concern, because native grasslands have been reduced more than any other biome in North America (Browder and others, 2002).

Studies that compared native and exotic grasslands have determined that native perennial grasses support a greater variety and abundance of indigenous vegetation and animals than do exotics (Bock and others, 1986). Because most species of insects (approximately 75 percent) are phytophagous (Lawton and Strong, 1981), insect diversity is usually positively related to plant biomass, plant structural diversity, and plant species diversity (Rambo and Faeth, 1999).

Diversity of arthropod communities, particularly insects, has been correlated to plant species diversity and structure (Collinge and Forman, 1998; Cameron and Bryant, 1999; Mortimer and others, 2002). Because mowing, grazing, and other management practices alter plant growth, plant structure, and vegetation diversity, these habitat management practices also affect insect communities through space and time. Many insects can be extremely valuable as indicators of land use because of their short life cycles, low dispersal abilities, inabilities to become dormant, and the narrow ecological niches inhabited. Similarly, because of their abundance, rapid reproduction (Fischer and others, 1997), and trophic relationships, insects also are useful for evaluating environmental changes (Canters and Tamis, 1999).

Little is known about species composition and structure of arthropod communities in the prairies of coastal Texas, although Long (2005) and Flanders and others (2006) provided comparative data for native and exotic grasses in grasslands further inland. The objectives of this study component were 1) provide baseline information on total numbers and relative abundance of orders and families of insects and arachnids in native and exotic grasslands; and 2) compare family richness of insects and arachnids between native and exotic grasslands.

\section{Methods}

\section{Data Collection}

Eleven transects were placed in three U.S. Navy facilities in southern Texas. Three were placed in native coastal prairies at NASCC, three were located in native coastal prairies at Waldron, and five were located in exotic grasslands at NASK (fig. 1). Sampling was conducted during all four seasons for one year from March 2005 to March 2006. Seasons were defined by the calendar year: spring (March 20 to June 20), summer (June 21 to September 21), fall (September 22 to December 20), and winter (December 21 to March 19). All 11 transects were sampled using three different techniques - standard sweep-net, random sweep-net, and pitfall trap - to collect various target arthropod groups within the different grasslands.

Arthropods were collected at each transect twice per season using standard sweep-net sampling. A 2-week interval separated the two sample collections. Standard sweep-net sampling was performed by sweeping a solid canvas insect net in a figure-eight motion in front of the observer and grazing the top of the vegetation while walking forward. The net had a circular rim with a diameter of $0.30 \mathrm{~m}$, a conical canvas bag volume of 0.02 cubic meter $\left(\mathrm{m}^{3}\right)$, net length of $0.90 \mathrm{~m}$, and a handle $1.0 \mathrm{~m}$ long. The full figure-eight motion, sweeping left to right, then right to left, was considered one sweep. Fifty sweeps were performed by the same person along the $100-\mathrm{m}$ center line of the transect (approximately one sweep per $2.0 \mathrm{~m}$ ). After 50 sweeps, the contents of the canvas insect net were emptied into a 250 -milliliter $(\mathrm{mL})$ plastic container. The containers were labeled according to the season, Navy facility, transect number, and sample method and then placed in a freezer for 3 days before sorting. The contents were then sorted by removing the vegetation from the containers and separating the sample into insects and spiders, which were subsequently counted and identified to orders and families using Borror and White (1970), Milne and others (1980), and the Integrated Taxonomic Information System (2006). Brief morphological descriptions were noted for insects and spiders, and specimens were grouped within their families based on these descriptions. Insects were classified to species or "morphospecies". Morphospecies were insect types that could not be identified positively to species and were classified based on coarse visual characteristics (Oliver and Beattie, 1996). 
After the initial seasonal sampling, a 2-week interval passed before sampling the second time. Because each transect was sampled twice per season with the sweep-net technique, the two samples were pooled, and the numbers of insects and arachnids were summed within individual families and morphospecies. Arthropod samples were dried and stored for future reference.

Random sweep-net sampling was performed once per season using the same canvas insect net, but the sweeps were not performed with a figure-eight motion. Instead, two people within the transect opportunistically sampled for approximately $20 \mathrm{~min}$ utes. At the end of 20 minutes, each person emptied the canvas net into a single 250-mL container, which was labeled with the season, Navy facility, transect number, and sample method. These random sweep-net samples were processed in the same manner as described above. Numbers of insects and arachnids were summed within individual families and morphospecies.

Pitfall traps also were used to collect above-ground arthropods. Four plastic cups with an open-ended diameter of $10 \mathrm{~cm}$ and a height of $15 \mathrm{~cm}$ were set along the center line of each of 11 transects, spaced $20 \mathrm{~m}$ apart from one another, and buried to ground level. Plastic edging was used to create drift fences, approximately $15-20 \mathrm{~cm}$ long, that met at the pitfall in the center. Pitfall traps were set once per season. The traps were cleaned of debris before sampling, after which one week was allowed to pass before the contents were collected. For each transect, the contents of all four pitfall traps were emptied into a 150-mL container and labeled. Procedures used for sorting, identifying, and enumerating contents from pitfall traps were identical to those used for contents from standard and random sweep-net samples. Overall numbers of insects and insect families collected with the three combined sampling techniques were determined for each season for native grassland and exotic grassland transects. For additional details on field methods and sampling, see Pearce (2007).

\section{Statistical Analysis}

Family richness (total number of families) for each of the two groups of arthropods (insects and arachnids) was compared between native and exotic grasslands. Insect and arachnid data were tested for normal distributions using the Shapiro-Wilk statistic (Shapiro and Wilk, 1965), and two-factor ANOVAs were used to determine the effects of grassland type (native, exotic) and season (spring, summer, fall, winter) on family richness of insects and of arachnids. In ANOVAs with significant interaction terms, pairwise least squares means tests were used to compare groups.

\section{Results}

\section{Insects}

Between March 2005, and March 2006, a total of 15,248 insects were collected, 3,027 from native vegetation and 12,221 from exotic vegetation (table 10). Most insects
(70.3 percent) were collected by random sweep sampling, whereas 27.1 percent and 2.6 percent were collected by standard sweep and pitfall sampling, respectively. When results of the three sampling methods (standard sweep-net, random sweep-net, and pitfall traps) were examined separately, larger numbers of arthropods were trapped in exotic grasslands by standard and random sweep-net sampling. Pitfall traps were the only method that captured greater numbers of insects in native grasslands than in exotic grasslands.

Table 10. Total number of insects by order and grassland type collected in southern Texas, March 2005March 2006.

\begin{tabular}{lrrrr}
\hline \multicolumn{1}{c}{ Order } & Native & Exotic & Total & Percent \\
\hline Blattodea & 0 & 2 & 2 & 0.01 \\
Coleoptera & 553 & 474 & 1,027 & 6.74 \\
Dermaptera & 0 & 2 & 2 & .01 \\
Diptera & 371 & 746 & 1,117 & 7.33 \\
Hemiptera & 513 & 5,459 & 5,972 & 39.17 \\
Homoptera & 438 & 4,302 & 4,740 & 31.09 \\
Hymenoptera & 717 & 451 & 1,168 & 7.66 \\
Lepidoptera & 22 & 95 & 117 & .77 \\
Mantodea & 8 & 0 & 8 & .05 \\
Neuroptera & 11 & 59 & 70 & .46 \\
Odonata & 4 & 27 & 31 & .20 \\
Orthoptera & 292 & 498 & 790 & 5.18 \\
Phasmatodea & 40 & 53 & 93 & .61 \\
Thysanoptera & 57 & 53 & 110 & .72 \\
Thysanura & 1 & 0 & 1 & .01 \\
Total & 3,027 & 12,221 & 15,248 & 100 \\
\hline
\end{tabular}

The total number of insects by order within native and exotic grasslands (all sampling methods combined) and overall percentages of insect orders (combined across all grasslands) are shown in table 10. Five dominant orders were represented in the total number of insects: 5,972 Hemiptera (39.2 percent) [assassin, plant, and seed bugs]; 4,740 Homoptera (31.1 percent) [cicadas, hoppers, and aphids]; 1,168 Hymenoptera (7.7 percent) [wasps, bees, and ants]; 1,117 Diptera (7.3 percent) [flies and mosquitoes]; and 1,027 Coleoptera (6.7 percent) [beetles] (table 10).

In native grasslands, the most common order was Hymenoptera (23.7 percent of all insects) (fig. 4) followed by Coleoptera (18.3 percent), Hemiptera (16.9 percent), Homoptera (14.5 percent), and Diptera (12.3 percent). Orthopterans (grasshoppers and crickets) were about 9.6 percent of all 


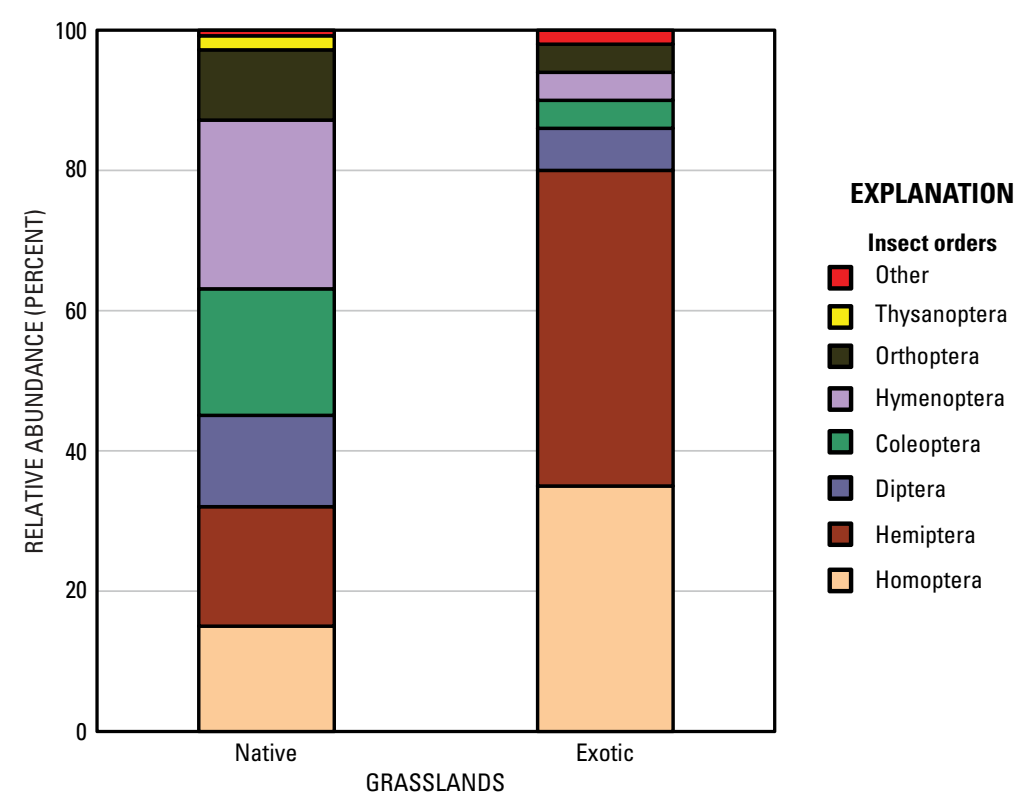

Figure 4. Relative abundances of insect orders within native and exotic grasslands in southern Texas, 2005-06.

insects in native grasslands. Combined, the two most common insect orders in native grasslands (Hymenoptera and Coleoptera) were about 42 percent of all insects.

In exotic grasslands, the most common insect order was Hemiptera (44.7 percent) (fig. 4), followed by Homoptera (35.2 percent). All other insect orders in exotic grasslands accounted individually for $<10$ percent of the total. Combined, the two most common insect orders in exotic grasslands (Hemiptera and Homoptera) were about 80 percent of all insects.

Native and exotic grasslands had a total family richness of 111 and 100 insect families, respectively. Mean family richness was $22 \pm 3 S E$ for native grasslands and $30 \pm 2 S E$ for exotic grasslands. The three most common insect families collected in native grasslands were Formicidae (17.7 percent) [ants], Cicadellidae (12.2 percent) [planthoppers], and Curculionidae ( 7.9 percent) [weevil beetles]. The three most common insect families collected in exotic grasslands were Cicadellidae (33.8 percent), Pentatomidae (27.2 percent) [stink bugs], and Lygaeidae (13.1 percent) [seed bugs]. Insects in native vegetation had a Shannon's diversity index (H') (Shannon, 1948) of 1.4 and evenness of 0.7. Insects in exotic vegetation were less diverse and even (1.0 and 0.5, respectively).

The two-way ANOVA to test for the effects of season and grassland type on insect family richness indicated that the interaction term (season $\times$ grassland type) was significant $(F=6.97$; d.f. $=3,36 ; P<0.001)$, indicating that family richness varied differently among seasons between native and exotic grasslands. The mean and variance of insect family richness by season and grassland type is shown in figure 5 .

\section{Arachnids}

Between March 2005 and March 2006, a total of 2,956 spiders and ticks were collected using random sweep and standard sweep sampling. Of the total number of spiders, 836 were collected from native grasslands and 2,120 from exotic grasslands (table 11). Most (64.9 percent) arachnids were collected by random sweep sampling, whereas 35.1 percent were collected by standard sweep. Only three spiders were collected using pitfall traps, and they were not included in the analyses.

Two orders, Araneae (spiders) and Acari (ticks), were collected, including seven families of araneids and one family of acarids. Although more arachnids were collected from exotic grasslands than from native grasslands, the composition of families was similar within the two types of grasslands (fig. 6). The dominant arachnid families found in native grasslands were Lycosidae (36.0 percent) [wolf spiders], Salticidae (21.9 percent) [jumping spiders], and Thomisidae (8.6 percent) [crab spiders] (fig. 6). The dominant arachnid families found in exotic grasslands were Lycosidae (38.1 percent), Salticidae (18.6 percent), Oxyopidae (11.2 percent) [lynx spiders], and Thomisidae (8.8 percent) (fig. 6). Shannon's diversity index (base 10) was 0.7 for arachnids in native and exotic grasslands, with an evenness of 0.8 and 0.7 , respectively.

The two-way ANOVA to test for the effects of season and grassland type on arachnid family richness indicated that the interaction term (season $\times$ grassland type) was not significant $(F=0.92$; d.f. $=3,36 ; P=0.44)$. The main effect of season

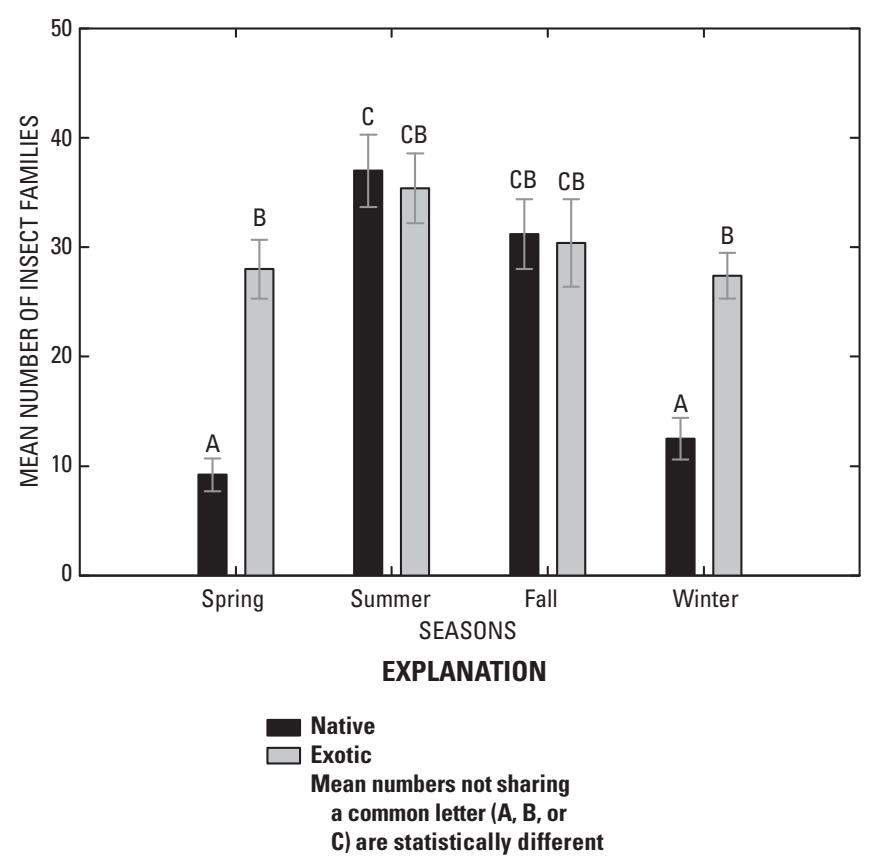

Figure 5. Mean numbers of insect families $( \pm 1 S E$ ) in native and exotic grasslands by season in southern Texas, 2005-06. 
Table 11. Total number of arachnids by order, family, and grassland type collected in southern Texas, March 2005-March 2006.

$[<$, less than $]$

\begin{tabular}{crlrrrr}
\hline Order & Family & \multicolumn{1}{c}{ Common name } & Native & Percent & Exotic & Percent \\
\hline Araneae & Araneidae & Orb weaver & 24 & 3 & 18 & 1 \\
& Filistatidae & Crevice orb weaver & 0 & 0 & 4 & $<1$ \\
& Lycosidae & Wolf spider & 301 & 36 & 808 & 38 \\
& Salticidae & Jumping spider & 183 & 22 & 394 & 19 \\
& Thomisidae & Crab spider & 72 & 9 & 186 & 9 \\
& Oxyopidae & Lynx spider & 36 & 4 & 237 & 11 \\
& Pisauridae & Nursery web spider & 64 & 8 & 126 & 6 \\
& Unknown & Unknown & 151 & 18 & 339 & 16 \\
Acari & Ixodidae & Hard tick & 5 & $<1$ & 8 & $<1$ \\
\hline \multirow{2}{*}{ Total } & & & 836 & & 2,120 & \\
\hline
\end{tabular}

was significant $(F=6.35$; d.f. $=3,36 ; P=0.001)$, indicating that arachnid family richness varied among seasons. Family richness of arachnids was lower in the spring than all other seasons, which did not differ from each other. The other main effect, grassland type, also was significant $(F=12.55$; d.f. $=1,36 ; P=0.001)$, indicating that arachnid family richness differed between native and exotic grasslands. Arachnid family richness in exotic grasses was greater, $6.0 \pm 0.3 \mathrm{SE}$, than it was in native grasslands, $4.8 \pm 0.3 S E$. Additional results can be found in Pearce (2007).

\section{Discussion}

\section{Insects}

During this study, 253 different morphospecies of insects, representing 15 orders and 132 families, were collected from grasslands. Other studies have yielded results comparable to these. For example, Cameron and Bryant (1999) used sweep-net sampling to collect 700 species of insects from 13 orders and 126 families in Texas prairies. Collinge and Forman (1998) used sweepnet sampling to collect 300 species in grasslands.

The top three functional orders collected in this study were Hemiptera [true bugs - herbivore/predator], Homoptera [plant hoppers - herbivore], and Hymenoptera [wasps, bees, and ants - predators]. The diversity of species and morphological features within primary functional groups make insect communities an important part of terrestrial ecosystems (Steffan-Dewenter and Tscharntke, 2002).

An exceptionally large number of hemipterans and homopterans were collected in exotic grasslands. About 33 percent of all insects collected during this study were hemipterans (specifically, Lygaeidae and Pentatomidae families) found in exotic grasslands. Pentatomids (Hemiptera: stink bugs) are economically important; a few pentatomids prey on chewing and sucking insects, but most are phytophagous and can damage cultivated plants. Lygaeids (Hemiptera: seed bugs) are primarily seed feeders and can damage host plants (Lambdin and others, 2003). The other disproportionately large group of insects in exotic grasslands was the homopteran family Cicadellidae. Cicadellids found in exotic grasslands alone accounted for about 27 percent of all insects collected during this study. Cicadellids are known to cause frequent damage to cultivated plants and also can serve as vectors of plant diseases. All three of these abundant families (Lygaeidae, Pentatomidae, and Cicadellidae), primarily found in exotic grasslands of this study, are in the functional group referred to as phytophagous-sucking arthropods (Wiens and Rotenberry, 1979). Their dominance in exotic grasslands indicates that invading grass species may also serve as reservoirs of insect pests and plant diseases.

Coleopterans, one of the most abundant insect orders in native grasslands, are largely predaceous and beneficial in biological control. Important coleopteran families include Cincinelidae (tiger beetles), Coccinelidae (ladybird beetles), and Carabidae (ground beetles). Carabids have the potential to reduce populations of weeds and insects (Carmona, 1998).

Although orthopterans were not among the most abundant insect groups in this study, they were a larger proportion of the total catch within native grasslands than within exotic

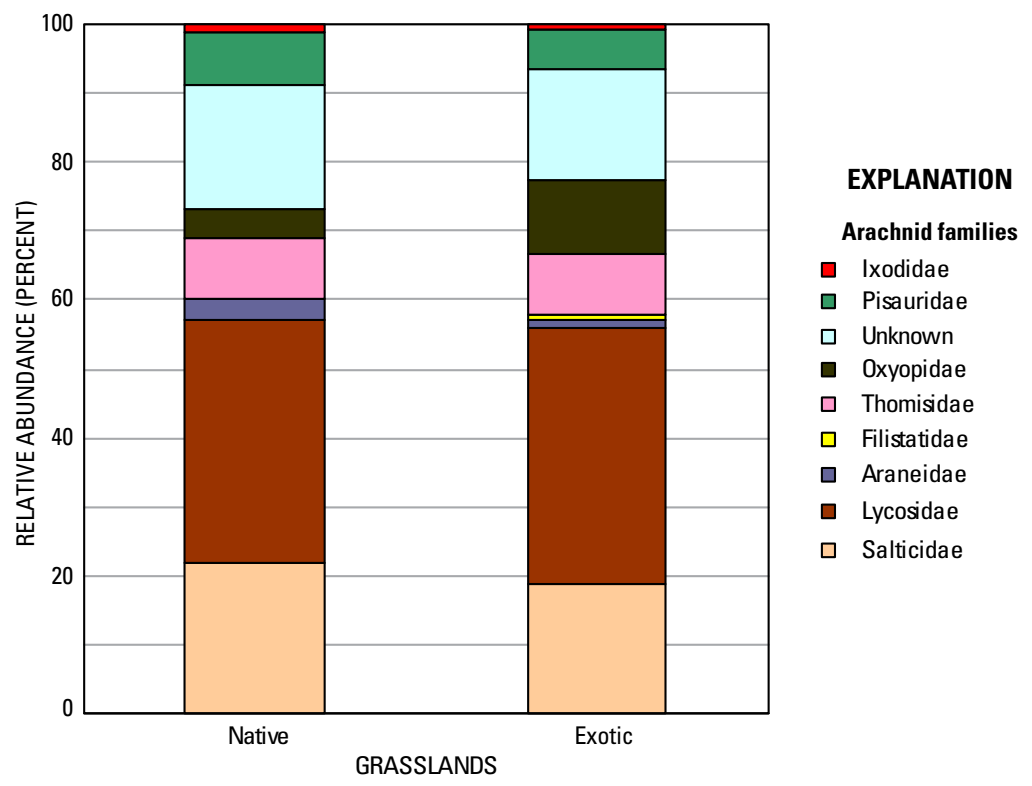

Figure 6. Relative abundances of arachnid families within native and exotic grasslands in southern Texas, 2005-06. 
grasslands. Dennis and Brusven (1993) determined that acrid (grasshopper) assemblages within exotic grasslands were characterized by relatively high densities and low diversities, whereas native grasslands contained simple communities with little diversity. Bock and others (1986) determined that grasshoppers were reduced by 44 percent on exotic grasslands relative to native grasslands. In the present (2010) study, two orthopteran families (Tettigoniidae and Tetrigidae) were more abundant in exotic grasslands, and two other families (Acrididae and Gryllidae) were more abundant in native grasslands.

Grassland type in this study was related to insect family richness. This indicates that the insect assemblages were impacted by the vegetation type, which includes vegetation composition, structure, and diversity; the seasonal variations in family richness reflect the insects' life cycles. In contrast to this study, Bock and others (1986), Flanders (2003), and Long (2005) determined that sites dominated by native perennial grasses supported a greater collective variety or abundance of indigenous plants and animals than did areas planted with exotics. Flanders (2003) concluded that exotic grasses lessen habitat quality and reduce the number of niches available for arthropods associated with native grasses and forbs in southern Texas, because exotic grass sites had lower native herbaceous species richness and appeared to have less herbaceous species diversity.

Vegetation biomass, structural diversity, and plant species diversity are the primary determinants of insect diversity and abundance (Collinge and Forman, 1998; Cameron and Bryant, 1999; Rambo and Faeth, 1999; Bourn and Thomas, 2002;

Kruess and Tscharntke, 2002). Insect assemblages are affected not only by composition, but also by vertical canopy and horizontal spatial structure of the vegetation (Mortimer and others, 2002); however, structure of the surrounding landscape also can affect insect diversity within a patch (Dauber and others, 2003).

\section{Arachnids}

Arachnid family richness was related to grassland type. This indicates that arachnids, like insects, are affected by the composition, structure, and diversity of vegetation. Dennis and others (2001) determined that vegetation composition, mean vegetation height, and grazing intensity accounted for roughly 50 percent of the variability in the species composition and relative abundance of spiders. Spiders may not rank highly in terms of dietary importance for grassland birds (Wiens and Rotenberry, 1979; Kaspari and Joern, 1993); however, there remains little information concerning assemblages of arachnids in native and exotic dominant grasslands or their importance to an ecosystem.

\section{Arthropods as Avian Prey}

Many grassland birds, although generally considered granivorous during the non-breeding season, take arthropods during the breeding season, especially as prey to feed their young. They probably consume arthropods opportunistically in winter, especially in mild subtropical latitudes such as southern Texas, where insects and arachnids remain active and abundant during a large part of the winter season. For example, Littles and others (2007) determined that arthropods represented substantial proportions (mean count $=98$ percent, mean biomass $=29$ percent) of the Burrowing Owl (Athene cunicularia) winter diet in grasslands of southern Texas.

Diet studies generally agree that grassland birds prefer arthropod prey taxa, such as Orthoptera (grasshoppers), Coleoptera (beetles), and Lepidoptera larvae (moth and butterfly larvae), whereas they avoid or limit consumption of other taxa, such as Homoptera (leaf hoppers), Hymenoptera (ants and bees), Hemiptera (true bugs), and Arachnida (spiders) (Wiens, 1973; Wiens and Rotenberry, 1979; Kaspari and Joern, 1993; Littles and others, 2007). Results for exotic grasslands in the present (2010) study included large numbers of arthropod taxa determined to be less desirable as prey for grassland birds (Homoptera and Hemiptera).

\section{Arthropods in Grassland Ecosystems}

Species richness of invertebrate taxa are increasingly being incorporated into conservation and management decisions (Churchill and Arthur, 1999), and relationships between invertebrate species and species assemblages of higher taxa have been noted (Swengel and Swengel, 1999). Cataloging insect and spider species and identifying trophic webs within native and exotic grasslands could help identify keystone or indicator species for each of the respective grasslands. For example, several studies have indicated that grasshoppers are important as functional components of grasslands (Bock and others, 1986; Fielding and Brusven, 1993; Kaspari and Joern, 1993; Fischer and others, 1997; Flanders, 2003).

This study is among only a few conducted in Texas to analyze arthropod data for grasslands and to document differences in invertebrate assemblages and populations between native and exotic grasslands. Exotic grasslands had greater family richness of insects (for two of the four seasons) and spiders (for all seasons combined). These results do not agree with previous studies (Bock and others, 1986; Flanders, 2003; Long, 2005, Hickman and others, 2006), which indicated that native grasslands were associated with higher arthropod biomass or abundance, whereas exotic grasslands were associated with lower biomass or abundance; however, one Texas study (McIntyre and Thompson, 2003) determined that, among CRP sites, abundance and richness of arthropods did not differ between native grasslands and exotic grasslands.

The results of this study may differ from the findings of earlier investigations because of differences in climate, species of exotic grass, and methodology. Coastal sites of this study, 
although in a semiarid region, generally receive more rainfall than inland study sites of previous investigations of arthropods in southern Texas. Flanders (2003) conducted studies in Dimmit and LaSalle counties, and Long (2005) conducted his study in McMullen County. These counties are further west in southern Texas, where precipitation gradients indicate less annual rainfall relative to coastal study sites in Nueces County (Fulbright and Bryant, 2002). For example, Flanders (2003) reported ground cover composition that was much sparser than that measured in this study. On their inland native grassland sites, bare ground cover was 48 percent and grass cover was 15 percent, whereas on coastal native grasslands (this study; NASCC and Waldron), bare ground cover was 8 percent and grass cover was 70 percent.

These disparate results also may reflect differences in the responses of arthropods to dominant grass species. Kleberg bluestem was the dominant grass species at NASK. Previous studies yielding different results were conducted in exotic grasslands dominated by Boer lovegrass (Eragrostis curvula var. conferta) and Lehmann lovegrass (E. lehmanniana) (Bock and others, 1986); kleingrass (Long, 2005); buffelgrass (Flanders and others, 2006); and Old World bluestem (Bothriochloa ischaemum) (Hickman and others, 2006). Future investigations of exotic grasslands should avoid the assumption that the results from species-specific studies of exotic grasses can be extrapolated to other species or other regions.

A difference in methodology between this study and preceding arthropod surveys also may contribute to the different results. The data in this study were obtained by use of three sample collection methods: standard sweep-net, random sweep-net, and pitfall traps. Results from all three methods were combined in analysis, although most of the arthropods (70 percent of insects and 65 percent of arachnids) were captured using the random sweep-net method. This method employs an opportunistic search (20 minutes in duration) for arthropods and may skew sampling results in favor of more visible and unevenly distributed individuals, although the sampling effort and bias were consistent between native and exotic grasslands. In contrast to this study's use of multiple sampling methodologies, Flanders (2003), Long (2005), and Hickman and others (2006) used only the standard sweep-net method in generating their results.

\section{Seed Availability in Native and Exotic Grasslands}

Because many wintering grassland birds are granivorous (seed-eaters), the availability of seed resources may limit the size of bird populations in winter. In the United States, winter seed availability in grasslands has been examined in the Midwest (Bookhout, 1958), southern Great Plains (Robel and Slade, 1965; Grzybowski, 1982; Klute and others, 1997; Ginter and Desmond, 2005), and in the Southwest (Pulliam and Dunning, 1987; Desmond and others, 2008); however, no studies have compared winter seed availability in native and exotic grasslands. The objective of this study component was to compare seed biomass and diversity in native and exotic grasslands during winter.

\section{Methods}

Seed availability was evaluated in grasslands at two Navy properties. Naval Air Station-Corpus Christi was characterized by native coastal grasslands, and grasslands at NASK were predominantly monotypic stands of Kleberg bluestem, an exotic species. Fourteen seed samples were collected from native grasslands at NASCC, and 14 seed samples were collected from exotic grasslands at NASK.

Seed samples from Navy facilities were collected for two seasons (2004-05 and 2005-06), with most samples collected between February 10 and March 3. A 30-square centimeter $\left(\mathrm{cm}^{2}\right)$ metal frame was arbitrarily thrown along one side of the center line in established bird transects at NASCC and NASK. All plant materials (the standing vegetation, ground litter, and upper surface of soil) within the $30 \mathrm{~cm}^{2}$ plots were removed using garden shears (for standing vegetation) and a battery-powered, hand-held vacuum cleaner (Black \& Decker 14.4V Dust Buster) for the ground material (Ault and Stormer, 1983).

After collection, the samples were taken to the lab and carefully sorted to remove all seeds. Dominant seed types were identified to genus and recorded for each sample. The numbers of seed types were determined for each sample and used as a measure of diversity. The seeds collected from each sample were dried at 60 degrees Celsius $\left({ }^{\circ} \mathrm{C}\right)$ for 48 hours and weighed to 0.0001 gram (g) to determine dry biomass [gram per square meter $\left.\left(\mathrm{g} / \mathrm{m}^{2}\right)\right]$. Seed biomass data were transformed to natural logarithms in order to attain a normal distribution. Taxonomic diversity and biomass of seeds were compared in native and exotic samples using Student's $t$-tests $(t)$ (Student, 1908).

\section{Results}

The dominant seed type in exotic grassland samples was Dichanthium spp. The dominant seed type in native grassland samples was Schizachyrium spp. Individual seeds of each of these dominant genuses are similar in size and biomass; therefore, differences in biomass estimates of samples primarily are because of numbers of seeds present, not sizes of individual seeds. Of the 28 samples, only 1 (a native grassland sample) was dominated by forb seeds.

Exotic grasslands had greater seed biomass available than native grasslands $(t=3.18$, d.f. $=26, P<0.01)$. Mean biomass of seeds in exotic grasslands was $3.8 \mathrm{~g} / \mathrm{m}^{2} \pm 1.2 \mathrm{SE}$, and mean biomass of seeds in native grasslands was $1.3 \mathrm{~g} / \mathrm{m}^{2} \pm 0.4 S E$.

Native grasslands had more taxonomic diversity of seeds than exotic grasslands $(t=-5.47$, d.f. $=26, P<0.0001)$. Mean 
number of seed genera in native grasslands was $5.3 \pm 0.5 \mathrm{SE}$, and mean number in exotic grasslands was $2.2 \pm 0.4 \mathrm{SE}$.

\section{Discussion}

Seeds are an important resource for winter survival of birds and other wildlife. Exotic grasslands had more seed biomass available, but the diversity of seeds was less than that observed in native grasslands. Seed diversity within a grassland is important because many granivorous birds indicate strong preferences for some species of seeds while avoiding ubiquitous species (Bookhout, 1958; DiMiceli and others, 2007; Desmond and others, 2008).

Seed sampling in this study was conducted almost entirely post-winter, a time when seed resources are at their lowest because of deterioration and foraging by insects, birds, and mammals (Ripley and Perkins, 1965; Robel and Slade, 1965; Klute and others, 1997; Desmond and others, 2008). Seed biomass estimates almost certainly would have been greater earlier in the winter.

Most bird species that winter in grasslands of southern Texas are granivorous (this study; Emlen, 1972; Grzybowski, 1982; Igl and Ballard, 1999). Numbers of seed-eating birds have been determined to be positively related to winter seed abundance (Grzybowski, 1982; Ginter and Desmond, 2005). Grzybowski (1982) determined that native grasslands and fallow cultivated fields with the greatest abundance of seeds supported the greatest biomass of granivorous birds, whereas sites with lesser seed abundance supported less bird biomass. Although the exotic grassland sites in this study had more than three times the seed biomass of the native grasslands, bird abundance was significantly greater in exotic grasslands only during one winter (2006-07) of the five winters in the study. This may indicate that exotic grass seeds in the study sites (primarily Kleberg bluestem) are not a preferred food resource for wintering grassland birds.

However, some species of exotic grasses are known to provide food for wintering birds. During this study, a Painted Bunting (Passerina ciris) was observed foraging on seeds of guineagrass (Urochloa maxima), an exotic grass species, and Eitniear (2007) also noted a White-collared Seedeater (Sporophila torqueola) feeding on guineagrass seeds in the Rio Grande Valley. In fact, Eitniear (2004) documented that four of nine types of grass seeds consumed by White-collared Seedeaters in the Rio Grande Valley of southern Texas were from exotics, including guineagrass and buffelgrass. Desmond and others (2008) determined that seeds of the introduced stinkgrass (Eragrostis cilianensis) were widely consumed, albeit in small proportions, by multiple sparrow species wintering in southwestern New Mexico. For two of these species (Savannah Sparrow and Vesper Sparrow), however, stinkgrass seeds comprised substantial proportions of the winter foods in certain areas (Desmond and others 2008). Seeds of common crab grass (Digitaria ischaemum), another exotic grass, are sometimes consumed by Northern Bobwhite in southern
Illinois (Bookhout, 1958). Pulliam (1980) determined that the seeds of the introduced Lehmann lovegrass were important in the diet of Chipping Sparrows (Spizella passerina) in Arizona; however, because many granivorous birds prefer seeds of forb species (Bookhout, 1958; Desmond and others, 2008), the reduced forb presence detected in monotypic stands of exotic grasses (this study) may be a factor contributing to reduced bird species richness in exotic grasslands.

\section{Responses of Birds and Rodents to Mowing and Controlled Burns of Exotic Grasslands}

Although natural fires and grazing by native herbivores are beneficial to grassland ecosystems, these natural disturbances have been largely replaced by prescribed fires, livestock grazing, and mowing (Yarnell and others, 2007). As a result, conservation of many grassland bird and rodent populations largely depends on management activities and strategies. Mowing and prescribed burning are two of the most common grassland management practices in southern Texas. Many studies (Igl and Ballard, 1999; Jones and others, 2003; Brennan and Kuvlesky, 2005; Zuckerberg and Vickery, 2006; Yarnell and others, 2007) have evaluated the effects of a wide range of management techniques on grassland organisms; however, few studies have simultaneously assessed the effects of burning and mowing on grassland indicator species such as birds and rodents.

Mowing, unlike grazing, results in non-selective leveling of all vegetation to the same height, and exerts far less force on the ground than grazing animals (via trampling). Mowing also returns seeds and clippings to the ground, which provide an accessible food source for ground-foraging bird and rodent species (Bowden, 1990; Thompson and others, 1991), and returns nutrients to the soil. During the breeding season, frequent or poorly timed mowing may greatly reduce the success of grassland birds by destroying ground nests and essential habitats (Vickery and others, 2001). Excessive mowing may also have detrimental effects on rodent populations. When grassland biomass is reduced below a certain level by mowing, some rodent species may be excluded. For example, $<280 \mathrm{~g} / \mathrm{m}^{2}$ of vegetation cover can effectively exclude voles (Microtus spp.) (Lemen and Clausen, 1984). Mown fields are usually avoided by some small mammals because of reduced shelter, increased predation pressure, and limited food availability (Slade and Crain, 2006); however, mowing may be beneficial to some rodent species because it maintains the early vegetative stages that some prefer (Slade and Crain, 2006).

Prescribed burning often is a suitable grassland management strategy because it allows for multiple management goals to be met at a low cost, and because many native prairie plant species evolved with natural fires. Goals achieved by burning include removal of accumulated thatch and preparation 
of seedbeds for seeding (Duffey and others, 1974; Reed and others, 2004). In addition, burning stimulates growth of new grasses and succulents. In the short-term, burning drastically can reduce cover and result in habitat that is unsuitable for certain small rodents; however, the new growth of rejuvenated young, nutrient-rich plants may increase rodent populations and reproduction in the long-term (Senzota, 1985). The initial effect of burning on rodent and grassland bird populations is extirpation or extermination, because of the fire itself or the resulting decrease in cover and concomitant increased exposure to predation pressures; however, the new growth that occurs after burning can provide new habitat opportunities (Cook, 1959; Lawrence, 1966), as well as increased seed exposure because of the removal of the litter layer (Forde and others, 1984). For example, deer mice (Peromyscus maniculatus) populations responded positively to burning of grasslands (Forde and others, 1984). Prescribed burns conducted under drought conditions can have a negative impact on small mammal diversity in grassland ecosystems (Yarnell and others, 2007); however, little is known regarding the relationship between rates of rodent re-colonization and the subsequent regrowth of burned grasslands.

The goal of this study component was to evaluate the effects of grassland mowing and prescribed burning on grassland birds and rodents in exotic grasslands in southern Texas. The objective was to compare numbers and diversities of birds and rodents in undisturbed, mowed, and burned exotic grasslands.

\section{Methods}

\section{Study Site Selection}

Study areas were selected at NASK to represent burned, mowed, and control sites. All sites were dominated by Kleberg bluestem, although large patches of King Ranch bluestem occurred on control and burned habitat. Five transects were established in each of the three habitat types; each was located at least $20 \mathrm{~m}$ from any adjacent transect. These transects were used to determine abundance of birds and rodents, although transect length varied depending on whether birds or rodents were being sampled.

The area of NASK encompassing the burned treatment plot had been previously burned once between November 2007 and February 2008. This area also was burned again during the study on January 15,2009 . Before this date, the grass height had averaged $94-129 \mathrm{~cm}$. By the end of the monitoring period in June 2009, grass height was 38-69 $\mathrm{cm}$. The mowed treatment plot was mowed on an as-needed basis, and the grass height was maintained at approximately $8-27 \mathrm{~cm}$. Grass clippings remained on the ground after mowing and were allowed to decompose, which resulted in little bare ground in this habitat. The control area remained unmanaged for the duration of the study and was only rarely disturbed by the occasional passage of a vehicle through the area. Average grass height in the control area was $97-122 \mathrm{~cm}$ throughout the study. Areas around the perimeter of the control plot were disturbed during April 2009 by tree, brush, and associated root removal activities, but these activities did not appear to affect rodent captures.

\section{Monitoring Birds and Rodents}

To measure grassland bird abundance and diversity, bird surveys were conducted using the line-transect density estimate (Shackelford and others, 2001; Roberts and Schnell, 2006). Bird survey transects were $100 \mathrm{~m} \times 20 \mathrm{~m}$. Monthly bird surveys were only conducted during winter (defined here as November 15 to February 15). Following the weather and search-area guidelines established by Ralph and others (1993), bird counts were conducted from within 15 minutes of sunrise until about 0900 hours. Methodology for the bird surveys is described in the "Methods" section of the "Birds in Native and Exotic Grasslands in Winter" section of this report (Shackelford and others, 2001; Heath and others, 2008).

To measure rodent diversity and abundance, rodents were live-trapped every fifth week from August 1, 2008 to June 6, 2009. Rodents were trapped for 3 consecutive days using collapsible and non-collapsible aluminum Sherman live-traps $(8 \times 9 \times 23 \mathrm{~cm}$; H.B. Sherman Trap Company, Tallahassee, Fla., USA). Traps remained at the sampling stations in a closed position between trapping events in all plots except in the mowed area, where the traps were removed after each sampling session to avoid damage. Any trap that was damaged, broken, or destroyed during the course of the study was immediately replaced with a functioning trap.

Rodents were trapped along 70-m transects, which were the same transect routes as were used for the 100-m transects for bird surveys. Sixteen traps were laid in two parallel rows along each of five, $70-\mathrm{m}$ transects within the three treatment areas, for a total of 2,400 trap nights per habitat ( 80 traps per habitat $\times 3$ nights $\times 10$ trapping events). After deleting one transect from the study, the control habitat was sampled for 1,920 trap nights. Traps were placed every $10 \mathrm{~m}$, and trap rows were positioned $10 \mathrm{~m}$ apart. Traps were baited with a small handful of generic bird seed, with a short trail of bird seed (approximately 5-8 cm) that led to each trap. Depending on weather conditions, traps were set either in the morning or evening. In warmer weather (May-October), traps were set just before sunset and checked in the morning just after sunrise. Traps were closed during the day to avoid unnecessary mortalities, then opened and reset at sunset for the next trap-night. In the cooler months (November-April), traps were set in the evening before the first sampling morning; the traps were immediately reset after checking and they were allowed to remain open all day. When a rodent was captured, it was removed from the trap and placed into a cloth bag so that it could be identified to species while in the hand. Individuals identified as either white-footed mice (Peromyscus leuco$p u s$ ) or deer mice (P. maniculatus) were grouped for analysis because of the difficulty in differentiating between the two species. All rodents were released unharmed near the trap site. 
Animals recaptured were used to produce population estimates in the different habitat types.

Methods for live-trapping, marking, and releasing rodents were in compliance with guidelines established by the American Society of Mammalogists (1998). For further information on methodology for monitoring birds and rodents in different treatments, refer to Ruddy (2009).

\section{Statistical Analysis}

Rodent captures within transect 5 of the control treatment were significantly different from the other four control treatment transects, thus, data from transect 5 were excluded from the statistical analyses. The difference likely was because of its proximity to dense trees and shrubs. The removal of one control transect resulted in a difference in total trap nights between habitats (mowed and burned $=240$ per event, control $=192$ per event); therefore, rodent captures within each habitat were converted to a standardized capture success rate (Gillespie and others, 2008). For each sampling event, the number of individuals captured within a habitat was divided by the total number of trap nights to obtain the standardized capture values. The standardized capture values were $<1.0$ and were multiplied by 100 before use in the statistical analyses. Diversity of each treatment by sampling event was determined by use of Shannon's diversity index. The greatest possible diversity when using this index is 1.0 .

To determine significant differences in rodent abundances among habitats, the standardized rodent-capture values for each habitat treatment and sampling event $(n=9$ per treatment) were analyzed by use of the non-parametric Kruskal-Wallis analysis of variance (Kruskal and Wallis, 1952). To determine the source of any significant differences, the Kruskal-Wallis analysis was followed by pairwise comparisons with the Mann-Whitney U test and the Bonferroni correction (Mann and Whitney, 1947). Pairwise comparisons were considered significantly different only if the $P$-value was $\leq 0.02$. Also, the Mann-Whitney $U$ test was used to compare pre- and post-burn rodent abundance in the burned habitat. Additional details on statistical evaluation of bird and mammal monitoring is documented in Ruddy (2009).

\section{Results}

Overall, 130 birds representing four species were observed during the four sampling events. The Savannah Sparrow and the Sedge Wren were the two most common species and represented 73.1 and 16.2 percent, respectively, of all observations. These two species were observed during every sampling event (fig. 7). Other species encountered included Eastern and Western Meadowlarks (combined) and Le Conte's Sparrows (fig. 7). Meadowlarks were not observed during February, and Le Conte's Sparrows were not observed during December surveys.

Grassland birds were observed in all habitat treatments except in the burned habitat during January (approximately one week post-burn). On average, grassland birds were most abundant in the mowed treatment (table 12). During the four sampling events, Savannah Sparrows were the most commonly (on average) encountered species (table 12). Sedge Wrens were never encountered in the mowed habitat and were detected in nearly equal numbers in the control and burned habitat treatments. Meadowlarks were similarly abundant in all treatments, whereas Le Conte's Sparrows were detected only in the control habitat. Shannon's diversity index (H') was substantially higher in burned and control habitat treatments than in the mowed treatment.

At the completion of the study, 966 rodents representing six species had been captured during 2,400 trap nights. Hispid cotton rats (Sigmodon hispidus) made up most of the captures (93.0 percent). Hispid pocket mice (Chaetodipus hispidus) were the second most abundant rodent encountered, although

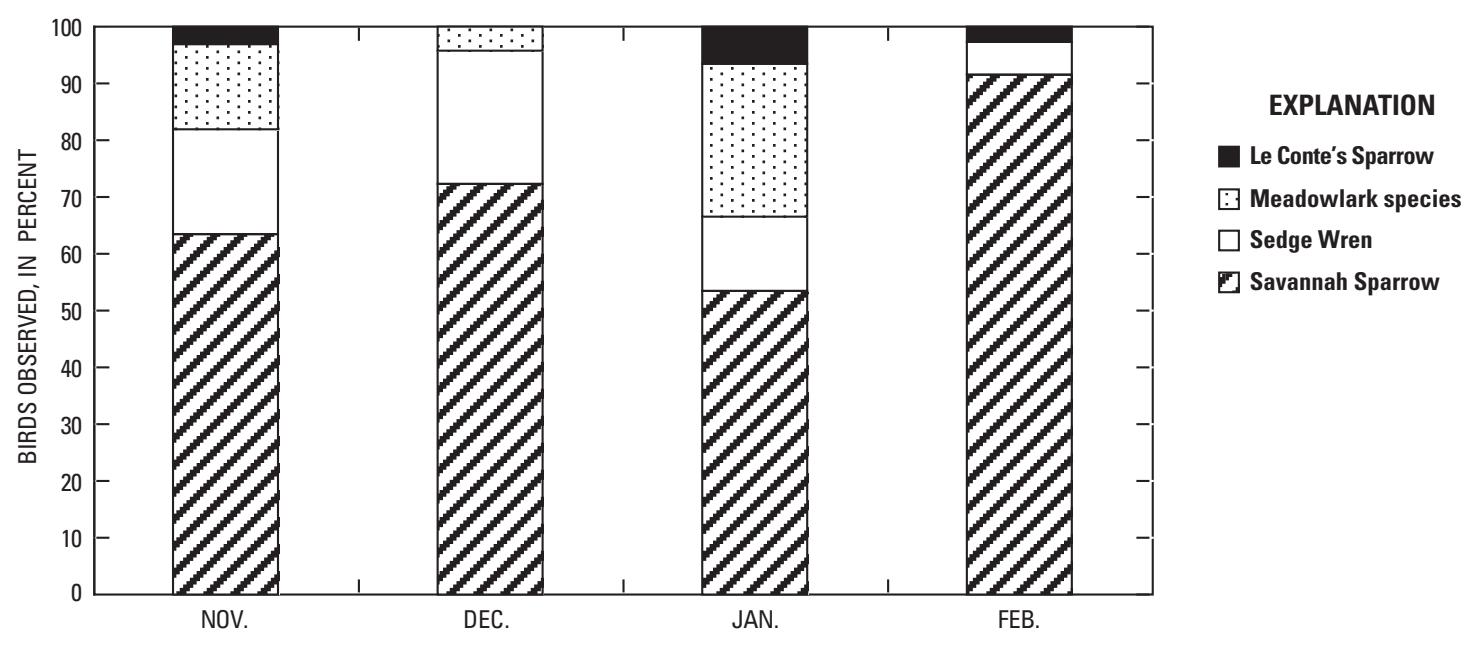

Figure 7. Relative abundance of bird species during each sampling event at Naval Air Station-Kingsville, Kleberg County, Texas, November 2008-February 2009. 
Table 12. Mean abundance (number of birds per transect), standard error (in parentheses), and diversity of grassland birds by treatment.

[H', Shannon's diversity index]

\begin{tabular}{lcccc}
\hline \multicolumn{1}{c}{ Species } & Control & Burned & Mowed & $\begin{array}{c}\text { Overall } \\
\text { mean }\end{array}$ \\
\hline Savannah Sparrow & $7.0(2.3)$ & $4.3(1.7)$ & $12.5(4.4)$ & $23.8(9.7)$ \\
Sedge Wren & $3.0(0.6)$ & $2.3(1.7)$ & $0.0(0.0)$ & $5.3(3.6)$ \\
Meadowlark & $0.5(0.3)$ & $0.8(0.8)$ & $0.8(0.5)$ & $2.0(0.1)$ \\
Le Conte's Sparrow & $0.8(0.5)$ & $0.0(0.0)$ & $0.0(0.0)$ & $0.8(1.0)$ \\
Overall mean & $11.3(2.3)$ & $7.5(2.9)$ & $13.3(4.5)$ & \\
H' & 0.97 & 0.91 & 0.22 & \\
\hline
\end{tabular}

they accounted for only 2.8 percent of all captures. Other species represented were the northern pygmy mouse (Baiomys taylori), white-footed mouse, deer mouse, and house mouse (Mus musculus).

Overall, rodent captures followed a seasonal pattern, peaking December to February and then declining to numbers that were similar to the beginning of the study (fig. 8). Rodent captures were dominated by cotton rats in the control and burned treatments. Captures in the burned and control habitat treatments increased through December, after which captures in the burned habitat drastically declined (figs. 8 and 9B). This dramatic decrease coincided with the prescribed burn event that occurred at the site on January 15, 2009. After the sudden decrease, captures in the burned treatment slowly increased (fig. 8 and 9B). Cotton rats dominated catches in the burned habitat until December; however, beginning in January other rodent species were more frequently captured than cotton rats (fig. $9 B$ ). There was a significant difference in cotton rat abundances pre- and post-burn ( $\mathrm{W}=40, P=0.0097)$. Captures in the mowed habitat treatment were low compared with the other treatments and were mostly dominated by rodents other than cotton rats (fig. 8 and $9 C$ ).

Overall, total rodent captures were more frequent in the control habitat and less frequent in the mowed habitat (table 13). Cotton rats were the most common species encountered. Shannon's diversity index was low because of the complete dominance of cotton rats (98.8 percent of total catch) in the control habitat.

Results of the Kruskal-Wallis ANOVA indicated a significant difference among habitats in the abundance of cotton rats [d.f. $=2$, chi-square $\left(\chi^{2}\right)=43.524$, asymptotic significance $=0.0001]$. Pairwise Mann-Whitney U tests with Bonferroni correction were used to determine the source of the differences between habitats. There were significant differences in numbers of cotton rats between the control and burned treatments [standard score $(Z)=-3.100$, asymptotic significance $=0.002]$, between the control and mowed habitats ( $Z=-6.722$, asymptotic significance $<0.0001)$, and between burned and mowed habitats $(Z=-3.424$, asymptotic significance $=0.001$ ). Additional results are available in Ruddy (2009).

\section{Discussion}

\section{Birds}

The Savannah Sparrow, the most common bird in all three habitat treatments in the study, has a greater affinity for grassy habitats and is prevalent during the winter throughout most of Texas (Rappole and Blacklock, 1994; Sibley, 2000; Zuckerberg and Vickery, 2006). The Sedge Wren was not detected in the mowed habitat or the burned habitat following the prescribed burn. Lack of tall grasses, shrubs for perching, and a litter layer likely contributed to the absence of Sedge Wrens in the mowed and post-burn habitats (Herkert and others, 2001; Dechant and others, 2003). Meadowlarks,

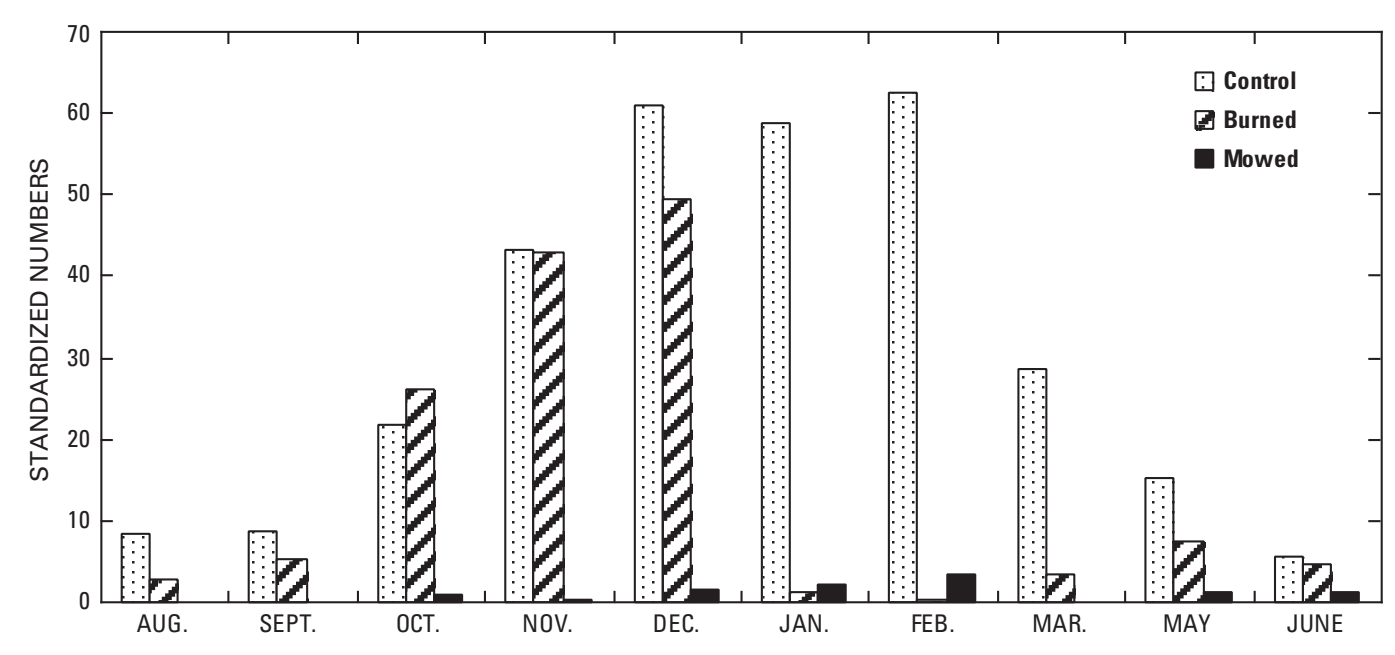

Figure 8. Standardized rodent captures by treatment at Naval Air Station-Kingsville, Kleberg County, Texas, August 2008-June 2009. 

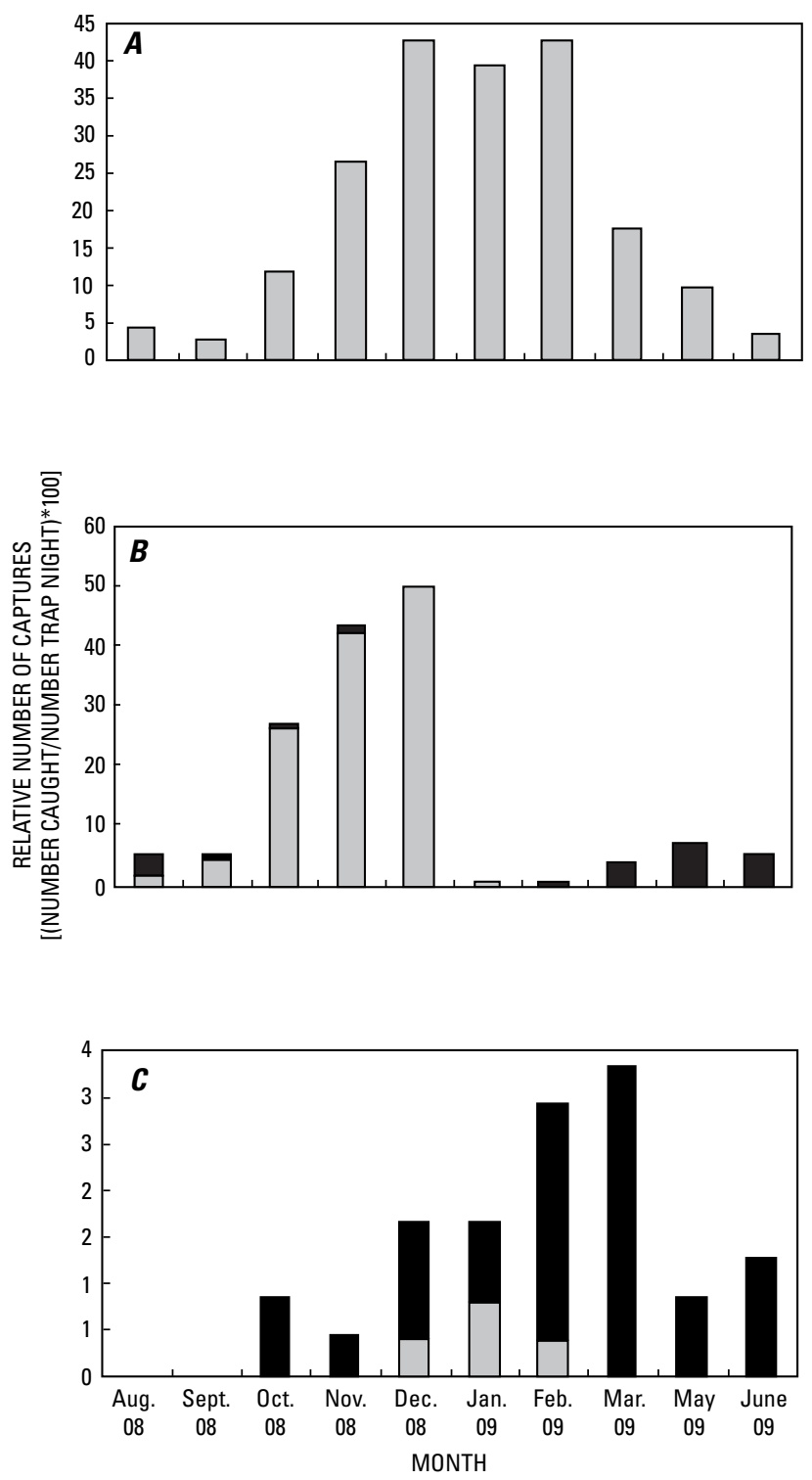

EXPLANATION

Other rodents

$\square$ S. hispidus

Figure 9. Standardized rodent captures in $A$, control habitat, $B$, burned habitat, and $C$, mowed habitat for each sampling event at Naval Air Station-Kingsville, Kleberg County, Texas, August 2008-June 2009.

which were fairly common in the burned and mowed habitat treatments before the prescribed burn, may have relocated to neighboring areas after burning.

Wintering grassland bird diversity may have been greatest in habitats that contained tall and dense vegetation because of increased structural complexity. The control habitat consistently contained tall, dense vegetation (primarily grass) throughout the study. The high overall diversity documented within the burned habitat was probably because of its relatively unmanaged status before the prescribed burn. Following the prescribed burn, diversity and overall grassland bird abundance within this habitat was greatly reduced. Minimal diversity in the mowed habitat treatment may have been a consequence of limited escape cover, perching sites, or foraging opportunities, making these managed habitats undesirable for some species such as the Sedge Wren. Although it was apparent that the short grass heights maintained in the mowed habitat treatment decreased avian diversity, overall abundance of grassland birds was greater when compared to the control habitat (consistently tallest grass) and the burned habitat (variable grass heights). Some bird species are attracted to mowed habitats; for example, Milroy (2007) demonstrated that Eastern Meadowlarks preferred habitats supporting short-grass cover rather than those with tall grass.

\section{Mammals}

The high catch rate of cotton rats was expected in the control and burned habitats because of the presence of tall grasses and extensive vegetation cover (Stokes, 1995; Long and Henke, 2004; Schmidly, 2004). Cotton rats have enormous reproductive potential. Becoming sexually mature within about 40 days after birth, a female typically averages 5 litters of 2 to 10 young per year (Schmidly, 2004). Additionally, cotton rats are active night and day, which may allow them to be more competitive for available resources than other species. The second most abundant species encountered during this study was the hispid pocket mouse; however, hispid pocket mice typically prefer areas of sand or other friable soil that is easy to dig with only scattered vegetation cover (Schmidly, 2004). These habitat characteristics were not present at many of the NASK sites, so the low relative abundance of hispid pocket mice was not unexpected.

In general, rodent populations were correlated with predicted seasonal trends (Cook, 1959; Schmidly, 2004). Rodent captures within all habitat treatments were relatively low August through October 2008. Rodent captures increased November 2008 through March 2009, as temperatures cooled, and then captures began to decrease as temperatures increased

Table 13. Mean abundance of grassland rodents, standard error (in parentheses), and diversity by treatment.

[H', Shannon's diversity index]

\begin{tabular}{lcccc}
\hline \multicolumn{1}{c}{ Species } & Control & Burned & Mowed & $\begin{array}{c}\text { Overall } \\
\text { average }\end{array}$ \\
\hline Sigmodon hispidus & $38.9(9.9)$ & $29.7(14.7)$ & $0.4(0.2)$ & $69.0(20.7)$ \\
Chaetodipus hispidus & $0.2(0.2)$ & $2.2(1.0)$ & $0.0(0.0)$ & $2.4(1.0)$ \\
Baiomys taylori & $0.1(0.1)$ & $0.4(0.3)$ & $1.6(0.5)$ & $2.1(0.4)$ \\
Mus musculus & $0.1(0.1)$ & $1.0(0.5)$ & $0.1(0.1)$ & $1.2(0.3)$ \\
Peromyscus sp. & $0.0(0.0)$ & $0.8(0.3)$ & $0.0(0.0)$ & $0.8(0.3)$ \\
Overall average & $39.3(9.9)$ & $34.1(14.0)$ & $2.1(2.0)$ & \\
H' & 0.07 & 0.54 & 0.67 & \\
\hline
\end{tabular}


at the end of the study. The results of this study are similar to the temporal trend reported by Cameron and Kruchek (2005), with the smallest number of rodents in coastal Texas occurring in spring months, then increasing from summer through winter. Conversely, other studies conducted in different regions of the United States have indicated a reciprocal trend in rodent populations, with peaks in the more temperate summer and abundance lows coinciding with the harsh winter months (Wiegert, 1972).

Before the prescribed burn, rodent captures within the burned habitat were similar to those of the control habitat. Absence of rodents immediately following the burn may have been because of frequent mortality and predation, as indicated by raptors scavenging on rodent carcasses (E. Earwood, U.S. Department of Agriculture, oral commun., 2009). Following the prescribed burn, rodent captures slowly increased as vegetation regrew (February-June 2009). After the burn, cotton rats were probably absent because the shorter vegetation and lack of ground cover reduced the overall habitat quality for many rodents (Cook, 1959), including cotton rats.

Some small mammal species are more likely to be detected in areas that are less densely vegetated (Lemen and Clausen, 1984; Jones and others, 2003; Schmidly, 2004). Peromyscus spp. captures increased 100 percent in the burned habitat treatment following the prescribed burn. Other studies also have noted increases in Peromyscus spp. abundance in cleared areas shortly after prescribed burns within grassland habitats (Cook, 1959; Beck and Vogl, 1972; Forde and others, 1984). Forde and others (1984) reported that seed exposure following the removal of litter likely benefits this genus. Additionally, the post-burn brush removal that also occurred within the burned habitat treatment plot may have allowed for easier excavation of underground burrows. Brush removal and root tilling made the ground more friable, thereby creating a more desirable habitat for the hispid pocket mouse (Schmidly, 2004).

Heteromyids (such as hispid pocket mouse) can comprise the greatest proportion of rodent captures from habitats that contain sparser and shorter vegetation, as well as areas with bare ground (Jones and others, 2003). Furthermore, Killgore and others (2009) indicated that heteromyids were more common within burned than in unburned grasslands, which is consistent with the results from this study. Additionally, murids (such as Sigmodon and Baiomys spp.) were most common in areas with taller, denser vegetation (Jones and others, 2003). Members of the family Muridae were more prevalent than the Heteromyidae in all habitats except those that did not contain sufficient ground cover and grass canopies.

The mowed habitat offered no predictable rodent trend during the study. Unlike the other habitats, no rodents were captured within the mowed habitat until October 2008. As the study progressed, rodents were occasionally captured. Although rodent captures were extremely low within this habitat overall, rodent abundances were generally still affected by temperature and declined as temperatures began to rise.
Rodent population sizes in southern Texas may peak during the relatively temperate winter. Added moisture in the environment and lack of sweltering heat decrease mortality, allowing populations to increase. In contrast, the high average temperatures $\left(33.9-35.0^{\circ} \mathrm{C}\right)$ and low average precipitation $(5.5-8.6 \mathrm{~cm})$ during summer months may have contributed to the low rodent catch rates during these months. Dry periods increase nutritional stress and, in turn, reduce the production of offspring, which commonly cause small mammal populations to significantly diminish (Schmidly, 2004; Fulbright and Hewitt, 2007). Additionally, lack of rainfall in a region may lead to reduced seed production in plants, which results in diminished food sources for granivorous rodents. Many rodents that rely on seed as a food source also rely on seed for metabolizing water and remaining hydrated. Lack of this water source can directly affect the vitality of rodent populations in drought areas.

Each habitat was subjected to a unique management strategy for the duration of the study. Managed habitat treatments exhibited greater levels of rodent diversity than the unmanaged (control) habitat. Furthermore, the mowed habitat exhibited the overall greatest species diversity. The greater diversity in the managed habitats in this study reflects the absence of cotton rats for at least 50 percent of the sampling events. Brady and Slade (2001) similarly demonstrated that overall rodent diversity increased in the absence of cotton rats. Yarnell and others (2007) reported that rodent diversity tends to be greater in habitats that are burned or mowed, which coincide with the results obtained in this study.

\section{Management Considerations}

Burning temporarily reduces habitat suitability for most wintering grassland birds, although within a month grassland birds revisited the burned habitat. With time, the number of birds using the burned area tended to increase. If a burn occurred early in the winter (late November) or in late summer (before migrations begin), it is likely that a smaller number of arriving wintering grassland birds would have been attracted to the site because of reduced vegetation (cover and food source); however, if conservation of wintering grassland bird habitat is the primary goal, selective mowing, while maintaining some unmanaged sites, would likely be effective in attracting grassland birds.

The cotton rat prefers tall grasses, which provide a protective canopy, nesting material, and forage; therefore, removal of tall grasses would reduce habitat suitability and could effectively reduce abundance of the species. The mowed habitat treatment was not favored by the cotton rat during this study, and indeed, few rodents were detected in the habitat. Burning proved to be an effective short-term management strategy for controlling cotton rats; however, small mammal populations increased as the vegetation emerged after the burn. Another consequence of control of cotton rats in the study is that overall rodent diversity increased. When cotton rat popu- 
lations occurred at greater densities, Brady and Slade (2001) determined that overall rodent community diversity declined.

\section{Synthesis and Conclusions}

The results from this study indicate that prairies dominated by native grasses and those dominated by exotic grasses are two different types of grassland (table 14). Of the total of 28 characteristics that were measured and analyzed in grasslands, 21 (75 percent) differed (albeit some only temporally) between native and exotic grasslands, and 7 measures indicated no difference. Five of seven characteristics of bird use or bird response that were measured indicated differences between native and exotic grasslands (table 14). Of the 14 characteristics of ground cover, vegetation density, and floristic diversity, 11 (79 percent) differed between native and exotic grasslands (table 14), and 5 of 7 (71 percent) measures of arthropod diversity differed between native and exotic grasslands.

Results indicate that birds, native plants, insects, and arachnids respond differently in native and exotic grasslands. These widespread differences likely extend as well to other biota or specific taxa in grassland ecosystems, which often have not been adequately studied, such as butterflies and ground beetles (Samways and others, 1996; Swengel, 1997). Exotic grass species were introduced in southern Texas to enhance livestock forage, and have flourished in part because of their ability to tolerate drought conditions (Hanselka and White, 1986; Ocumpaugh and Stichler, 2000). Despite their drought-tolerant benefits for livestock, exotic grasslands are considered undesirable by many natural resource managers and conservationists because of their detrimental effects on native plant species and overall plant diversity.

Historically, much of southern Texas was a landscape of verdant native prairie interrupted by occasional groves of honey mesquite or live oak (Dresser, 1865-66; Johnston, 1963; Inglis, 1964; Woodin and others, 2008), but because most prairies in southern Texas are now dominated by exotic grasses, it can be assumed that they have greater vegetation density, more grass cover, and lower plant diversity than occurred in the native prairies that existed in historical times. In addition, exotics also cause long-term changes to prairie ecosystem function. The distinct differences that exist between different components of native and exotic grasslands are evidence of different functional relationships in grassland ecosystems initiated by invasion and ultimate dominance by exotic species (Fielding and Brusven, 1993; Steffan-Dewenter and Tscharntke, 2002; Lake and Leishman, 2004). Onset of long-term changes to prairie ecosystem function by invasion of exotic grasses has been demonstrated by altered flow of energy and nutrients in the soil (Christian and Wilson, 1999), altered fire regimes (Brooks and others, 2004), and by modified rates of litter accumulation and decomposition (Ogle and Reiners, 2003).
Table 14. Comparison of avian, vegetation, and arthropod characteristics between native and exotic grasslands in southern Texas.

$[<$, less than; $\mathrm{m}$, meter $]$

\begin{tabular}{|c|c|c|c|}
\hline Characteristics & $\begin{array}{c}\text { Greater } \\
\text { in } \\
\text { natives }\end{array}$ & $\begin{array}{c}\text { No } \\
\text { difference }\end{array}$ & $\begin{array}{c}\text { Greater } \\
\text { in } \\
\text { exotics }\end{array}$ \\
\hline \multicolumn{4}{|l|}{ Avian } \\
\hline Bird numbers ${ }^{1}$ & $\mathrm{X}$ & $\mathrm{X}$ & $\mathrm{X}$ \\
\hline Bird species richness & $\mathrm{X}$ & & \\
\hline Savannah Sparrow numbers ${ }^{1}$ & $\mathrm{X}$ & $\mathrm{X}$ & $\mathrm{X}$ \\
\hline $\begin{array}{l}\text { Response of bird numbers to } \\
\text { plant diversity }\end{array}$ & & $\mathrm{X}$ & \\
\hline $\begin{array}{l}\text { Response of bird numbers to } \\
\text { vegetative structure }\end{array}$ & $\mathrm{X}$ & & \\
\hline $\begin{array}{l}\text { Response of bird species richness } \\
\text { to plant diversity }\end{array}$ & & $\mathrm{X}$ & \\
\hline $\begin{array}{l}\text { Response of bird species richness } \\
\text { to vegetative structure }\end{array}$ & $\mathrm{X}$ & & \\
\hline \multicolumn{4}{|l|}{ Vegetation } \\
\hline Grass cover & & & $\mathrm{X}$ \\
\hline Forb cover & $\mathrm{X}$ & & \\
\hline Bare ground & $\mathrm{X}$ & & \\
\hline Litter cover & & $\mathrm{X}$ & \\
\hline Shrub density & & $\mathrm{X}$ & \\
\hline Vegetation density $(<0.5 \mathrm{~m})$ & & & $\mathrm{X}$ \\
\hline Vegetation density $(0.5-1 \mathrm{~m})$ & & & $\mathrm{X}$ \\
\hline Plant species richness & $\mathrm{X}$ & & \\
\hline Seed biomass & & & $\mathrm{X}$ \\
\hline Seed diversity & $\mathrm{X}$ & & \\
\hline Environment variation explained & & $\mathrm{X}$ & \\
\hline $\begin{array}{l}\text { Contribution of vegetation } \\
\text { density to explained variation }\end{array}$ & $\mathrm{X}$ & & \\
\hline $\begin{array}{l}\text { Contribution of grass cover to } \\
\text { explained variation }\end{array}$ & $\mathrm{x}$ & & \\
\hline $\begin{array}{l}\text { Contribution of plant species } \\
\text { richness to explained variation }\end{array}$ & & & $\mathrm{X}$ \\
\hline \multicolumn{4}{|l|}{ Arthropod } \\
\hline Insect family richness & & & $\mathrm{X}^{2}$ \\
\hline Total number of insect families & $\mathrm{X}$ & & \\
\hline Insect diversity index & $\mathrm{X}$ & & \\
\hline Insect evenness & $\mathrm{X}$ & & \\
\hline Arachnid family richness & & & $\mathrm{X}$ \\
\hline Arachnid diversity index & & $\mathrm{X}$ & \\
\hline Arachnid evenness & & $\mathrm{X}$ & \\
\hline
\end{tabular}

${ }^{1}$ Variable results among multiple winters.

${ }^{2}$ In some seasons. 
Plant physiology, nutrient uptake, water dynamics, and moisture response of individual species and cultivars of exotic grasses are important areas of future research. Further research on the impacts of exotic grasses in southern latitudes is especially urgent, given the common occurrence of multiple invasive grass species across the southern tier of U.S. states and the potential for their further expansion as a direct consequence of climate change. Focus on grasslands of Texas is particularly warranted, since Samson and Knopf (1994) determined that Texas has more total area remaining in native grasslands than any other U.S. state or Canadian province within the Central Flyway. Texas ranks second in area in extant tallgrass prairies (trailing only Kansas), first in area in mixed-grass prairies, and second in area in shortgrass prairies (trailing only Wyoming). Texas supports more area in mixedgrass prairie than all other U.S. states combined (Samson and Knopf, 1994; Samson and others, 1998).

In spite of possessing these dominating statistics from a continental and regional perspective of grasslands, Texas grasslands do not prominently figure in discussions of grassland avifauna. For example, Vickery and others (1999) make little or no mention of Texas grasslands or grassland birds, nor do Askins and others (2007). In particular, coastal prairies of Texas are seldom mentioned from a national perspective of grasslands, despite the knowledge that coastal Texas is a destination for winter residents and a migration corridor for masses of Neotropical migrants. These circumstances indicate that in redressing the previous imbalance in research on winter ecology of grassland birds, the grasslands of Texas should receive special consideration.

Knopf (1994) pointed out that grassland bird conservation is a North American concern, since most grassland species do not migrate to the Neotropics. For example, Igl and Johnson (1997) determined that more than one-half of the breeding bird population of North Dakota overwintered north of the U.S.-Mexico border. Raitt and Pimm (1976) indicated that southern temperate grasslands support greater densities of birds in winter than do northern grasslands. This pattern has been reinforced with additional data from mid-temperate latitudes (Delisle and Savidge, 1997; McCoy and others, 2001).

Large numbers of grassland birds can overwinter in southern Texas grasslands, as indicated by Emlen (1972), Grzybowski (1982), and Igl and Ballard (1999), as well as in grasslands of the upper Texas coast (Heath and others, 2008). This study joins these earlier investigations in indicating that non-grassland bird species, sometimes in surprisingly large numbers, also can occur in southern Texas grasslands in winter. Emlen (1972) and Igl and Ballard (1999) reported, conversely, that rather large numbers of grassland bird species can atypically occur in winter in non-grassland habitats in southern Texas. The collective evidence provided by the present (2010) study, Emlen (1972), and Igl and Ballard (1999) indicates that birds wintering in subtropical southern Texas often can be detected using atypical habitats. This indicates that grassland bird assemblages (and perhaps others as well) are organized in winter in southern latitudes differently than are the breeding bird communities of mid- and north-temperate latitudes. Northern breeding bird communities have been studied intensively for decades and, as a result, have come to dominate our thinking on how bird assemblages are organized and regulated. Birds overwintering in subtropical grasslands, and possibly in habitats of southern latitudes in general, may be using multiple habitat types across the landscape to meet winter survival needs (Dunning and others, 1992), similar to how some migrants use habitat mosaics in the New World tropics (Petit and others, 1995). This indicates that landscape ecology will be especially important for management and conservation of the winter ranges of terrestrial bird species in southern latitudes.

\section{References Cited}

American Society of Mammalogists, 1998, Guidelines for the capture, handling, and care of mammals: The American Society of Mammalogists, Animal Care and Use Committee, accessed May 24, 2010, at http://www.mammalsociety. org/committees/index.asp.

Askins, R.A., 1993, Population trends in grassland, shrubland, and forest birds in eastern North America: Current Ornithology, v. 11, p. 1-34.

Askins, R.A., Chávez-Ramírez, F., Dale, B.C., Haas, C.A., Herkert, J.R., Knopf, F.L., and Vickery, P.D., 2007, Conservation of grassland birds in North America: understanding ecological processes in different regions: Ornithological Monographs No. 64, 46 p.

Ault, S.C., and Stormer, F.A., 1983, A suction device for sampling seed availability: Wildlife Society Bulletin, v. 11, p. $63-65$.

Avenant, N.L., 1997, Mammals recorded in the Qua-Qua National Park (1994-1995): Koedoe, v. 40, p. 131-140.

Baker, D.L., and Guthery, F.S., 1990, Effects of continuous grazing on habitat and density of ground-foraging birds in south Texas: Journal of Range Management, v. 43, p. 2-5.

Bechtoldt, C.L., and Stouffer, P.C., 2005, Home-range size, response to fire, and habitat preferences of wintering Henslow's Sparrows: Wilson Bulletin, v. 117, p. 211-225.

Beck, A.M., and Vogl, R.J., 1972, The effects of spring burning on rodent populations in a brush prairie savanna: Journal of Mammalogy, v. 53, p. 336-346.

Benkobi, L., Uresk, D.W., Schenbeck, G., and King, R.M., 2000, Protocol for monitoring standing crop in grasslands using visual obstruction: Journal of Range Management, v. 53, p. $627-633$. 
Best, L.B., Campa, H., III, Kemp, K.E., Robel, R.J., Ryan, M.R., Savidge, J.A., Weeks, H.P., Jr., and Winterstein, S.R., 1998, Avian abundance in CRP and crop fields during winter in the Midwest: American Midland Naturalist, v. 139, p. 311-324.

Bock, C.E., and Bock, J.H., 1992, Response of birds to wildfire in native versus exotic Arizona grassland: Southwestern Naturalist, v. 37, p. 73-81.

Bock, C.E., and Bock, J.H., 1998, Response of winter birds to drought and short-duration grazing in southeastern Arizona: Conservation Biology, v. 13, p. 1,117-1,123.

Bock, C.E., Bock, J.H., Jepson, K.L., and Ortega, J.C., 1986, Ecological effects of planting African lovegrasses in Arizona: National Geographic Research, v. 2, p. 456-463.

Bollinger, E.K., 1995, Successional changes and habitat selection in hayfield bird communities: Auk, v. 112, p. 720-730.

Bookhout, T.A., 1958, The availability of plant seeds to bobwhite quail in southern Illinois: Ecology, v. 39, p. 671-681.

Borror, D.J., and White, R.E., 1970, Peterson field guideInsects: Boston, Houghton Mifflin Harcourt Publishing Co., $362 \mathrm{p}$.

Bourn, N.A.D., and Thomas, J.A., 2002, The challenge of conserving grassland insects at the margins of their range in Europe: Biological Conservation, v. 104, p. 285-292.

Bowden, C.G.R., 1990, Selection of foraging habitats by Woodlarks (Lullula arborea) nesting in pine plantations: Journal of Applied Ecology, v. 27, p. 410-419.

Brady, M.J., and Slade, N.A., 2001, Diversity of a grassland rodent community at varying temporal scales - The roles of ecologically dominant species: Journal of Mammalogy, v. 82, p. 974-983.

Brennan, L.A., and Kuvlesky, W.P., Jr., 2005, North American grassland birds - An unfolding conservation crisis?: Journal of Wildlife Management, v. 69, p. 1-13.

Brooks, M.L., D’Antonio, C.M., Richardson, D.M., Grace, J.B., Keeley, J.E., DiTomaso, J.M., Hobbs, R.J., Pellant, M., and Pyke, D., 2004, Effects of invasive alien plants on fire regimes: BioScience, v. 54, p. 677-688.

Browder, S.F., Johnson, D.H., and Ball, I.J., 2002, Assemblages of breeding birds as indicators of grassland condition: Ecological Indicators, v. 2, p. 257-270.

Cameron, G.N., and Bryant, E.H., 1999, Species composition and trophic structure of insect communities in Texas prairies: Prairie Naturalist, v. 31, p. 221-242.

Cameron, G.N., and Kruchek, B.L., 2005, Use of coastal wetlands by hispid cotton rats (Sigmodon hispidus): Southwestern Naturalist, v. 50, p. 397-402.
Canters, K.J., and Tamis, W.L.M., 1999, Arthropods in grassy field margins in the Wieringermeer Scope, population development and possible consequences for farm practice: Landscape and Urban Planning, v. 46, p. 63-69.

Carmona, D.M., 1998, Influence of refuge habitats on seasonal activity-density of ground beetles (Coleoptera: Carabidae) and northern field cricket Gryllus pennsylvanicus Burmeister (Orthoptera: Gryllidae): Lansing, Mich., Michigan State University, Master of Science thesis, 106 p.

Carrie, N.R., Wagner, R.O., Moore, K.R., Sparks, J.C., Keith, E.L., and Melder, C.A., 2002, Winter abundance of and habitat use by Henslow's Sparrows in Louisiana: Wilson Bulletin, v. 114, p. 221-226.

Christian, J.M., and Wilson, S.D., 1999, Long-term ecosystem impacts of an introduced grass in the northern Great Plains: Ecology, v. 80, p. 2,397-2,407.

Churchill, T.B., and Arthur, J.M., 1999, Measuring spider richness - Effects of different sampling methods and spatial and temporal scales: Journal of Insect Conservation, v. 3, p. 287-295.

Clarke, P.J., Latz, P.K., and Albrecht, D.E., 2005, Long-term changes in semi-arid vegetation: invasion of an exotic perennial grass has larger effects than rainfall variability: Journal of Vegetation Science, v. 16, p. 237-248.

Cody, M.L., 1968, On the methods of resource division in grassland bird communities: American Naturalist, v. 102, p. 107-147.

Cody, M.L., 1974, Competition and the structure of bird communities: Monographs in Population Biology No. 7, Princeton, N.J., Princeton University Press, 318 p.

Collinge, S.K., and Forman, R.T.T., 1998, A conceptual model of land conversion process-Predictions and evidence from a microlandscape experiment with grassland insects: Oikos, v. 82 , p. $66-84$

Cook, S.F., Jr., 1959, The effects of fire on a small population of small rodents: Ecology, v. 40, p. 102-108.

Daubenmire, R.F., 1959, A canopy coverage method of vegetational analysis: Northwest Science, v. 35, p. 43-64.

Daubenmire, R., 1978, Plant geography, with special reference to North America: New York, Academic Press, 338 p.

Dauber, J., Hirsch, M., Simmering, D., Waldhardt, R., Otte, A., and Wolters, V., 2003, Landscape structure as an indicator of biodiversity-Matrix effects on species richness: Agriculture, Ecosystems \& Environment, v. 98, p. 321-329. 
Davis, S.K., and Duncan, D.C., 1999, Grassland songbird occurrence in native and crested wheatgrass pastures of southern Saskatchewan: Studies in Avian Biology, v. 19, p. 211-218.

Dechant, J.A., Sondreal, M.L., Johnson, D.H., Igl, L.D., Goldade, C.M., Parkin, B.D., and Euliss, B.R., 2003, Effects of management practices on grassland birds - Sedge Wren: Jamestown, N. Dak, Northern Prairie Wildlife Research Center, accessed October 5, 2009, at http://www.npwrc.usgs. gov/resource/literatr/grasbird/sewr/sewr.htm.

Delisle, J.M., and Savidge, J.A., 1997, Avian use and vegetation characteristics of Conservation Reserve Program fields: Journal of Wildlife Management, v. 61, p. 318-325.

Dennis, J.F., and Brusven, M.A., 1993, Spatial analysis of grasshopper density and ecological disturbance on southern Idaho rangeland: Agriculture, Ecosystems \& Environment, v. 43 , p. $31-47$.

Dennis, P., Young, M.R., and Bentley, C., 2001, The effects of varied grazing management on epigeal spiders, harvestmen and pseudoscorpions of Nardus stricta grassland in upland Scotland: Agriculture, Ecosystems \& Environment, v. 86, p. $39-57$.

Desmond, M.J., Mendez-Gonzalez, C., and Abbott, L.B., 2008, Winter diets and seed selection of granivorous birds in southwestern New Mexcio in Ruth, J., Brush, T., and Krueper, D., eds., Birds of the U.S.-Mexico borderlandsDistribution, ecology, and conservation: Studies in Avian Biology No. 37, p. 101-112.

DeVos, A., and Mosby, H.S., 1971, Habitat analysis and evaluation in Giles, R.H., Jr., ed., Wildlife management techniques ( $3 \mathrm{~d}$ ed., revised): Washington, D.C., The Wildlife Society, p. 135-172.

DiMiceli, J.K., Stouffer, P.C., Johnson, E.I., Leonardi, C., and Moser, E.B., 2007, Seed preferences of wintering Henslow's Sparrows: Condor, v. 109, p. 595-604.

Dresser, H.E., 1865-1866, Notes on the birds of southern Texas: Ibis, v. 1, p. 312-330, 466-495; v. 2, p. 23-46.

Droste, T., Flory, S.L., and Clay, K., 2009, Variation for phenotypic plasticity among populations of an invasive exotic grass: Plant Ecology, DOI 10.1007/s11258-009-9673-5.

Duffey, E., Morris, M.G., Sheail, J., Ward, L.K., Wells, D.A., and Wells, T.C.E., 1974, Grassland ecology and wildlife management; the use of fire, fertilizers and herbicides in management: London, Chapman and Hall, 281 p.

Dunning, J.B., Danielson, B.J., and Pulliam, H.R., 1992, Ecological processes that affect populations in complex landscapes: Oikos, v. 65, p. 169-175.
Eitniear, J.C., 2004, Diet of the White-collared Seedeater Sporophila torqueola (Passeriformes: Emberizidae) in Texas: Texas Journal of Science, v. 56, p. 77-81.

Eitniear, J.C., 2007, Feeding ecology of White-collared Seedeaters at Zapata County Park: Bulletin of the Texas Ornithological Society, v. 40, p. 80-82.

Emlen, J.T., 1972, Size and structure of a wintering avian community in southern Texas: Ecology, v. 53, p. 317-329.

Fielding, D.J., and Brusven, M.A., 1993, Grasshopper (Orthoptera: Acrididae) community composition and ecological disturbance on southern Idaho rangeland: Community and Ecosystem Ecology, v. 22, p. 71-81.

Fischer, F.P., Schulz, U., Schubert, H., Knapp, P., and Schmoger, M., 1997, Quantitative assessment of grassland quality: acoustic determination of population sizes of orthopteran indicator species: Ecological Applications, v. 7, p. 909-920.

Flanders, A.A., 2003, Impacts of invasive exotic grasses on south Texas bird communities: Kingsville, Tex., Texas A\&M University-Kingsville, Master of Science thesis, $70 \mathrm{p}$.

Flanders, A.A., Kuvlesky, W.P., Jr., Ruthven, D.C., III, Zaiglin, R.E., Bingham, R.L., Fulbright, T.E., Hernández, F., and Brennan, L.A., 2006, Effects of invasive exotic grasses on south Texas rangeland breeding birds: Auk, v. 123, p. 171182.

Forde, J.D., Sloan, N.F., and Shown, D.A., 1984, Grassland habitat management using prescribed burning in Wind Cave National Park, South Dakota: Prairie Naturalist, v. 16, p. 97-110.

Fritcher, S.C., Rumble, M.A., and Flake, L.D., 2004, Grassland bird densities in seral stages of mixed-grass prairie: Rangeland Ecology and Management, v. 57, p. 351-357.

Fulbright, T.E., and Bryant, F.C., 2002, The last great habitat: Kingsville, Tex., Caesar Kleberg Wildlife Research Institute, Texas A\&M University-Kingsville, Special publication No. 1.

Fulbright, T.E. and Hewitt, D.G., 2007, Effects of drought on bobcats and ocelots in Fulbright, T.E., and Hewitt, D.G., eds., Wildlife science - Linking ecological theory and management applications: New York, CRC Press, p. 126-127.

Gillespie, S.C., Van Vuren, D.H., Kelt, D.A., Eadie, J.M., and Anderson, D.W., 2008, Dynamics of rodent populations in semi-arid habitats in Lassen County, California: Western North American Naturalist, v. 68, p. 76-82.

Ginter, D.L., and Desmond, M.J., 2005, Influence of foraging and roosting behavior on home-range size and movement patterns of Savannah Sparrows wintering in south Texas: Wilson Bulletin, v. 117, p. 63-71. 
Gordon, C.E., 2000, Movement patterns of wintering grassland sparrows in Arizona: Auk, v. 117, p. 748-759.

Gould, F.W., Hoffman, G.O., and Rechenthin, C.A., 1960, Vegetational areas of Texas: College Station, Tex., Texas A\&M University, Texas Agricultural Experiment Station, Leaflet No. 492.

Grant, T.A., Madden, E., and Berkey, G.B., 2004, Tree and shrub invasion in northern mixed-grass prairie-Implications for breeding grassland birds: Wildlife Society Bulletin, v. 32 , p. $807-818$.

Grzybowski, J.A., 1982, Population structure in grassland bird communities during winter: Condor, v. 84, p. 137-151.

Grzybowski, J.A., 1983, Patterns of space use in grassland bird communities during winter: Wilson Bulletin, v. 95, p. 591-602.

Hamel, P.B., Smith, W.P., Twedt, D.J., Woehr, J.R., Morris, E., Hamilton, R.B., and Cooper, R.J., 1996, A land manager's guide to point counts of birds in the southeast: New Orleans, La., U.S. Department of Agriculture, Forest Service, Southern Research Station, General Technical Report SO-12, 39 p.

Hanselka, C.W., and White, L.D., 1986, Rangeland in dry years: drought effects on range, cattle, and management in Brown, R.D., ed., Livestock and wildlife management during drought: Kingsville, Tex., Caesar Kleberg Wildlife Research Institute, p. 47-58.

Hatch, S.L., Gandhi, K.N., and Brown, L.E., 1990, Checklist of the vascular plants of Texas: College Station, Tex., Texas Agricultural Experiment Station, MP-1655, 158 p.

Hatch, S.L., Schuster, J.L., and Drawe, D.L., 1999, Grasses of the Texas gulf prairies and marshes: College Station, Tex., Texas A\&M University Press, 355 p.

Haukos, D.A., Sun, H.Z., Wester, D.B., and Smith, L.M., 1998, Sample size, power, and analytical considerations for vertical structure data from profile boards in wetland vegetation: Wetlands, v. 18, p. 203-215.

Heath, S.A., Shackelford, C.E., and Riley, C.M., 2008, Project Prairie Birds - A citizen science project for wintering grassland birds: Bulletin of the Texas Ornithological Society, v. 41, p. 51-59.

Herkert, J.R., 1995, An analysis of midwestern breeding bird population trends: 1966-1993: American Midland Naturalist, v. 134 , p. 41-50.

Herkert, J.R., 1998, The influence of the CRP on Grasshopper Sparrow population trends in the mid-continental United States: Wildlife Society Bulletin, v. 26, p. 227-231.
Herkert, J.R., and Knopf, F.L., 1998, Research needs for grassland bird conservation in Marzluff, J.M., and Sallabanks, R., eds., Avian conservation-Research and management: Washington, D.C., Island Press, p. 273-282.

Herkert, J.R., Kroodsma, D.E., and Gibbs, J.P., 2001, Sedge Wren (Cistothorus platensis) in Poole, A., and Gill, F., eds., The Birds of North America No. 582, Philadelphia: Washington, D.C., The Academy of Natural Sciences, The American Ornithologists' Union, 20 p.

Herkert, J.R., Reinking, D.L., Wiedenfeld, D.A., Winter, M., Zimmerman, J.L., Jensen, W.E., Finck, E.J., Koford, R.R., Wolfe, D.H., Sherrod, S.K., Jenkins, M.A., Faaborg, J., and Robinson, S.K., 2003, Effects of prairie fragmentation on the nesting success of breeding birds in the midcontinental United States: Conservation Biology, v. 17, p. 587-594.

Hickman, K.R., Farley, G.H., Channell, R., and Steier, J.E., 2006, Effects of old world bluestem (Bothriochloa ischaemum) on food availability and avian community composition within the mixed-grass prairie: Southwestern Naturalist, v. 51, p. 524-530.

Houston, C.S., and Schmutz, J.K., 1999, Changes in bird populations on Canadian grasslands: Studies in Avian Biology, v. 19, p. 87-94.

Hughes, J.P., Robel, R.J., Kemp, K.E., and Zimmerman, J.L., 1999, Effects of habitat on Dickcissel abundance and nest success in Conservation Reserve Program fields in Kansas: Journal of Wildlife Management, v. 63, p. 523-529.

Hulme, P.E., 1996, Herbivores and the performance of grassland plants - A comparison of arthropod, mollusc and rodent herbivory: Journal of Ecology, v. 84, p. 43-51.

Igl, L.D., and Ballard, B.M., 1999, Habitat associations of migrating and overwintering grassland birds in southern Texas: Condor, v. 101, p. 771-782.

Igl, L.D., and Johnson, D.H., 1997, Changes in breeding bird populations in North Dakota, 1967 to 1992-93: Auk, v. 114, p. 74-92.

Inglis, J.M., 1964, A history of vegetation on the Rio Grande plain: Austin, Tex., Texas Parks and Wildlife Department Bulletin No. 45.

Integrated Taxonomic Information System, 2006, accessed July 11, 2006, at http://www.itis.gov/.

Johnsgard, P.A., 1964, Comparative behavior and relationships of the eiders: Condor, v. 66, p. 113-129.

Johnson, D.H., 1997, Effects of fire on bird populations in mixed-grass prairie in Knopf, F.L., and Samson, F.B., eds., Ecology and conservation of Great Plains vertebrates: New York, Springer-Verlag, p. 181-206. 
Johnston, M.C., 1963, Past and present grasslands of southern Texas and northeastern Mexico: Ecology, v. 44, p. 456-466.

Jones, Z.F., Bock, C.E., and Bock, J.H., 2003, Rodent communities in a grazed and ungrazed Arizona grassland, a model of habitat relationships among rodents in southwest grass/shrublands: American Midland Naturalist, v. 149, p. 384-392.

Kaspari, M., and Joern, A., 1993, Prey choice by three insectivorous grassland birds-Reevaluating opportunism: Oikos, v. 68, p. 414-430.

Killgore, A., Jackson, E., and Whitford, A.G., 2009, Fire in Chihuahuan Desert grassland-Short-term effects on vegetation, small mammal populations, and faunal pedoturbation: Journal of Arid Environments, v. 73, p. 1,029-1,034.

King, J.W., and Savidge, J.A., 1995, Effects of the Conservation Reserve Program on wildlife in southeast Nebraska: Wildlife Society Bulletin, v. 23, p. 377-385.

Kirkpatrick, C., DeStefano, S., Mannan, R.W., and Lloyd, J., 2002, Trends in abundance of grassland birds following a spring prescribed burn in southern Arizona: Southwestern Naturalist, v. 47, p. 282-292.

Klute, D.S., Robel, R.J., and Kemp, K.E., 1997, Seed availability in grazed pastures and Conservation Reserve Program fields during winter in Kansas: Journal of Field Ornithology, v. 68, p. 253-258.

Knopf, F.L., 1994, Avian assemblages on altered grasslands: Studies in Avian Biology, v. 15, p. 247-257.

Kruess, A., and Tscharntke, T., 2002, Contrasting responses of plant and insect diversity to variation in grazing intensity: Biological Conservation, v. 106, p. 293-302.

Kruskal, W.H., and Wallis, W.A., 1952, Use of ranks in onecriterion variance analysis: Journal of the American Statistical Association, v. 47, p. 583-621.

Lake, J.C., and Leishman, M.R., 2004, Invasion success of exotic plants in natural ecosystems - The role of disturbance, plant attributes and freedom from herbivores: Biological Conservation, v. 117 , p. 215-226.

Lambdin, P.L., Grant, J.F., Wiggins, G.J., and Saxton, A., 2003, Diversity of the true bugs (Hemiptera: Heteroptera) on Arnold Air Force Base, Tullahoma, Tennessee: Journal of the Tennessee Academy of Science, v. 78, p. 76-84.

Lawrence, G.E., 1966, Ecology of vertebrate animals in relation to chaparral in the Sierra Nevada Foothills: Ecology, v. 47 , p. 278-291.

Lawton, J.H., and Strong, D.R., Jr., 1981, Community patterns and competition in folivorous insects: American Naturalist, v. 118 , p. $317-338$.
Lehmann, V.W., 1969, Forgotten legions: sheep in the Rio Grande Plain of Texas: El Paso, Tex., Texas Western Press, The University of Texas-El Paso, 226 p.

Lemen, C.A., and Clausen, M.K., 1984, The effects of mowing on the rodent community of a native tall grass prairie in eastern Nebraska: Prairie Naturalist, v. 16, p. 5-10.

Leopold, A.S., 1950, Vegetation zones of Mexico: Ecology, v. 31, p. 507-518.

Littles, C.J., Williford, D., Skoruppa, M.K., Woodin, M.C., and Hickman, G.C., 2007, Diet of western burrowing owls wintering in southern Texas: Journal of Raptor Research, v. 41, p. 307-313.

Lloyd, J., Mannan, R.W., Destefano, S., and Kirkpatrick, C., 1998, The effects of mesquite invasion on a southeastern Arizona grassland bird community: Wilson Bulletin, v. 110, p. 403-408.

Lloyd, J.D., and Martin, T.E., 2005, Reproductive success of Chestnut-collared Longspurs in native and exotic grassland: Condor, v. 107, p. 363-374.

Long, D.B., 2005, Effects of exotic grasses on small mammals and invertebrates in southern Texas: Kingsville, Tex., Texas A\&M University-Kingsville, Master of Science thesis, $86 \mathrm{p}$.

Long, D.B., and Henke, S.E., 2004, Mammalian and herptile survey results for NAS-Kingsville, NALF-Orange Grove, and Escondido Ranch: Kingsville, Tex., Caesar Kleberg Wildlife Research Institute, 90 p.

MacArthur, R.H., 1958, Population ecology of some warblers of northeastern coniferous forests: Ecology, v. 39, p. 599619.

MacArthur, R.H., and MacArthur, J.W., 1961, On bird species diversity: Ecology, v. 42, p. 594-598.

Mann, H.B., and Whitney, D.R., 1947, On a test of whether one of two random variables is stochastically larger than the other: Annals of Mathematical Statistics, v. 18, p. 50-60.

Martin, J.M., Heske, E.J., and Hofmann, J.E., 2003, Franklin's ground squirrel (Spermophilus franklinii) in Illinois-A declining prairie mammal?: American Midland Naturalist, v. 150 , p. $130-138$.

McCoy, T.D., Ryan, M.R., Burger, L.W., Jr., and Kurzejeski, E.W., 2001, Grassland bird conservation-CP1 vs. CP2 plantings in Conservation Reserve Program fields in Missouri: American Midland Naturalist, v. 145, p. 1-17.

McIntyre, N.E., and Thompson, T.R., 2003, A comparison of Conservation Reserve Program habitat plantings with respect to arthropod prey for grassland birds: American Midland Naturalist, v. 150, p. 291-301. 
McKinney, F., 1970, Displays of four species of blue-winged ducks: Living Bird, v. 9, p. 29-64.

Milne, L.J., Milne, M., and Rayfield, S., 1980, National Audubon Society field guide to North American insects and spiders: New York, Knopf Doubleday Publishing Group, $992 \mathrm{p}$.

Milroy, A.G., 2007, Impacts of mowing on bird abundance, disturbance, and hazards to aircraft at Westover Air Reserve Base, Massachusetts: Amherst, Mass., University of Massachusetts, Master of Science thesis, $46 \mathrm{p}$.

Mortimer, S.R., Booth, R.G., Harris, S.J., and Brown, V.K., 2002, Effects of initial site management on the Coleoptera assemblages colonizing newly established chalk grassland on ex-arable land: Biological Conservation, v. 104, p. 301313.

Mueller-Dombois, D., and Ellenberg, H., 1974, Aims and methods of vegetation ecology: New York, John Wiley \& Sons, Inc., 547 p.

National Climatic Data Center, 2003, Climatological data annual summary Texas: Asheville, N.C., National Oceanic and Atmospheric Administration, v. 108, no. 13, 76 p., accessed August 5, 2009, at http://www7.ncdc.noaa.gov/ IPS/cd/cd.html.

National Climatic Data Center, 2004, Climatological data annual summary Texas: Asheville, N.C., National Oceanic and Atmospheric Administration, v. 109, no. 13, 74 p., accessed August 5, 2009, at http://www7.ncdc.noaa.gov/ IPS/cd/cd.html.

National Climatic Data Center, 2005, Climatological data annual summary Texas: Asheville, N.C., National Oceanic and Atmospheric Administration, v. 110, no. 13, 94 p., accessed August 5, 2009, at http://www7.ncdc.noaa.gov/ IPS/cd/cd.html.

National Climatic Data Center, 2006, Climatological data annual summary Texas: Asheville, N.C., National Oceanic and Atmospheric Administration, v. 111, no. 13, 94 p., accessed August 5, 2009, at http://www7.ncdc.noaa.gov/ $\mathrm{IPS} / \mathrm{cd} / \mathrm{cd}$.html.

National Climatic Data Center, 2007, Climatological data annual summary Texas: Asheville, N.C., National Oceanic and Atmospheric Administration, v. 112, no. 13, 88 p., accessed August 5, 2009, at http://www7.ncdc.noaa.gov/ IPS/cd/cd.html.

Natural Resources Conservation Service, 2008, General soil map of Texas: Temple, Tex., U.S. Department of Agriculture, accessed December 15, 2009, at http://www.tx.nrcs. usda.gov/soil/index.html.

Nelle, S., 1992, Exotics - At home on the range in Texas: Rangelands, v. 14, p. 77-80.
Nudds, T.D., 1977, Quantifying the vegetative structure of wildlife cover: Wildlife Society Bulletin, v. 5, p. 113-117.

Ocumpaugh, W.R., and Stichler, C., 2000, Introduced forages for south and south central Texas: College Station, Tex., Texas Agricultural Extension Service, SCS-2000-25, 8 p., accessed August 7, 2009, at http:/fforagesoftexas.tamu.edu/ pdf/introducedforages.pdf.

Ogle, S.M., and Reiners, W.A., 2003, Impacts of exotic annual brome grasses (Bromus spp.) on ecosystem properties of northern mixed grass prairie: American Midland Naturalist, v. 149 , p. $46-58$.

Oliver, I., and Beattie, A.J., 1996, Invertebrate morphospecies as surrogates for species-A case study: Conservation Biology, v. 10, p. 99-109.

Pearce, B.D., 2007, Insect assemblages in native- and exoticdominant grasslands in southern Texas: Corpus Christi, Tex., Texas A\&M University-Corpus Christi, Master of Science thesis, $63 \mathrm{p}$.

Peterjohn, B.G., and Sauer, J.R., 1999, Population status of North American grassland birds from the North American Breeding Bird Survey 1966-1996: Studies in Avian Biology, v. 19, p. 27-44.

Petit, D.R., Lynch, J.F., Hutto, R.L., Blake, J.G., and Waide, R.B., 1995, Habitat use and conservation in the tropics in Martin, T.E., and Finch, D.M., eds., Ecology and management of Neotropical migratory birds - A synthesis and review of critical issues: New York, Oxford University Press, p. 145-197.

Plentovich, S., Holler, N.R., and Hill, G.E., 1999, Habitat requirements of Henslow's Sparrows wintering in silvicultural lands of the Gulf Coastal Plain: Auk, v. 116, p. 109115.

Pulliam, H.R., 1980, Do Chipping Sparrows forage optimally?: Ardea, v. 68 , p. $75-82$.

Pulliam, H.R., 1985, Foraging efficiency, resource partitioning, and the coexistence of sparrow species: Ecology, v. 66, p. $1,829-1,836$.

Pulliam, H.R., and Dunning, J.B., 1987, The influence of food supply on local density and diversity of sparrows: Ecology, v. 68 , p. $1,009-1,014$.

Pulliam, H.R., and Mills, G.S., 1977, The use of space by wintering sparrows: Ecology, v. 58, p. 1,393-1,399.

Pulliam, H.R., and Parker, T.A., III, 1979, Population regulation of sparrows: Fortschritte der Zoologie, v. 25, p. 137-147. 
Raitt, R.J., and Pimm, S.L., 1976, Dynamics of bird communities in the Chihuahuan Desert, New Mexico: Condor, v. 78, p. 427-442.

Ralph, C.J., Geupel, G.R., Pyle, P., Martin, T.E., and DeSante, D.F., 1993, Handbook of field methods for monitoring landbirds: Albany, Calif., U.S. Department of Agriculture, Forest Service, Pacific Southwest Research Station, General Technical Report PSW-GTR-144, 41 p.

Rambo, J.L., and Faeth, S.H., 1999, Effect of vertebrate grazing on plant and insect community structure: Conservation Biology, v. 13, p. 1,047-1,054.

Ramos, M.G., and Plocheck, R., eds., 1997, 1998-1999 Texas almanac: Dallas, Tex., Dallas Morning News, Inc., 672 p.

Rappole, J.H., and Blacklock, G.W., 1985, Birds of the Texas Coastal Bend, abundance and distribution: College Station, Tex., Texas A\&M University Press, 126 p.

Rappole, J.H., and Blacklock, G.W., 1994, A field guide to the birds of Texas: College Station, Tex., Texas A\&M University Press, 280 p.

Rappole, J.H., Russell, C.E., Norwine, J.R., and Fulbright, T.E., 1986, Anthropogenic pressures and impacts on marginal, Neotropical, semiarid systems - The case of south Texas: Science of Total Environment, v. 55, p. 91-99.

Reed, A.W., Kaufman, G.A., and Kaufman, D.W., 2004, Influence of fire, topography, and consumer abundance on seed predation in tallgrass prairie: Canadian Journal of Zoology, v. 82 , p. $1,459-1,467$.

Reynolds, M.C., and Krausman, P.R., 1998, Effects of winter burning on birds in mesquite grassland: Wildlife Society Bulletin, v. 26, p. 867-876.

Richards, C.L., Bossdorf, O., Muth, N.Z., Gurevitch, J., and Pigliucci, M., 2006, Jack of all trades, master of some? On the role of phenotypic plasticity in plant invasions: Ecology Letters, v. 9, p. 981-993.

Ripley, T.H., and Perkins, C.J., 1965, Estimating ground supplies of seed available to bobwhites: Journal of Wildlife Management, v. 29, p. 117-121.

Robel, R.J., Briggs, J.N., Dayton, A.D., and Hulbert, L.C., 1970, Relationship between visual obstruction measurements and weight of grassland vegetation: Journal of Range Management, v. 23, p. 295-297.

Robel, R.J., and Slade, N.A., 1965, The availability of sunflower and ragweed seeds during fall and winter: Journal of Wildlife Management, v. 29, p. 202-206.

Roberts, J.P., and Schnell, G.D., 2006, Comparison of survey methods for wintering grassland birds: Journal of Field Ornithology, v. 77, p. 46-60.
Ruddy, A.J., 2009, Responses of rodent and grassland bird populations to mowing and controlled burns: Corpus Christi, Tex., Texas A\&M University-Corpus Christi, Master of Science thesis, $49 \mathrm{p}$.

Samson, F.B., and Knopf, F.L., 1994, Prairie conservation in North America: BioScience, v. 44, p. 418-421.

Samson, F.B., Knopf, F.L., and Ostlie, W.R., 1998, Grasslands, in Mac, M.J., Opler, P.A., Puckett Haecker, C.E., and Doran, P.D., eds., Status and trends of the nation's biological resources, v. 2: Jamestown, N. Dak., Northern Prairie Wildlife Research Center, p. 437-472. Online version 21JAN2000, accessed February 9, 2010, at http://www. npwrc.usgs.gov/resource/habitat/grlands/index.htm.

Samways, M.J., Caldwell, P.M., and Osborn, R., 1996, Ground-living invertebrate assemblages in native, planted and invasive vegetation in South Africa: Agriculture, Ecosystems \& Environment, v. 59, p. 19-32.

Sands, J.P., Brennan, L.A., Hernández, F., Kuvlesky, W.P., Jr., Gallagher, J.F., Ruthven, D.C., III, and Pittman, J.E., III, 2009, Impacts of buffelgrass (Pennisetum ciliare) on a forb community in South Texas: Invasive Plant Science and Management, v. 2, p. 130-140.

Sauer, J.R., Hines, J.E., and Fallon, J., 2008, The North American Breeding Bird Survey, results and analysis 1966-2007: U.S. Geological Survey, version 5.15.2008, accessed July 27, 2009, at http://www.mbr-pwrc.usgs.gov/bbs/bbs.html.

Schmidly, D.J., 2002, Texas natural history-A century of change: Lubbock, Tex., Texas Tech University Press, 534 p.

Schmidly, D.J., 2004, The mammals of Texas (revised edition): Austin, Tex., University of Texas Press, 544 p.

Senzota, R.B.M., 1985, Effects of prescribed burning on a small mammal community in Post Oak Savannah, Texas: College Station, Tex., Texas A\&M University, Ph.D. dissertation, $105 \mathrm{p}$.

Shackelford, C.E., Carrie, N.R., Riley, C.M., and Carrie, D.K., 2001, Project Prairie Birds - A citizen science project for wintering grassland birds: Austin, Tex., Texas Parks and Wildlife Department, PWD BK W7000-485 (1/01), 24 p.

Shannon, C.E., 1948, A mathematical theory of communication: Bell System Technical Journal, v. 27, p. 379-423 and p. $623-656$.

Shapiro, S.S., and Wilk, M.B., 1965, An analysis of variance test for normality (complete samples): Biometrika, v. 52, p. 591-611.

Sibley, D.A., 2000, The Sibley guide to birds: New York, Alfred A. Knopf, Inc., 544 p. 
Slade, N.A., and Crain, S., 2006, Impact on rodents of mowing strips in old fields of eastern Kansas: Journal of Mammalogy, v. 87, p. 97-101.

Smeins, F.E., Diamond, D.D., and Hanselka, C.W., 1991, Coastal prairie, in Coupland, R.T., ed., Ecosystems of the world, 8A. Natural grasslands; introduction and western hemisphere: New York, Elsevier, p. 269-290.

Smith, R.L., 1980, Terrestrial Ecosystems I-Distribution, soil, grasslands, shrublands, deserts in Nickol, D., ed., Ecology and field biology: New York, Harper \& Row Publishers, p. 272-309.

Steffan-Dewenter, I., and Tscharntke, T., 2002, Insect communities and biotic interactions on fragmented calcareous grasslands-A mini review: Biological Conservation, v. 104, p. 275-284.

Stein, B.A., Scott, C., and Benton, N., 2008, Federal lands and endangered species - The role of military and other federal lands in sustaining biodiversity: BioScience, v. 58, p. 339-347.

Stokes, M.K., 1995, Selection of refuge sites by sympatric Microtus ochrogaster and Sigmodon hispidus: Journal of Mammalogy, v. 76, p. 83-87.

Student, 1908, The probable error of a mean: Biometrika, v. 6, p. $1-25$.

Sutter, G.C., and Brigham, R.M., 1998, Avifaunal and habitat changes resulting from conversion of native prairie to crested wheat grass-Patterns at songbird community and species levels: Canadian Journal of Zoology, v. 76, p. 869-875.

Swengel, A.B., 1997, Effects of management on butterfly abundance in tallgrass prairie and pine barrens: Biological Conservation, v. 83, p. 77-89.

Swengel, S.R., and Swengel, A.B., 1999, Correlations in abundance of grassland songbirds and prairie butterflies: Biological Conservation, v. 90, p. 1-11.

Texas Parks and Wildlife Department, 2005, Texas Wildlife Action Plan, Comprehensive Wildlife Conservation Strategy: Austin, Tex., Texas Parks and Wildlife Department, 1,131 p., accessed September 29, 2009, at http://www.tpwd. state.tx.us/publications/pwdpubs/pwd_pl_w7000_1187a/.

Thompson, D.B., Brown, J.H., and Spencer, W.D., 1991, Indirect facilitation of granivorous birds by desert rodents: experimental evidence from foraging patterns: Ecology, v. 72 , p. $852-863$.

Thompson, T.R., Boal, C.W., and Lucia, D., 2009, Grassland bird associations with introduced and native grass Conservation Reserve Program fields in the Southern High Plains: Western North American Naturalist, v. 69, p. 481-490.
Toledo, D., Abbott, L.B., and Herrick, J.E., 2008, Cover pole design for easy transport, assembly, and field use: Journal of Wildlife Management, v. 72, p. 564-567.

Tucker, J.W., Jr., and Robinson, W.D., 2003, Influence of season and frequency of fire on Henslow's Sparrows (Ammodramus henslowii) wintering on Gulf Coast pitcher plant bogs: Auk, v. 120, p. 96-106.

Twedt, D.J., Hamel, P.B., and Woodrey, M.S., 2008, Winter bird population studies and Project Prairie Birds for surveying grassland birds: Southeastern Naturalist, v. 7, p. 11-18.

U.S. Department of the Navy, 2002a, Integrated Natural Resource Management Plan-Naval Air Station-Corpus Christi/Waldron, Texas: Corpus Christi, Tex., U.S. Department of Defense.

U.S. Department of the Navy, 2002b, Integrated Natural Resource Management Plan-Naval Air Station-Kingsville, Texas: Kingsville, Tex., U.S. Department of Defense.

U.S. Fish and Wildlife Service, 2008, Birds of Conservation Concern 2008: Arlington, Va., U.S. Department of Interior, U.S. Fish and Wildlife Service, Division of Migratory Bird Management, 85 p., accessed July 30, 2009, at http://www. fws.gov/migratorybirds/.

Vickery, J.A., Tallowin, J.R., Feber, R.E., Asteraki, E.J., Atkinson, P.W., Fuller, R.J., and Brown, V.K., 2001, The management of lowland neutral grasslands in Britain-Effects of agricultural practices on birds and their food resources: Journal of Applied Ecology, v. 38, p. 647-664.

Vickery, P.D., and Herkert, J.R., 2001, Recent advances in grassland bird research-Where do we go from here?: Auk, v. 118, p. 11-15.

Vickery, P.D., Herkert, J.R., Knopf, F.L., Ruth, J., and Keller, C.E., 2000, Grassland birds-An overview of threats and recommended management strategies in Bonney, R., Pashley, D.N., Cooper, R.J., and Niles, L., eds., Strategies for bird conservation - The Partners in Flight planning process: Ogden, Utah, U.S. Department of Agriculture, Forest Service, Rocky Mountain Research Station, RMRS-P-16, p. 74-77.

Vickery, P.D., Tubaro, P.L., Da Silva, J.M.C., Peterjohn, B.G., Herkert, J.R., and Cavalcanti, R.B., 1999, Conservation of grassland birds in the Western Hemisphere: Studies in Avian Biology, v. 19, p. 2-26.

Wiegert, R.G., 1972, Avian versus mammalian predation on a population of cotton rats: Journal of Wildlife Management, v. 36 , p. $1,322-1,327$.

Wiens, J.A., 1973, Pattern and process in grassland bird communities: Ecological Monographs, v. 43, p. 237-270. 
Wiens, J.A., and Rotenberry, J.T., 1979, Diet niche relationships among North American grassland and shrubsteppe birds: Oecologia, v. 42, p. 253-292.

Wight, H.M., 1938, Field and laboratory techniques in wildlife management: Ann Arbor, University of Michigan Press, $108 \mathrm{p}$.

Wilcove, D.S., Rothstein, D., Dubow, J., Phillips, A., and Losos, E., 1998, Quantifying threats to imperiled species in the United States: BioScience, v. 48, p. 607-615.

Wilson, S.D., and Belcher, J.W., 1989, Plant and bird communities of native prairie and introduced Eurasian vegetation in Manitoba, Canada: Conservation Biology, v. 3, p. 39-44.
Winter, M., and Faaborg, J., 1999, Patterns of area-sensitivity in grassland-nesting birds: Conservation Biology, v. 13, p. 1,424-1,436.

Woodin, M.C., Littles, C.J., and Skoruppa, M.K., 2008, Land use patterns and historical changes in the status of the western burrowing owl in southern Texas: Bulletin of the Texas Ornithological Society, v. 41, p. 6-13.

Yarnell, R.W., Scott, D.M., Chimimba, C.T., and Metcalfe, D.J., 2007, Untangling the roles of fire, grazing and rainfall on small mammal communities in grassland ecosystems: Oecologia, v. 154, p. 387-402.

Zuckerberg, B., and Vickery, P.D., 2006, Effects of mowing and burning on shrubland and grassland birds on Nantucket Island, Massachusetts: Wilson Journal of Ornithology, v. 118 , p. 353-363. 
Appendixes 1-2 
Appendix 1. List of bird species (not all-inclusive) detected on U.S. Navy facilities in southern Texas, 2003-2008.

[CC, Naval Air Station-Corpus Christi; W, Naval Auxiliary Landing Field Waldron; K, Naval Air Station-Kingsville; OG, Naval Auxiliary Landing Field Orange Grove; E, Escondido Ranch; X, species detected]

\begin{tabular}{|c|c|c|c|c|c|c|}
\hline Taxa and common name & Species & CC & $\mathbf{W}$ & $\mathbf{K}$ & $\mathbf{O G}$ & $\mathbf{E}$ \\
\hline \multicolumn{7}{|l|}{ ANSERIFORMES } \\
\hline \multicolumn{7}{|l|}{ Anatidae } \\
\hline BLACK-BELLIED WHISTLING-DUCK & Dendrocygna autumnalis & $\mathrm{X}$ & $\mathrm{X}$ & $\mathrm{X}$ & & $\mathrm{X}$ \\
\hline GREATER WHITE-FRONTED GOOSE & Anser albifrons & & & & $\mathrm{X}$ & \\
\hline MOTTLED DUCK & Anas fulvigula & $\mathrm{X}$ & $X$ & & & $\mathrm{X}$ \\
\hline MALLARD (MEXICAN DUCK) & Anas platyrhynchos & & & & & $\mathrm{X}$ \\
\hline NORTHERN PINTAIL & Anas acuta & $\mathrm{X}$ & & & $\mathrm{X}$ & $\mathrm{X}$ \\
\hline NORTHERN SHOVELER & Anas clypeata & & & & & $\mathrm{X}$ \\
\hline GADWALL & Anas strepera & & & & & $\mathrm{X}$ \\
\hline AMERICAN WIGEON & Anas americana & & & & & $\mathrm{X}$ \\
\hline BLUE-WINGED TEAL & Anas discors & & & & $\mathrm{X}$ & $\mathrm{X}$ \\
\hline RING-NECKED DUCK & Aythya collaris & & & & & $\mathrm{X}$ \\
\hline REDHEAD & Aythya americana & $\mathrm{X}$ & & & & \\
\hline \multicolumn{7}{|l|}{ GALLIFORMES } \\
\hline \multicolumn{7}{|l|}{ Phasianidae } \\
\hline RING-NECKED PHEASANT & Phasianus colchicus & & & & & $\mathrm{X}$ \\
\hline \multicolumn{7}{|l|}{ Meleagrididae } \\
\hline WILD TURKEY & Meleagris gallopavo & & & & & $\mathrm{X}$ \\
\hline \multicolumn{7}{|l|}{ Odontophoridae } \\
\hline NORTHERN BOBWHITE & Colinus virginianus & & & $\mathrm{X}$ & $\mathrm{X}$ & $\mathrm{X}$ \\
\hline SCALED QUAIL & Callipepla squamata & & & & $\mathrm{X}$ & $\mathrm{X}$ \\
\hline \multicolumn{7}{|l|}{ PODICIPEDIFORMES } \\
\hline \multicolumn{7}{|l|}{ Podicipedidae } \\
\hline LEAST GREBE & Tachybaptus dominicus & & & $\mathrm{X}$ & $\mathrm{X}$ & $\mathrm{X}$ \\
\hline PIED-BILLED GREBE & Podilymbus podiceps & & & & $\mathrm{X}$ & $\mathrm{X}$ \\
\hline \multicolumn{7}{|l|}{ PELECANIFORMES } \\
\hline \multicolumn{7}{|l|}{ Pelecanidae } \\
\hline AMERICAN WHITE PELICAN & Pelecanus erythrorhynchos & & $\mathrm{X}$ & & & \\
\hline BROWN PELICAN & Pelecanus occidentalis & $\mathrm{X}$ & & & & \\
\hline \multicolumn{7}{|l|}{ Anhingidae } \\
\hline ANHINGA & Anhinga anhinga & & $\mathrm{X}$ & & & \\
\hline \multicolumn{7}{|l|}{ Phalacrocoracidae } \\
\hline NEOTROPIC CORMORANT & Phalacrocorax brasilianus & & $\mathrm{X}$ & $\mathrm{X}$ & & $\mathrm{X}$ \\
\hline DOUBLE-CRESTED CORMORANT & Phalacrocorax auritus & $\mathrm{X}$ & & & & $\mathrm{X}$ \\
\hline \multicolumn{7}{|l|}{ CICONIIFORMES } \\
\hline \multicolumn{7}{|l|}{ Ardeidae } \\
\hline REDDISH EGRET & Egretta rufescens & $\mathrm{X}$ & & & & \\
\hline TRICOLORED HERON & Egretta tricolor & & & & & $\mathrm{X}$ \\
\hline LITTLE BLUE HERON & Egretta caerulea & $\mathrm{X}$ & & & & $\mathrm{X}$ \\
\hline SNOWY EGRET & Egretta thula & $\mathrm{X}$ & $\mathrm{X}$ & $\mathrm{X}$ & & \\
\hline GREAT BLUE HERON & Ardea herodias & $\mathrm{X}$ & $\mathrm{X}$ & $\mathrm{X}$ & $\mathrm{X}$ & $\mathrm{X}$ \\
\hline GREAT EGRET & Ardea alba & $\mathrm{X}$ & & $\mathrm{X}$ & & $\mathrm{X}$ \\
\hline CATTLE EGRET & Bubulcus ibis & $\mathrm{X}$ & & & & $\mathrm{X}$ \\
\hline GREEN HERON & Butorides virescens & & & $\mathrm{X}$ & & \\
\hline YELLOW-CROWNED NIGHT-HERON & Nyctanassa violacea & $\mathrm{X}$ & & & & \\
\hline BLACK-CROWNED NIGHT-HERON & Nycticorax nycticorax & $\mathrm{X}$ & & & & \\
\hline
\end{tabular}


Appendix 1. List of bird species (not all-inclusive) detected on U.S. Navy facilities in southern Texas, 2003-2008. - Continued

[CC, Naval Air Station-Corpus Christi; W, Naval Auxiliary Landing Field Waldron; K, Naval Air Station-Kingsville; OG, Naval Auxiliary Landing Field Orange Grove; E, Escondido Ranch; X, species detected]

\begin{tabular}{|c|c|c|c|c|c|c|}
\hline Taxa and common name & Species & CC & w & $\mathbf{K}$ & OG & $\mathbf{E}$ \\
\hline \multicolumn{7}{|l|}{ Threskiornithidae } \\
\hline WHITE-FACED IBIS & Plegadis chihi & $\mathrm{X}$ & & & & \\
\hline WHITE IBIS & Eudocimus albus & $\mathrm{X}$ & & $\mathrm{X}$ & & $\mathrm{X}$ \\
\hline ROSEATE SPOONBILL & Platalea ajaja & $\mathrm{X}$ & & & & \\
\hline \multicolumn{7}{|l|}{ FALCONIFORMES } \\
\hline \multicolumn{7}{|l|}{ Cathartidae } \\
\hline TURKEY VULTURE & Cathartes aura & $\mathrm{X}$ & $\mathrm{X}$ & $\mathrm{X}$ & $\mathrm{X}$ & $\mathrm{X}$ \\
\hline BLACK VULTURE & Coragyps atratus & & $\mathrm{X}$ & $\mathrm{X}$ & $\mathrm{X}$ & $\mathrm{X}$ \\
\hline \multicolumn{7}{|l|}{ Accipitridae } \\
\hline WHITE-TAILED KITE & Elanus leucurus & & & $\mathrm{X}$ & $\mathrm{X}$ & $\mathrm{X}$ \\
\hline NORTHERN HARRIER & Circus cyaneus & & & $\mathrm{X}$ & $\mathrm{X}$ & $\mathrm{X}$ \\
\hline SHARP-SHINNED HAWK & Accipiter striatus & & & $\mathrm{X}$ & $\mathrm{X}$ & $\mathrm{X}$ \\
\hline COOPER'S HAWK & Accipiter cooperii & $\mathrm{X}$ & $\mathrm{X}$ & $\mathrm{X}$ & $\mathrm{X}$ & $\mathrm{X}$ \\
\hline HARRIS'S HAWK & Parabuteo unicinctus & & & $\mathrm{X}$ & $\mathrm{X}$ & $\mathrm{X}$ \\
\hline WHITE-TAILED HAWK & Buteo albicaudatus & $\mathrm{X}$ & $\mathrm{X}$ & $\mathrm{X}$ & $\mathrm{X}$ & $\mathrm{X}$ \\
\hline SWAINSON'S HAWK & Buteo swainsoni & & & $\mathrm{X}$ & $\mathrm{X}$ & $\mathrm{X}$ \\
\hline RED-TAILED HAWK & Buteo jamaicensis & $\mathrm{X}$ & $\mathrm{X}$ & $\mathrm{X}$ & $\mathrm{X}$ & $\mathrm{X}$ \\
\hline BROAD-WINGED HAWK & Buteo platypterus & & & & $\mathrm{X}$ & $\mathrm{X}$ \\
\hline OSPREY & Pandion haliaetus & $\mathrm{X}$ & $\mathrm{X}$ & & & \\
\hline \multicolumn{7}{|l|}{ Falconidae } \\
\hline CRESTED CARACARA & Caracara cheriway & $\mathrm{X}$ & $\mathrm{X}$ & $\mathrm{X}$ & $\mathrm{X}$ & $\mathrm{X}$ \\
\hline MERLIN & Falco columbarius & & & & $\mathrm{X}$ & \\
\hline PRAIRIE FALCON & Falco mexicanus & & & & & $\mathrm{X}$ \\
\hline PEREGRINE FALCON & Falco peregrinus & $\mathrm{X}$ & & & & \\
\hline AMERICAN KESTREL & Falco sparverius & $\mathrm{X}$ & $\mathrm{X}$ & $\mathrm{X}$ & $\mathrm{X}$ & $\mathrm{X}$ \\
\hline \multicolumn{7}{|l|}{ GRUIFORMES } \\
\hline \multicolumn{7}{|l|}{ Rallidae } \\
\hline SORA & Porzana carolina & & & $\mathrm{X}$ & $\mathrm{X}$ & $\mathrm{X}$ \\
\hline VIRGINIA RAIL & Rallus limicola & & & & & $\mathrm{X}$ \\
\hline COMMON MOORHEN & Gallinula chloropus & & & $\mathrm{X}$ & & \\
\hline AMERICAN COOT & Fulica americana & & & & $\mathrm{X}$ & $\mathrm{X}$ \\
\hline \multicolumn{7}{|l|}{ Gruidae } \\
\hline SANDHILL CRANE & Grus canadensis & $\mathrm{X}$ & $\mathrm{x}$ & & $\mathrm{X}$ & $\mathrm{X}$ \\
\hline \multicolumn{7}{|l|}{ CHARADRIIFORMES } \\
\hline \multicolumn{7}{|l|}{ Charadriidae } \\
\hline WILSON'S PLOVER & Charadrius wilsonia & $\mathrm{X}$ & & & & \\
\hline SEMIPALMATED PLOVER & Charadrius semipalmatus & $\mathrm{X}$ & & & & \\
\hline KILLDEER & Charadrius vociferus & $\mathrm{X}$ & $\mathrm{X}$ & $\mathrm{x}$ & $\mathrm{X}$ & $\mathrm{X}$ \\
\hline BLACK-BELLIED PLOVER & Pluvialis squatarola & $\mathrm{x}$ & & & & \\
\hline \multicolumn{7}{|l|}{ Recurvirostridae } \\
\hline BLACK-NECKED STILT & Himantopus mexicanus & $\mathrm{X}$ & & & & \\
\hline
\end{tabular}


Appendix 1. List of bird species (not all-inclusive) detected on U.S. Navy facilities in southern Texas, 2003-2008. - Continued [CC, Naval Air Station-Corpus Christi; W, Naval Auxiliary Landing Field Waldron; K, Naval Air Station-Kingsville; OG, Naval Auxiliary Landing Field Orange Grove; E, Escondido Ranch; X, species detected]

\begin{tabular}{|c|c|c|c|c|c|c|}
\hline Taxa and common name & Species & CC & w & K & OG & E \\
\hline \multicolumn{7}{|l|}{ Scolopacidae } \\
\hline SPOTTED SANDPIPER & Actitis macularius & $\mathrm{X}$ & & & & \\
\hline SOLITARY SANDPIPER & Tringa solitaria & & & & & $\mathrm{X}$ \\
\hline LESSER YELLOWLEGS & Tringa flavipes & $\mathrm{X}$ & $\mathrm{X}$ & $\mathrm{X}$ & & $\mathrm{X}$ \\
\hline GREATER YELLOWLEGS & Tringa melanoleuca & $\mathrm{X}$ & & & & $\mathrm{X}$ \\
\hline WILLET & Tringa semipalmata & $\mathrm{X}$ & & & & \\
\hline WESTERN SANDPIPER & Calidris mauri & $\mathrm{X}$ & & & & $\mathrm{X}$ \\
\hline SEMIPALMATED SANDPIPER & Calidris pusilla & $\mathrm{X}$ & & & & \\
\hline LEAST SANDPIPER & Calidris minutilla & $\mathrm{X}$ & & & & $\mathrm{X}$ \\
\hline RED KNOT & Calidris canutus & $\mathrm{X}$ & & & & \\
\hline SANDERLING & Calidris alba & $\mathrm{X}$ & & & & \\
\hline DUNLIN & Calidris alpina & $\mathrm{X}$ & & & & \\
\hline LONG-BILLED CURLEW & Numenius americanus & $\mathrm{X}$ & & $\mathrm{X}$ & $\mathrm{X}$ & \\
\hline MARBLED GODWIT & Limosa fedoa & $\mathrm{X}$ & & & & \\
\hline LONG-BILLED DOWITCHER & Limnodromus scolopaceus & $\mathrm{X}$ & & & & \\
\hline SHORT-BILLED DOWITCHER & Limnodromus griseus & $\mathrm{X}$ & & & & \\
\hline RUDDY TURNSTONE & Arenaria interpres & $\mathrm{X}$ & & & & \\
\hline WILSON’S SNIPE & Gallinago delicata & $\mathrm{X}$ & $\mathrm{X}$ & & & $\mathrm{X}$ \\
\hline \multicolumn{7}{|l|}{ Laridae } \\
\hline LEAST TERN & Sternula antillarum & $\mathrm{X}$ & $\mathrm{X}$ & & & \\
\hline SANDWICH TERN & Thalasseus sandvicensis & $\mathrm{X}$ & & & & \\
\hline ROYAL TERN & Thalasseus maximus & $\mathrm{X}$ & & & & \\
\hline RING-BILLED GULL & Larus delawarensis & $\mathrm{X}$ & & & & \\
\hline LAUGHING GULL & Larus atricilla & $\mathrm{X}$ & $\mathrm{X}$ & $\mathrm{X}$ & & \\
\hline BLACK SKIMMER & Rynchops niger & $\mathrm{X}$ & & & & \\
\hline \multicolumn{7}{|l|}{ COLUMBIFORMES } \\
\hline \multicolumn{7}{|l|}{ Columbidae } \\
\hline ROCK PIGEON & Columba livia & & & & & $\mathrm{X}$ \\
\hline WHITE-WINGED DOVE & Zenaida asiatica & & & $\mathrm{X}$ & & $\mathrm{X}$ \\
\hline MOURNING DOVE & Zenaida macroura & $\mathrm{X}$ & $\mathrm{X}$ & $\mathrm{X}$ & $\mathrm{X}$ & $\mathrm{X}$ \\
\hline WHITE-TIPPED DOVE & Leptotila verreauxi & & & $\mathrm{X}$ & & \\
\hline INCA DOVE & Columbina inca & $\mathrm{X}$ & & $\mathrm{X}$ & & $\mathrm{X}$ \\
\hline COMMON GROUND-DOVE & Columbina passerina & & & $\mathrm{X}$ & $\mathrm{X}$ & $\mathrm{X}$ \\
\hline EURASIAN COLLARED-DOVE & Streptopelia decaocto & $\mathrm{X}$ & & & & \\
\hline
\end{tabular}

\section{CUCULIFORMES}

Cuculidae

GROOVE-BILLED ANI

GREATER ROADRUNNER

YELLOW-BILLED CUCKOO
Crotophaga sulcirostris

Geococcyx californianus

Coccyzus americanus

$\begin{array}{llll} & & \mathrm{X} & \\ & \mathrm{X} & \mathrm{X} & \mathrm{X} \\ \mathrm{X} & \mathrm{X} & & \mathrm{X}\end{array}$

\section{STRIGIFORMES}

Tytonidae

BARN OWL

Strigidae

EASTERN SCREECH-OWL

GREAT HORNED OWL

BURROWING OWL

SHORT-EARED OWL
Tyto alba

Megascops asio

Bubo virginianus

Athene cunicularia

Asio flammeus
X X X

X

$\mathrm{X} \quad \mathrm{X}$

X $\quad \mathrm{X}$ 
Appendix 1. List of bird species (not all-inclusive) detected on U.S. Navy facilities in southern Texas, 2003-2008. - Continued

[CC, Naval Air Station-Corpus Christi; W, Naval Auxiliary Landing Field Waldron; K, Naval Air Station-Kingsville; OG, Naval Auxiliary Landing Field Orange Grove; E, Escondido Ranch; X, species detected]

\begin{tabular}{|c|c|c|c|c|c|c|}
\hline Taxa and common name & Species & CC & W & $\mathbf{K}$ & OG & $\mathbf{E}$ \\
\hline \multicolumn{7}{|l|}{ CAPRIMULGIFORMES } \\
\hline \multicolumn{7}{|l|}{ Caprimulgidae } \\
\hline COMMON POORWILL & Phalaenoptilus nuttallii & & & & & $\mathrm{X}$ \\
\hline COMMON PAURAQUE & Nyctidromus albicollis & & & $\mathrm{X}$ & & $\mathrm{X}$ \\
\hline COMMON NIGHTHAWK & Chordeiles minor & $\mathrm{X}$ & & $\mathrm{X}$ & & \\
\hline LESSER NIGHTHAWK & Chordeiles acutipennis & & & $\mathrm{X}$ & & $\mathrm{X}$ \\
\hline \multicolumn{7}{|l|}{ APODIFORMES } \\
\hline \multicolumn{7}{|l|}{ Apodidae } \\
\hline CHIMNEY SWIFT & Chaetura pelagica & $\mathrm{X}$ & $\mathrm{X}$ & $\mathrm{X}$ & & \\
\hline \multicolumn{7}{|l|}{ Trochilidae } \\
\hline RUBY-THROATED HUMMINGBIRD & Archilochus colubris & $\mathrm{X}$ & & & $\mathrm{X}$ & \\
\hline \multicolumn{7}{|l|}{ CORACIIFORMES } \\
\hline \multicolumn{7}{|l|}{ Alcedinidae } \\
\hline BELTED KINGFISHER & Megaceryle alcyon & $\mathrm{X}$ & & $\mathrm{X}$ & & \\
\hline \multicolumn{7}{|l|}{ PICIFORMES } \\
\hline \multicolumn{7}{|l|}{ Picidae } \\
\hline GOLDEN-FRONTED WOODPECKER & Melanerpes aurifrons & $\mathrm{X}$ & & $\mathrm{X}$ & $\mathrm{X}$ & $\mathrm{X}$ \\
\hline LADDER-BACKED WOODPECKER & Picoides scalaris & & & $\mathrm{X}$ & $\mathrm{X}$ & $\mathrm{X}$ \\
\hline \multicolumn{7}{|l|}{ PASSERIFORMES } \\
\hline \multicolumn{7}{|l|}{ Tyrannidae } \\
\hline COUCH'S KINGBIRD & Tyrannus couchii & $\mathrm{X}$ & & $\mathrm{X}$ & $\mathrm{X}$ & \\
\hline SCISSOR-TAILED FLYCATCHER & Tyrannus forficatus & $\mathrm{X}$ & $\mathrm{X}$ & $\mathrm{X}$ & $\mathrm{X}$ & $\mathrm{X}$ \\
\hline GREAT KISKADEE & Pitangus sulphuratus & $\mathrm{X}$ & & $\mathrm{X}$ & $\mathrm{X}$ & $\mathrm{X}$ \\
\hline GREAT CRESTED FLYCATCHER & Myiarchus crinitus & & & $\mathrm{X}$ & & \\
\hline BROWN-CRESTED FLYCATCHER & Myiarchus tyrannulus & & & $\mathrm{X}$ & & \\
\hline ASH-THROATED FLYCATCHER & Myiarchus cinerascens & & & $\mathrm{X}$ & & $\mathrm{X}$ \\
\hline EASTERN WOOD-PEWEE & Contopus virens & & & $\mathrm{X}$ & & \\
\hline BLACK PHOEBE & Sayornis nigricans & & & & & $\mathrm{X}$ \\
\hline EASTERN PHOEBE & Sayornis phoebe & $\mathrm{X}$ & & $\mathrm{X}$ & $\mathrm{X}$ & $\mathrm{X}$ \\
\hline SAY'S PHOEBE & Sayornis saya & & & & $\mathrm{X}$ & $\mathrm{X}$ \\
\hline VERMILION FLYCATCHER & Pyrocephalus rubinus & & & & & $\mathrm{X}$ \\
\hline \multicolumn{7}{|l|}{ Laniidae } \\
\hline LOGGERHEAD SHRIKE & Lanius ludovicianus & $\mathrm{X}$ & & $\mathrm{X}$ & $\mathrm{X}$ & $\mathrm{X}$ \\
\hline \multicolumn{7}{|l|}{ Vireonidae } \\
\hline BLUE-HEADED VIREO & Vireo solitarius & & & & $\mathrm{X}$ & \\
\hline WHITE-EYED VIREO & Vireo griseus & $\mathrm{X}$ & $\mathrm{X}$ & $\mathrm{X}$ & $\mathrm{X}$ & $\mathrm{X}$ \\
\hline BELL'S VIREO & Vireo bellii & & & $\mathrm{X}$ & & $\mathrm{X}$ \\
\hline WARBLING VIREO & Vireo gilvus & & & & & $\mathrm{X}$ \\
\hline \multicolumn{7}{|l|}{ Corvidae } \\
\hline GREEN JAY & Cyanocorax yncas & & & $\mathrm{X}$ & $\mathrm{X}$ & $\mathrm{X}$ \\
\hline CHIHUAHUAN RAVEN & Corvus cryptoleucus & & & & & $\mathrm{X}$ \\
\hline \multicolumn{7}{|l|}{ Alaudidae } \\
\hline HORNED LARK & Eremophila alpestris & & & $\mathrm{X}$ & $\mathrm{X}$ & \\
\hline
\end{tabular}


Appendix 1. List of bird species (not all-inclusive) detected on U.S. Navy facilities in southern Texas, 2003-2008. - Continued [CC, Naval Air Station-Corpus Christi; W, Naval Auxiliary Landing Field Waldron; K, Naval Air Station-Kingsville; OG, Naval Auxiliary Landing Field Orange Grove; E, Escondido Ranch; X, species detected]

\begin{tabular}{|c|c|c|c|c|c|c|}
\hline Taxa and common name & Species & CC & $\mathbf{w}$ & K & OG & E \\
\hline \multicolumn{7}{|l|}{ Hirundinidae } \\
\hline PURPLE MARTIN & Progne subis & & $\mathrm{X}$ & $\mathrm{X}$ & & $\mathrm{X}$ \\
\hline NO. ROUGH-WINGED SWALLOW & Stelgidopteryx serripennis & $\mathrm{X}$ & $\mathrm{X}$ & & & $\mathrm{X}$ \\
\hline BARN SWALLOW & Hirundo rustica & $\mathrm{X}$ & $\mathrm{X}$ & $\mathrm{X}$ & $\mathrm{X}$ & $\mathrm{X}$ \\
\hline CAVE SWALLOW & Petrochelidon fulva & $\mathrm{X}$ & $\mathrm{X}$ & $\mathrm{X}$ & $\mathrm{X}$ & $\mathrm{X}$ \\
\hline TREE SWALLOW & Tachycineta bicolor & & & & $\mathrm{X}$ & \\
\hline \multicolumn{7}{|l|}{ Paridae } \\
\hline BLACK-CRESTED TITMOUSE & Baeolophus atricristatus & & & & $\mathrm{X}$ & $\mathrm{X}$ \\
\hline \multicolumn{7}{|l|}{ Remizidae } \\
\hline VERDIN & Auriparus flaviceps & & & & $\mathrm{X}$ & $\mathrm{X}$ \\
\hline \multicolumn{7}{|l|}{ Troglodytidae } \\
\hline HOUSE WREN & Troglodytes aedon & $\mathrm{X}$ & $\mathrm{X}$ & & $\mathrm{X}$ & \\
\hline ROCK WREN & Salpinctes obsoletus & & & & & $\mathrm{X}$ \\
\hline SEDGE WREN & Cistothorus platensis & $\mathrm{X}$ & $\mathrm{X}$ & & $\mathrm{X}$ & $\mathrm{X}$ \\
\hline MARSH WREN & Cistothorus palustris & & & & $\mathrm{X}$ & \\
\hline CACTUS WREN & Campylorhynchus brunneicapillus & & & & & $\mathrm{X}$ \\
\hline BEWICK'S WREN & Thryomanes bewickii & & & $\mathrm{X}$ & $\mathrm{X}$ & $\mathrm{X}$ \\
\hline \multicolumn{7}{|l|}{ Regulidae } \\
\hline RUBY-CROWNED KINGLET & Regulus calendula & & & $\mathrm{X}$ & $\mathrm{X}$ & $\mathrm{X}$ \\
\hline \multicolumn{7}{|l|}{ Sylviidae } \\
\hline BLUE-GRAY GNATCATCHER & Polioptila caerulea & $\mathrm{X}$ & & & $\mathrm{X}$ & $\mathrm{X}$ \\
\hline BLACK-TAILED GNATCATCHER & Polioptila melanura & & & & $\mathrm{X}$ & $\mathrm{X}$ \\
\hline \multicolumn{7}{|l|}{ Turdidae } \\
\hline EASTERN BLUEBIRD & Sialia sialis & & & & $\mathrm{X}$ & \\
\hline AMERICAN ROBIN & Turdus migratorius & $\mathrm{X}$ & & & $\mathrm{X}$ & $\mathrm{X}$ \\
\hline \multicolumn{7}{|l|}{ Mimidae } \\
\hline NORTHERN MOCKINGBIRD & Miтus polyglottos & $\mathrm{X}$ & $\mathrm{X}$ & $\mathrm{X}$ & $\mathrm{X}$ & $\mathrm{X}$ \\
\hline GRAY CATBIRD & Dumetella carolinensis & & & & $\mathrm{X}$ & \\
\hline LONG-BILLED THRASHER & Toxostoma longirostre & & & $\mathrm{X}$ & $\mathrm{X}$ & $\mathrm{X}$ \\
\hline CURVE-BILLED THRASHER & Toxostoma curvirostre & & & $\mathrm{X}$ & & $\mathrm{X}$ \\
\hline \multicolumn{7}{|l|}{ Sturnidae } \\
\hline EUROPEAN STARLING & Sturnus vulgaris & $\mathrm{X}$ & & $\mathrm{X}$ & & $\mathrm{X}$ \\
\hline \multicolumn{7}{|l|}{ Motacillidae } \\
\hline SPRAGUE’S PIPIT & Anthus spragueii & $\mathrm{X}$ & $\mathrm{X}$ & $\mathrm{X}$ & $\mathrm{X}$ & $\mathrm{X}$ \\
\hline AMERICAN PIPIT & Anthus rubescens & & & & $\mathrm{X}$ & $\mathrm{X}$ \\
\hline \multicolumn{7}{|l|}{ Bombycillidae } \\
\hline CEDAR WAXWING & Bombycilla cedrorum & & & & & $\mathrm{X}$ \\
\hline \multicolumn{7}{|l|}{ Parulidae } \\
\hline BLUE-WINGED WARBLER & Vermivora pinus & & & $\mathrm{X}$ & & \\
\hline TENNESSEE WARBLER & Vermivora peregrina & & & $\mathrm{X}$ & & $\mathrm{X}$ \\
\hline ORANGE-CROWNED WARBLER & Vermivora celata & & & $\mathrm{X}$ & $\mathrm{X}$ & $\mathrm{X}$ \\
\hline CANADA WARBLER & Wilsonia canadensis & & & & & $\mathrm{X}$ \\
\hline YEL.-RUMPED (MYRTLE) WARBLER & Dendroica coronata & & $\mathrm{X}$ & & $\mathrm{X}$ & $\mathrm{X}$ \\
\hline YELLOW WARBLER & Dendroica petechia & & & & $\mathrm{X}$ & \\
\hline YELLOW-BREASTED CHAT & Icteria virens & & & $\mathrm{X}$ & & \\
\hline COMMON YELLOWTHROAT & Geothlypis trichas & & & & & $\mathrm{X}$ \\
\hline OVENBIRD & Seiurus aurocapilla & & & & $\mathrm{X}$ & \\
\hline AMERICAN REDSTART & Setophaga ruticilla & & & $\mathrm{X}$ & & \\
\hline
\end{tabular}


Appendix 1. List of bird species (not all-inclusive) detected on U.S. Navy facilities in southern Texas, 2003-2008. - Continued

[CC, Naval Air Station-Corpus Christi; W, Naval Auxiliary Landing Field Waldron; K, Naval Air Station-Kingsville; OG, Naval Auxiliary Landing Field Orange Grove; E, Escondido Ranch; X, species detected]

\begin{tabular}{|c|c|c|c|c|c|c|}
\hline Taxa and common name & Species & CC & $\mathbf{w}$ & K & OG & $\mathbf{E}$ \\
\hline \multicolumn{7}{|l|}{ Emberizidae } \\
\hline SPOTTED TOWHEE & Pipilo maculatus & & & & & $\mathrm{X}$ \\
\hline OLIVE SPARROW & Arremonops rufivirgatus & & & $\mathrm{X}$ & $\mathrm{X}$ & $\mathrm{X}$ \\
\hline GRASSHOPPER SPARROW & Ammodramus savannarum & $\mathrm{X}$ & $\mathrm{X}$ & & $\mathrm{X}$ & $\mathrm{X}$ \\
\hline LE CONTE’S SPARROW & Ammodramus leconteii & $\mathrm{X}$ & $\mathrm{X}$ & $\mathrm{X}$ & & $\mathrm{X}$ \\
\hline SAVANNAH SPARROW & Passerculus sandwichensis & $\mathrm{X}$ & $\mathrm{X}$ & $\mathrm{X}$ & $\mathrm{X}$ & $\mathrm{X}$ \\
\hline VESPER SPARROW & Pooecetes gramineus & & $\mathrm{X}$ & & $\mathrm{X}$ & $\mathrm{X}$ \\
\hline LARK SPARROW & Chondestes grammacus & $\mathrm{X}$ & & $\mathrm{X}$ & $\mathrm{X}$ & $\mathrm{X}$ \\
\hline BLACK-THROATED SPARROW & Amphispiza bilineata & & & & $\mathrm{X}$ & $\mathrm{X}$ \\
\hline CASSIN'S SPARROW & Aimophila cassinii & & & & $\mathrm{X}$ & $\mathrm{X}$ \\
\hline FIELD SPARROW & Spizella pusilla & & & & $\mathrm{X}$ & $\mathrm{X}$ \\
\hline CLAY-COLORED SPARROW & Spizella pallida & & & & & $\mathrm{X}$ \\
\hline CHIPPING SPARROW & Spizella passerina & & & & & $\mathrm{X}$ \\
\hline WHITE-CROWNED SPARROW & Zonotrichia leucophrys & & & & $\mathrm{X}$ & $\mathrm{X}$ \\
\hline LINCOLN'S SPARROW & Melospiza lincolnii & & & $\mathrm{X}$ & $\mathrm{X}$ & $\mathrm{X}$ \\
\hline SWAMP SPARROW & Melospiza georgiana & & & & $\mathrm{X}$ & \\
\hline \multicolumn{7}{|l|}{ Cardinalidae } \\
\hline PYRRHULOXIA & Cardinalis sinuatus & & & $\mathrm{X}$ & $\mathrm{X}$ & $\mathrm{X}$ \\
\hline NORTHERN CARDINAL & Cardinalis cardinalis & $\mathrm{X}$ & $\mathrm{X}$ & $\mathrm{X}$ & $\mathrm{X}$ & $\mathrm{X}$ \\
\hline BLUE GROSBEAK & Passerina caerulea & & & $\mathrm{X}$ & & \\
\hline INDIGO BUNTING & Passerina cyanea & $\mathrm{X}$ & & & & \\
\hline PAINTED BUNTING & Passerina ciris & $\mathrm{X}$ & & $\mathrm{X}$ & & $\mathrm{X}$ \\
\hline \multicolumn{7}{|l|}{ Icteridae } \\
\hline EASTERN MEADOWLARK & Sturnella magna & $\mathrm{X}$ & $\mathrm{X}$ & $\mathrm{X}$ & $\mathrm{X}$ & $\mathrm{X}$ \\
\hline WESTERN MEADOWLARK & Sturnella neglecta & $\mathrm{X}$ & & & $\mathrm{X}$ & $\mathrm{X}$ \\
\hline RED-WINGED BLACKBIRD & Agelaius phoeniceus & $\mathrm{X}$ & $\mathrm{X}$ & $\mathrm{X}$ & $\mathrm{X}$ & $\mathrm{X}$ \\
\hline BREWER'S BLACKBIRD & Euphagus cyanocephalus & & & & $\mathrm{X}$ & $\mathrm{X}$ \\
\hline GREAT-TAILED GRACKLE & Quiscalus mexicanus & $\mathrm{X}$ & $\mathrm{X}$ & $\mathrm{X}$ & $\mathrm{X}$ & $\mathrm{X}$ \\
\hline BROWN-HEADED COWBIRD & Molothrus ater & & & $\mathrm{X}$ & $\mathrm{X}$ & $\mathrm{X}$ \\
\hline BRONZED COWBIRD & Molothrus aeneus & & & $\mathrm{X}$ & & $\mathrm{X}$ \\
\hline AUDUBON'S ORIOLE & Icterus graduacauda & & & $\mathrm{X}$ & & $\mathrm{X}$ \\
\hline \multicolumn{7}{|l|}{ Fringillidae } \\
\hline AMERICAN GOLDFINCH & Carduelis tristis & & & & $\mathrm{X}$ & $\mathrm{X}$ \\
\hline HOUSE FINCH & Carpodacus mexicanus & & & & $\mathrm{X}$ & \\
\hline \multicolumn{7}{|l|}{ Passeridae } \\
\hline HOUSE SPARROW & Passer domesticus & $\mathrm{X}$ & $\mathrm{X}$ & & $\mathrm{X}$ & \\
\hline
\end{tabular}


Appendix 2. List of grasses (not all-inclusive) identified at U.S. Navy facilities in southern Texas, 2003-2008.

[CC, Naval Air Station-Corpus Christi; W, Naval Auxiliary Landing Field Waldron; K, Naval Air Station-Kingsville; OG, Naval Auxiliary Landing Field Orange Grove; E, Escondido Ranch; N, native; X, species detected; I, introduced]

\begin{tabular}{|c|c|c|c|c|c|c|c|}
\hline Common name & Species & Origin & CC & $\mathbf{W}$ & $\mathbf{K}$ & $\mathbf{O G}$ & $\mathbf{E}$ \\
\hline Big bluestem & Andropogon gerardii & $\mathrm{N}$ & $\mathrm{X}$ & $\mathrm{X}$ & & & \\
\hline Bushy bluestem & Andropogon glomeratus & $\mathrm{N}$ & $\mathrm{X}$ & $\mathrm{X}$ & & & \\
\hline Slimspike threeawn & Aristida longespica var. geniculata & $\mathrm{N}$ & $\mathrm{X}$ & $\mathrm{X}$ & & & \\
\hline Prairie threeawn & Aristida oligantha & $\mathrm{N}$ & & & & $\mathrm{X}$ & \\
\hline Fendler threeawn & Aristida purpurea var. longiseta & $\mathrm{N}$ & & & & $\mathrm{X}$ & $\mathrm{X}$ \\
\hline Purple threeawn & Aristida purpurea var. purpurea & $\mathrm{N}$ & & & & $X$ & $\mathrm{X}$ \\
\hline Giant reed & Arundo donax & I & $\mathrm{X}$ & & & & \\
\hline King Ranch bluestem & Bothriochloa ischaemum var. songarica & I & & $\mathrm{X}$ & $\mathrm{X}$ & $\mathrm{X}$ & \\
\hline Silver beardgrass & Bothriochloa laguroides torreyana & $\mathrm{N}$ & $\mathrm{X}$ & $X$ & $\mathrm{X}$ & $\mathrm{X}$ & $\mathrm{X}$ \\
\hline Sideoats grama & Bouteloua curtipendula & $\mathrm{N}$ & & & & $\mathrm{X}$ & \\
\hline Hairy grama & Bouteloua hirsuta & $\mathrm{N}$ & $\mathrm{X}$ & & & & \\
\hline Texas grama & Bouteloua rigidiseta & $\mathrm{N}$ & $\mathrm{X}$ & & $\mathrm{X}$ & $\mathrm{X}$ & $\mathrm{X}$ \\
\hline Red grama & Bouteloua trifida & $\mathrm{N}$ & & & & $\mathrm{X}$ & $\mathrm{X}$ \\
\hline Rescuegrass & Bromus catharticus & I & & & & $\mathrm{X}$ & \\
\hline Buffalograss & Buchloe dactyloides & $\mathrm{N}$ & & & & $\mathrm{X}$ & $\mathrm{X}$ \\
\hline Southern sandbur & Cenchrus echinatus & $\mathrm{N}$ & & & & $\mathrm{X}$ & $\mathrm{X}$ \\
\hline Coastal sandbur & Cenchrus spinifex & $\mathrm{N}$ & $\mathrm{X}$ & & & $\mathrm{X}$ & $\mathrm{X}$ \\
\hline Slimspike windmill grass & Chloris andropogonoides & $\mathrm{N}$ & $\mathrm{X}$ & & & & \\
\hline Fringed windmill grass & Chloris ciliata & $\mathrm{N}$ & & & & $\mathrm{X}$ & \\
\hline Hooded windmill grass & Chloris cucullata & $\mathrm{N}$ & $\mathrm{X}$ & & $\mathrm{X}$ & $\mathrm{X}$ & $\mathrm{X}$ \\
\hline Rhodes grass & Chloris gayana & I & & & $\mathrm{X}$ & & \\
\hline Shortspike windmill grass & Chloris subdolichostachya & $\mathrm{N}$ & $\mathrm{X}$ & & & & \\
\hline Tumble windmill grass & Chloris verticillata & $\mathrm{N}$ & $\mathrm{X}$ & & & $\mathrm{X}$ & \\
\hline Bermudagrass & Cynodon dactylon & I & & & & $\mathrm{X}$ & $\mathrm{X}$ \\
\hline Roundseed panicgrass & Dichanthelium sphaerocarpon & $\mathrm{N}$ & $\mathrm{X}$ & $\mathrm{X}$ & & & \\
\hline Kleberg bluestem & Dichanthium annulatum & I & $\mathrm{X}$ & $\mathrm{X}$ & $\mathrm{X}$ & $\mathrm{X}$ & $\mathrm{X}$ \\
\hline Angleton bluestem & Dichanthium aristatum & I & $\mathrm{X}$ & & & & $\mathrm{X}$ \\
\hline Silky bluestem & Dichanthium sericeum & I & $\mathrm{X}$ & & & $\mathrm{X}$ & $\mathrm{X}$ \\
\hline Fall witchgrass & Digitaria cognata & $\mathrm{N}$ & $\mathrm{X}$ & & & & $\mathrm{X}$ \\
\hline Saltgrass & Distichlis spicata & $\mathrm{N}$ & $\mathrm{X}$ & & & & \\
\hline Jungle rice & Echinochloa colona & I & & & $\mathrm{X}$ & & \\
\hline Pan American balsamscale & Elionurus tripsacoides & $\mathrm{N}$ & $\mathrm{X}$ & & & & \\
\hline Plains lovegrass & Eragrostis intermedia & $\mathrm{N}$ & & & & $\mathrm{X}$ & \\
\hline Red lovegrass & Eragrostis secundiflora oxylepis & $\mathrm{N}$ & $\mathrm{X}$ & $\mathrm{X}$ & & & \\
\hline Purple lovegrass & Eragrostis spectabilis & $\mathrm{N}$ & $\mathrm{X}$ & $\mathrm{X}$ & $\mathrm{X}$ & $\mathrm{X}$ & \\
\hline Louisiana cupgrass & Eriochloa punctata & $\mathrm{N}$ & & & & & $\mathrm{X}$ \\
\hline Hairy woollygrass & Erioneuron pilosum & $\mathrm{N}$ & & & & $\mathrm{X}$ & \\
\hline Pinewoods fingergrass & Eustachys petraea & $\mathrm{N}$ & $\mathrm{X}$ & $\mathrm{X}$ & & & \\
\hline
\end{tabular}


Appendix 2. List of grasses (not all-inclusive) identified at U.S. Navy facilities in southern Texas, 2003-2008. - Continued

[CC, Naval Air Station-Corpus Christi; W, Naval Auxiliary Landing Field Waldron; K, Naval Air Station-Kingsville; OG, Naval Auxiliary Landing Field Orange Grove; E, Escondido Ranch; N, native; X, species detected; I, introduced]

\begin{tabular}{|c|c|c|c|c|c|c|c|}
\hline Common name & Species & Origin & CC & W & K & $\mathbf{O G}$ & $\mathrm{E}$ \\
\hline Curly-mesquite & Hilaria belangeri & $\mathrm{N}$ & & & & & $\mathrm{X}$ \\
\hline Green sprangletop & Leptochloa dubia & $\mathrm{N}$ & & & & $\mathrm{X}$ & $\mathrm{X}$ \\
\hline Ozark grass & Limnodea arkansana & $\mathrm{N}$ & & & & $\mathrm{X}$ & \\
\hline Gulfhairawn muhly & Muhlenbergia filipes & $\mathrm{N}$ & $\mathrm{X}$ & $\mathrm{X}$ & & & \\
\hline Texas wintergrass & Nassella leucotricha & $\mathrm{N}$ & & & & $\mathrm{X}$ & \\
\hline Creeping lovegrass & Neeragrostis reptans & $\mathrm{N}$ & & & & $\mathrm{X}$ & $\mathrm{X}$ \\
\hline Kleingrass & Panicum coloratum & I & & & & $\mathrm{X}$ & $\mathrm{X}$ \\
\hline Hall's panicgrass & Panicum hallii & $\mathrm{N}$ & & & & & $\mathrm{X}$ \\
\hline Vine mesquite & Panicum obtusum & $\mathrm{N}$ & & & & & $\mathrm{X}$ \\
\hline Switchgrass & Panicum virgatum & $\mathrm{N}$ & $\mathrm{X}$ & $\mathrm{X}$ & & $\mathrm{X}$ & $\mathrm{X}$ \\
\hline Pink pappusgrass & Pappophorum bicolor & $\mathrm{N}$ & & & & $\mathrm{X}$ & $\mathrm{X}$ \\
\hline Whiplash pappusgrass & Pappophorum vaginatum & $\mathrm{N}$ & & & & & $\mathrm{X}$ \\
\hline Longtom & Paspalum denticulatum & $\mathrm{N}$ & $\mathrm{X}$ & & & & \\
\hline Gulfdune paspalum & Paspalum monostachyum & $\mathrm{N}$ & $\mathrm{X}$ & $\mathrm{X}$ & & & \\
\hline Thin paspalum & Paspalum setaceum & $\mathrm{N}$ & & $\mathrm{X}$ & & & \\
\hline Brownseed paspalum & Paspalum plicatulum & $\mathrm{N}$ & $\mathrm{X}$ & $\mathrm{X}$ & & & \\
\hline Hairyseed paspalum & Paspalum pubiflorum & $\mathrm{N}$ & & & & $\mathrm{X}$ & \\
\hline Buffelgrass & Pennisetum ciliare & I & $X$ & & $\mathrm{X}$ & $\mathrm{X}$ & $\mathrm{X}$ \\
\hline Seacoast bluestem & Schizachyrium littorale & $\mathrm{N}$ & $\mathrm{X}$ & $\mathrm{X}$ & & & \\
\hline Plains bristlegrass & Setaria leucopila & $\mathrm{N}$ & & & $\mathrm{X}$ & $\mathrm{X}$ & $\mathrm{X}$ \\
\hline Marsh bristlegrass & Setaria parviflora & $\mathrm{N}$ & $\mathrm{X}$ & & $\mathrm{X}$ & $\mathrm{x}$ & \\
\hline Indiangrass & Sorghastrum nutans & $\mathrm{N}$ & $\mathrm{X}$ & $\mathrm{X}$ & & & \\
\hline Johnsongrass & Sorghum halepense & I & $\mathrm{X}$ & & $\mathrm{X}$ & $\mathrm{X}$ & \\
\hline Gulf cordgrass & Spartina spartinae & $\mathrm{N}$ & $\mathrm{X}$ & & & & $\mathrm{X}$ \\
\hline Whorled dropseed & Sporobolus pyramidatus & $\mathrm{N}$ & & & & $\mathrm{X}$ & $\mathrm{X}$ \\
\hline Sand dropseed & Sporobolus cryptandrus & $\mathrm{N}$ & & & $\mathrm{X}$ & & $\mathrm{X}$ \\
\hline Smut grass & Sporobolus indicus & $\mathrm{N}$ & $\mathrm{X}$ & & & & \\
\hline Seashore dropseed & Sporobolus virginicus & $\mathrm{N}$ & $\mathrm{X}$ & & & & \\
\hline False Rhodes grass & Trichloris crinita & $\mathrm{N}$ & & & & & $\mathrm{X}$ \\
\hline White tridens & Tridens albescens & $\mathrm{N}$ & & & & & $\mathrm{X}$ \\
\hline Lovegrass tridens & Tridens eragrostoides & $\mathrm{N}$ & & & & $\mathrm{X}$ & \\
\hline Slim tridens & Tridens muticus var. muticus & $\mathrm{N}$ & & & & $\mathrm{X}$ & $\mathrm{X}$ \\
\hline Texas tridens & Tridens texanus & $\mathrm{N}$ & & & & $\mathrm{X}$ & \\
\hline Prairie false oat & Trisetum interruptum & $\mathrm{N}$ & & & & $\mathrm{X}$ & \\
\hline Browntop signalgrass & Urochloa fusca & $\mathrm{N}$ & $\mathrm{X}$ & & $\mathrm{X}$ & $\mathrm{X}$ & $\mathrm{X}$ \\
\hline Liverseed grass & Urochloa panicoides & I & $\mathrm{X}$ & & & $\mathrm{X}$ & $\mathrm{X}$ \\
\hline Texas signalgrass & Urochloa texana & $\mathrm{N}$ & & & & $\mathrm{X}$ & $\mathrm{X}$ \\
\hline Guineagrass & Urochloa maxima & $\mathrm{I}$ & $\mathrm{X}$ & & $\mathrm{X}$ & & $\mathrm{X}$ \\
\hline
\end{tabular}


Publishing support provided by: Rolla Publishing Service Center

For more information concerning this publication, contact: Director, USGS Columbia Environmental Research Center 4200 New Haven Road

Columbia, MO 65201

(573) 875-5399

Or visit the Columbia Environmental Research Center Web site at: http://www.cerc.usgs.gov 

